THE CHALLENGE OF PREDICTING CURRENCY CRISES: HOW DO

DEFINITION AND PROBABILITY THRESHOLD CHOICE MAKE A DIFFERENCE?

A Master's Thesis

by

AYŞEGÜL AYTAÇ

Department of

Economics

İhsan Doğramacı Bilkent University

Ankara

September 2015 
To my family and people who are as close to me as they are 
THE CHALLENGE OF PREDICTING CURRENCY CRISES: HOW DO DEFINITION AND PROBABILITY THRESHOLD CHOICE MAKE A DIFFERENCE?

\author{
Graduate School of Economics and Social Sciences \\ of \\ İhsan Doğramacı Bilkent University
}

by

\author{
AYŞEGÜL AYTAÇ \\ In Partial Fulfilment of the Requirements for the Degree of \\ MASTER OF ARTS \\ in \\ THE DEPARTMENT OF \\ ECONOMICS \\ İHSAN DOĞRAMACI BILKENT UNIVERSITY \\ ANKARA
}

September 2015 
I certify that I have read this thesis and have found that it is fully adequate, in scope and in quality, as a thesis for the degree of Master of Arts in Economics.

Assoc. Prof. Fatma Taşkın

Supervisor

I certify that I have read this thesis and have found that it is fully adequate, in scope and in quality, as a thesis for the degree of Master of Arts in Economics.

Assoc. Prof. Yeliz Yalçın

Examining Committee Member

I certify that I have read this thesis and have found that it is fully adequate, in scope and in quality, as a thesis for the degree of Master of Arts in Economics.

Asst. Prof. Ayşe Özgür Pehlivan

Examining Committee Member

Approval of the Graduate School of Economics and Social Sciences

Prof. Dr. Erdal Erel

Director 


\title{
ABSTRACT \\ THE CHALLENGE OF PREDICTING CURRENCY CRISES: HOW DO DEFINITION AND PROBABILITY THRESHOLD CHOICE MAKE A DIFFERENCE?
}

\author{
Aytaç, Ayşegül \\ M.A. in Economics \\ Supervisor: Assoc. Prof. Dr. Fatma Taşkın
}

September, 2015

The focus of this thesis is currency crisis, particularly the evaluation of the models that attempt to forecast currency crisis. Here, we aim to investigate the impacts of definition differences and probability threshold choices on Early Warning Systems.

In the first part of the thesis, in order to show that significances of the crisis indicators are dependent to crisis definitions of the models, we separately identify the significant variables for the models that are constructed with the depreciation based definition of Reinhart and Rogoff (2009) and Exchange Market Pressure Index based definition of Eichengreen et al. (1996).

In the second part, in order to analyze the definition effect on prediction powers of EWS models, by using 20 different versions of Reinhart and Rogoff (2009) and Eichengreen et al.'s (1996) currency definitions from the literature as dependent variables and the significant variables from the first part of our thesis as explanatory variables we construct 20 different EWS models. Furthermore, to analyze the probability threshold choice effect on prediction powers of the Early 
Warning System models, in this part we identify 11 different threshold levels and forecast our models 11 times for each of those threshold levels.

Our results show that crisis definitions and threshold choices significantly affect the prediction powers of the EWS models. To put it more explicitly, EMP index based definition is shown to be a better predictor compared to depreciation based definition. Furthermore, EMP index is found to give better results with higher standard deviation multiplier. Last but not least, it is empirically proven that $50 \%$ threshold is the optimal level for EWS analyses as until that level the prediction powers of the models significantly increase but keep constant above it.

Keywords: Currency Crisis, Early Warning System, Probability Threshold, Prediction Power 


\title{
ÖZET
}

\section{PARA KRIZLERININ TAHMINDEKI ZORLUK: KRIZ TANIMI VE TAHMIN EŞIĞİ NASIL FARK YARATIR?}

\author{
Aytaç, Ayşegül \\ Yüksek Lisans, Ekonomi Bölümü \\ Tez Yöneticisi: Doç. Dr. Fatma Taşkın
}

Eylül, 2015

Bu tez çalışması, para krizlerindeki tanım farklılıklarının ve tahmin eşiği seçiminin, krizlerin tahminleme gücü üzerindeki etkisini araştırmayı amaçlamaktadır.

Para krizleri literatürde iki farklı yöntem kullanılarak tanımlanmaktadır. Bunlardan birincisi ulusal paranın nominal değer yitirme oranını temel alınarak yapılan tanımlar, diğeri ise finansal baskı endeksi oluşturularak yapılan tanımlardır. Çalışmanın ilk kısmında, kriz tanımları buna göre iki gruba ayrılmış ve bu iki gruptan Reinhart ve Rogoff (2009) ve Eichengreen, Rose ve Wyplosz (1996) çalışmalarında kullanılan para krizi tanımları bağımlı değişken olarak kabul edilmiştir. Sonuç olarak kullanılan değişkenlerin anlamlılıklarının kriz tanımına göre farklılık sergilediği gösterilmiş ve her iki tanım grubu için ortak bir değişken kümesi elde edilmiştir. Çalışmanın diğer bölümünde tanım farklılıklarının ve tahmin eşiğinin tahminleme gücü üzerindeki etkisini saptamak amacı ile alternatif tanımlar eklenerek 20 farklı para krizi tanımı oluşturulmuş ve 11 farklı eşik değerinde analizleri 
gerçekleştirilmiştir. Tüm kriz tanımlarının analizinde Lojistik regresyon kullanılmakta ve veriler 1970-2010 yılları arasını kapsamaktadır.

Sonuç olarak, tahmin eşiğinin ve para krizlerindeki tanım farklılıklarının, tahminleme gücü üzerinde önemli etkisi olduğu sonucuna ulaşılmış ve \%50 tahmin eşiğinin tahmin gücü açısından optimal eşik değer olduğu ve bu eşikten sonra modellerin tahminleme gücünde bir değişiklik meydana gelmediği gösterilmiştir. Buna ek olarak, finansal baskı endeksi temel alınarak oluşturulan kriz tanımlarının, standart sapma değeri yükseldikçe tahminleme gücünün arttığı görülmüştür.

Anahtar Sözcükler: Para Krizleri, Erken Uyarı Sistemi, Tahmin Eşiği, Tahminleme Başarısı 


\section{ACKNOWLEDGEMENTS}

I would like to thank to my advisor Professor Fatma Taşkın for her support throughout the course of my thesis. I am also grateful to my examining committee members, Ayşe Özgür Pehlivan and Yeliz Yalçın for their helpful suggestions as an examining committee member.

I would like to express my deep-felt thanks to Prof. Dr. Ahmet Aksoy, for sharing his invaluable knowledge, experiences and time and guiding during my graduate study.

I owe my special thanks to my father, mother and sister who stood by me during every difficulty I faced throughout my study as they have done so throughout my life. Thank you for your unconditional love, support, patience and encouragement.

I am also thankful to Damla Şat and Aybüke Tüzmen for their continuous support, whom have supported me with hope, courage and fun and always kept my confidence high, as real sisters.

Finally, I owe my special thanks to Dogus Emin who supported me in every possible way during my study. He believed in me more than myself and made me know that, I will never walk alone anymore. I could never have done this without your support, patience and compassion. 


\section{TABLE OF CONTENTS}

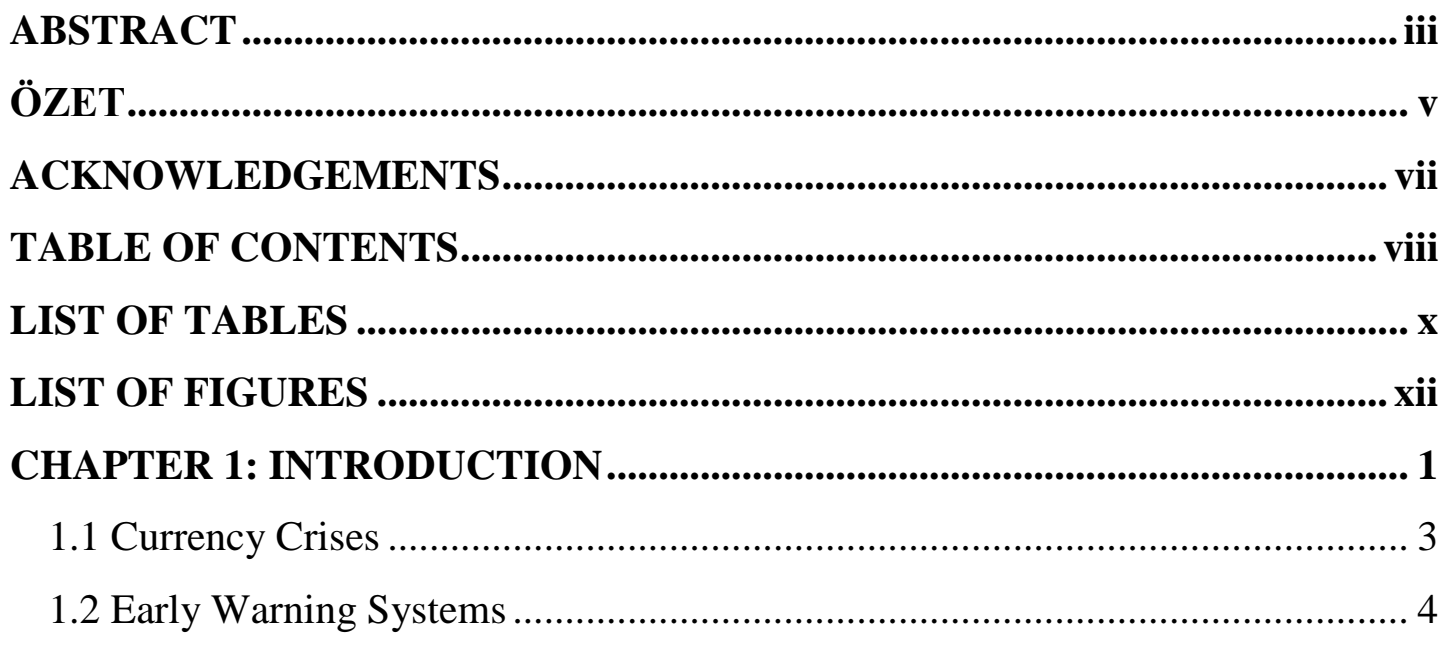

CHAPTER 2: ECONOMIC CRISES AND EARLY WARNING SYSTEMS ..... 7

2.1. Experience of Economic Crises ………....................................................... 7

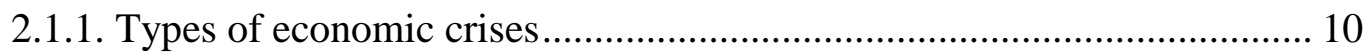

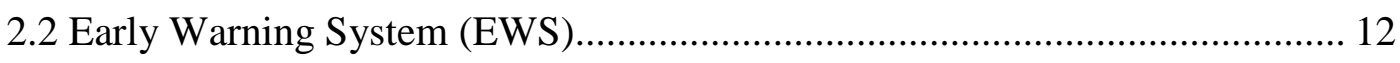

CHAPTER 3: LITERATURE REVIEW ............................................................. 18

3.1 Depreciation Rate Based Definitions ........................................................ 21

3.2 Exchange Market Pressure Index Based Definitions …................................. 22

3.3 Currency Crisis Prediction Success in the Literature ..................................... 26

CHAPTER 4: DATA AND METHODOLOGY ..................................................... 29

4.1 Data, Explanatory Variables, Time Period and Sample Countries ................. 29

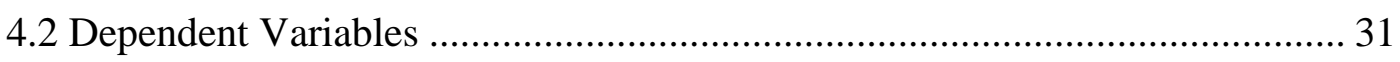

4.2.1 Depreciation Rate Based Currency Crisis Definition (Reinhart and Rogoff, 2009):

4.2.2 Exchange Market Pressure Index Based Currency Crisis Definition (Eichengreen et al., 1996):............................................................................. 33

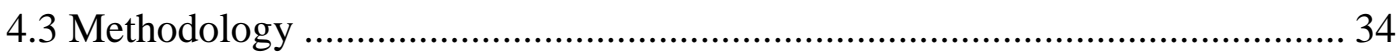




\section{CHAPTER 5: EMPIRICAL RESULTS OF CRISIS PROBABILITY}

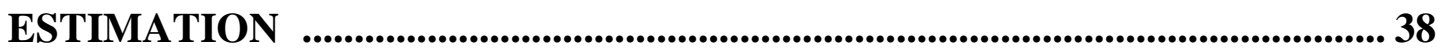

5.1 Nominal Exchange Rate Depreciation-Based Crisis Definition ...................... 40

5.2 Exchange Market Pressure Index-based Crisis Definition ............................... 43

CHAPTER 6: SUCCESS OF EWS MODEL UNDER ALTERNATIVE CRISIS DEFINITIONS AND PROBABILITY THRESHOLD CHOICES...................... 47

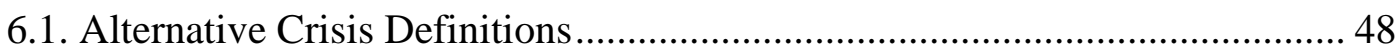

6.2 Prediction Power Results at 50\% Probability Threshold ............................... 54

6.3. Alternative Probability Thresholds …........................................................... 59

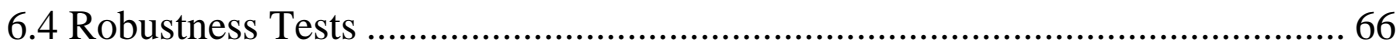

CHAPTER 7: THE ANALYSIS OF EWS PREDICTION ABILITY WITH OUT-OF-SAMPLE FORECAST ............................................................................ 70

7.1. Alternative Crisis Definitions .......................................................................... 70

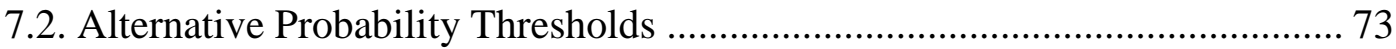

CHAPTER 8: CONCLUSION_......................................................................... 78

BIBLIOGRAPHY .............................................................................................. 82

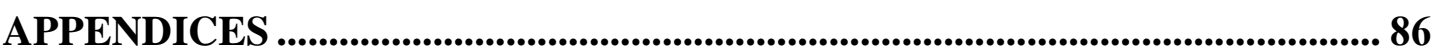

A.1. DEFINITIONS OF EXPLANATORY VARIABLES ….............................. 86

A2. CURRENCY CRISIS DEFINITIONS IN SELECTED LITERATURE ........ 93

A3. EMPIRICAL RESULTS OF THE ROBUSTNESS TESTS ......................... 99

A4. PREDICTION POWER RESULTS OF THE ROBUSTNESS TESTS ........ 103

A5. EMPIRICAL RESULTS OF THE OUT-OF-SAMPLE ANALYSIS ........... 106 


\section{LIST OF TABLES}

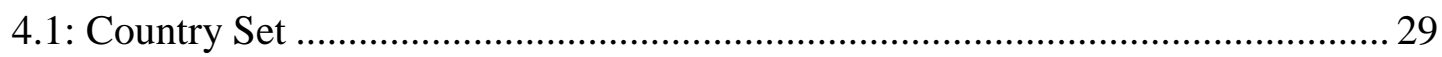

4.2: Explanatory Variable Categories and the List of Variables................................. 30

5.1: Empirical Results of the Models that constructed with Reinhart and Rogoff

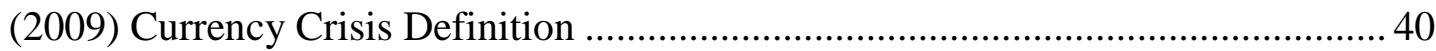

5.2: Empirical Results for the Models according to Eichengreen et al. (1996)

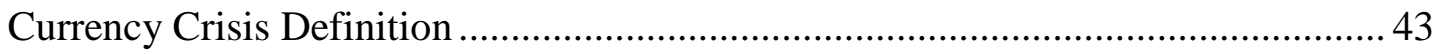

6.1: Depreciation Rate Based Currency Crisis Definitions....................................... 50

6.2: Exchange Market Pressure Index Based Currency Crisis Definitions with

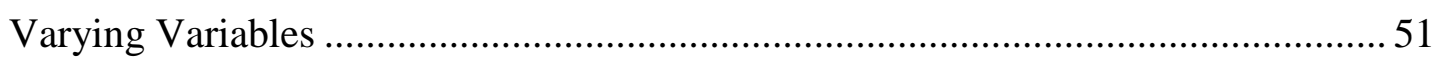

6.3: Exchange Market Pressure Index Based Currency Crisis Definitions with Varying Standard Deviation Multiplier: ............................................................... 51

6.4: Prediction Powers according to Definitions, An Example for 50\% Probability Threshold Value

6.5: Type 1 Errors the Model according to different Crisis Definitions and different Probability Thresholds 60

6.6: Type 2 Errors the Model according to different Crisis Definitions and different Probability Thresholds 61

6.7: Prediction Powers of the Model according to different Crisis Definitions and different Probability Thresholds

7.1: Out-of-Sample Results of the Model according to different Currency Crisis Definitions.

7.2: Out-of-Sample Results of the Model according to different Currency Crisis

Definitions and Probability Threshold Values 74

A2.1: Currency Crisis Definitions in Selected Literature .93

A3.1: Regressions with Exports of Goods and Services (Annual \% Growth)..... 99 
A3.2: Regressions with the Ratio of Foreign Direct Investments to GDP. 100

A3.3: Regressions with Portfolio Equity Net Inflows (BoP, Current US\$) 101

A4.1: Robustness Test Results at 50\% Probability Threshold According to Currency Crisis Definitions, Exports of Goods and Services (Annual \% Growth) 103 A4.2: Robustness Test Results at 50\% Probability Threshold According to Currency Crisis Definitions, The Ratio of Foreign Direct Investments to GDP 104 A4.3: Robustness Test Results at 50\% Probability Threshold According to Currency Crisis Definitions, Portfolio Equity Net Inflows. 105

A5.1: Empirical Results of the Out-of-Sample Analysis 105 A5.2: Type 1 Errors the Model according to different Crisis Definitions and different Probability Thresholds, Out of Sample Results, Out of Sample.

A5.3:Type 2 Errors the Model according to different Crisis Definitions and different Probability Thresholds, Out of Sample Results, Out of Sample 


\section{LIST OF FIGURES}

1.1: Total Number of Currency Crises, Banking Crises and Sovereign Debt Crises

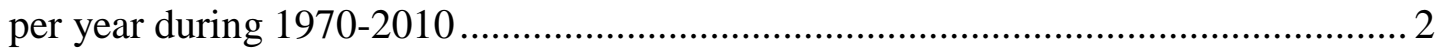

2.1: Depreciation Rates of World Currencies Since 1800s .......................................... 8

2.2: The annual GDP growths of Korea, Malaysia, Singapore, Thailand, Russia and

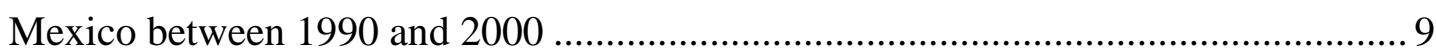

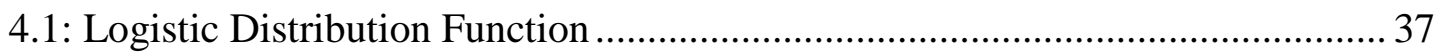

6.1: Average Prediction Powers and Probability Threshold Values for Definition

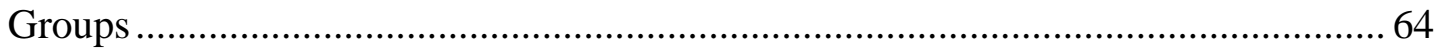

7.1: Out-of-Sample Results for Prediction Powers according to the Definition Groups .75 


\section{CHAPTER 1}

\section{INTRODUCTION}

Throughout the history, the economies of many countries have suffered from numerous economic crises at various times. According to Sachs et al.(1996), especially emerging countries are prone to economic crises for reasons such as international financial shocks, mismanagement of exchange rate system, financial irregularities and financial liberalization. The frequency and severity of these economic crises have dramatically increased since the collapse of the Bretton Woods system in the early 1970s. Most particularly in 1990s both developed and emerging countries experienced serious economic crises that created destructive consequences. Those crises caused loss of national public and personal wealth, and contributed to political uncertainty and shook the foundations of national, regional, international economic and social order (Reed, 1998).

Not all economic crises are the same. In their study, Reinhart and Ragoff (2009) empirically show that three types of crises are more common; currency crises, banking crises and sovereign debt crises. In Figure 1.1, total number of these three types of crises for the period 1970-2010 is shown for each year. According to this figure, during these years, world markets experienced 446 banking crises, 459 sovereign debt crises and 578 currency crises. 


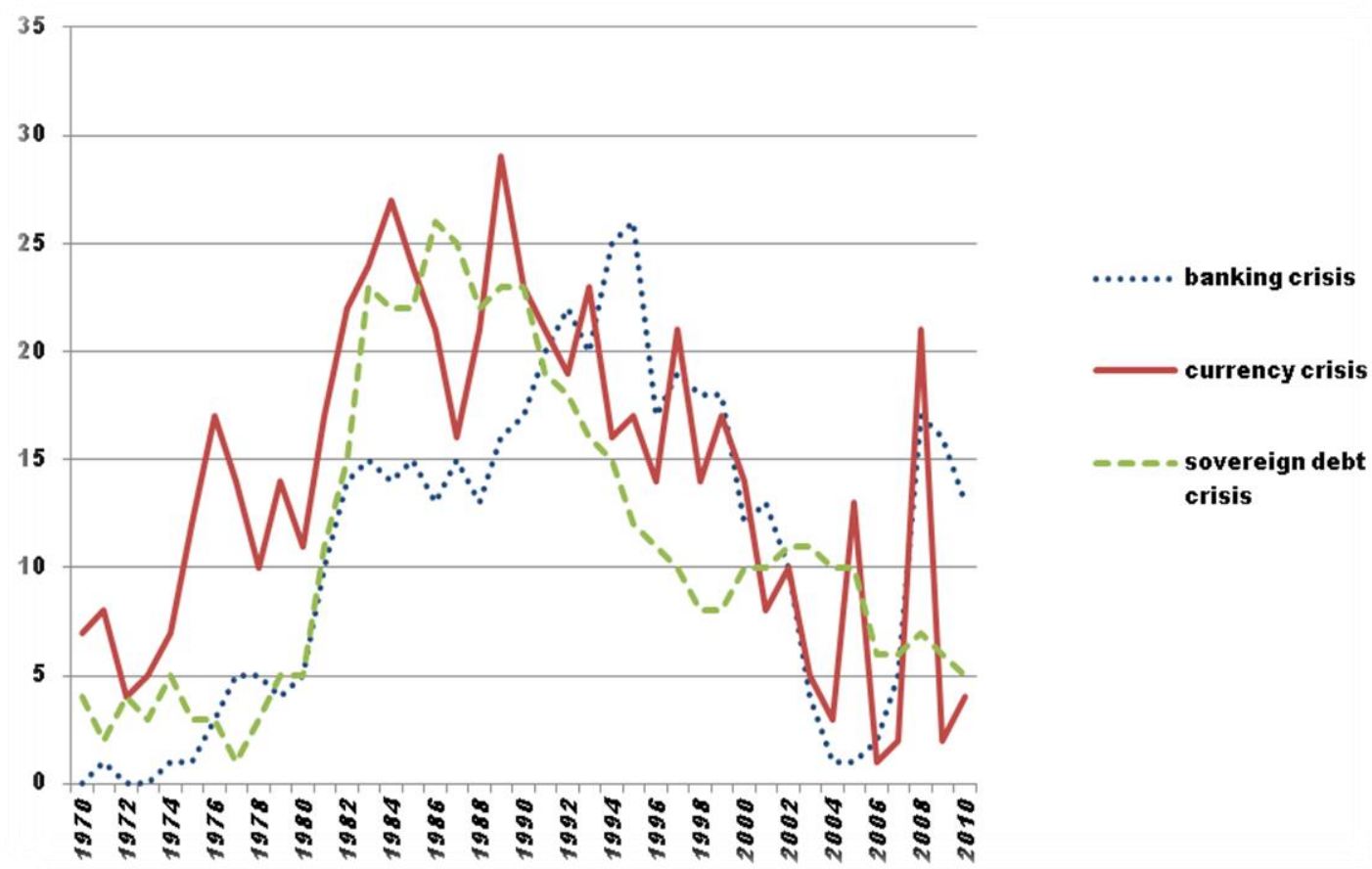

\section{Figure 1.1: Total Number of Currency Crises, Banking Crises and Sovereign Debt Crises per year during 1970-2010 ${ }^{1}$}

The figure illustrates that the number of currency crises are unambiguously more than both banking crises and sovereign debt crises. According to this, $40 \%$ of the experienced crises from 1970 to 2010 are currency crises. In the following section we briefly introduce the concept of currency crisis.

\subsection{Currency Crises}

The theoretical literature defines currency crisis for fixed exchange rate regimes and describes currency crisis as an official devaluation or a floatation of the currency. Floating currencies "might be subject to disruptive depreciation due to speculative attack" (Vlaar, 1999: 253) and for the freely floating currencies currency crises may

\footnotetext{
${ }^{1}$ The graph is prepared with the dataset of Reinhart and Rogoff (2009) which covers 69 countries. See Table 4.1 for the full list of countries.
} 
also occur. Therefore, today many empirical studies define a currency crisis as a large depreciation of the currency. However, the answer for the question 'what is large for a depreciation rate' is subjective as different studies accept different depreciation rates as critical levels. In the next chapter, we give more detail on how scholars quantitatively define the currency crises.

The focus of the thesis is currency crisis, particularly the evaluation of the models that attempt to forecast currency crisis. The reasons for this emphasis as follows: First, a substantial number of all economic crises that world markets experienced in history occurred in the form of currency crisis. The recent examples in the last two decades are 1992-1993 Crisis of European Exchange Rate Mechanism, 1994-1995 Latin American Crisis, 1997 Asian Crisis, 1998 Russian Default and Brazilian Crises, 2000-2001 Turkish and Argentinian Crises. Second, especially after 1990's the number of currency crises has increased dramatically while affecting a large number of countries either directly or indirectly and caused high level of unemployment, excessive output loss and GDP reductions. Finally, currency crises are generally the first and the most visible sign of serious macroeconomic and balance of payments imbalances and are very often associated with banking and sovereign crises (Frost and Saiki, 2013).

\subsection{Early Warning Systems}

In today's global environment, policymakers concede the fact that economic crisis is a natural element of the economies. Besides that, economies cannot avoid an upcoming crisis in an integrated world economy with strong contagion effect. For this reason, taking early precautions become crucial for the nations and their economies. 
Early Warning Systems (EWS) is an important tool to detect underlying economic weaknesses and vulnerabilities and to anticipate whether and when countries may be affected by an economic crisis. Edison (2000) defines an Early Warning System as a mechanism that uses a precise definition of a crisis to generate predictions of crises. The design of Early Warning Systems has some crucial properties; the definition of a crisis, the choice of explanatory variables, the choice of threshold and the estimation method (signal approach or limited dependent regression approach $)^{2}$. As different researchers adopt different approaches to address conceptual and practical issues (different crisis definitions, explanatory variables and/or threshold choices), the success rates of Early Warning Systems vary significantly from model to model ${ }^{3}$.

In the issue of currency crisis Early Warning Systems have been an important part of empirical literature. Existing literature focuses primarily on prediction of crisis indicators and generation of a model that identifies the correct crisis episodes. Those studies mostly test how additional indicators and different econometric models change the success rates. However, we believe that digging the crisis prediction phenomena deeper and showing the impacts of 'crisis definition' and 'threshold choices' on the models as crucial as creating a successful model.

In this thesis, we first examine how a currency crisis is defined. We include both the currency crisis definitions by solely concentrating on the rate of depreciation of domestic currency and the other method of using an index of Exchange Market Pressure which is a summary index of a group of macroeconomic variables that are indicators of a possible depreciation of domestic currency.

\footnotetext{
${ }^{2}$ The detailed explanation of the properties of Early Warning Systems is given in Chapter 2.

${ }^{3}$ In the literature part, we summarize the empirical studies that have different choices on these properties and describe how the Early Warning Systems models' success rate varies.
} 
In the context of the probability thresholds, all previous studies determine one or two probability threshold levels and conclude that the prediction power is not sensitive to probability threshold values. In this thesis, in order to examine whether this argument is true or not, we would like to evaluate how predictive power of EWS models change according to different threshold values.

Prior to the assessment of the predictive power of the models, our first step is to determine the explanatory factors of the crisis. In our study, we identify the significant variables among a list of real sector, financial sector and balance of payments variables, and debt profile of economies used in the sample. In these estimations we use two alternative crisis indicators. First one is the depreciation based definition of Reinhart and Rogoff (2009) and the second one is Exchange Market Pressure index based definition of Eichengreen et al. (1996). In this first step, we aim to identify the factors that determine crisis probability no matter how crisis is defined. By showing that each of those prominent crisis definition approach depends on a different explanatory variable sets, we contribute to the literature.

Then, we follow with assessment of EWS predictive ability. The prediction powers of EWS depend on how successful the model is on matching the real life crisis periods with the defined crisis. Here the purpose is to determine which crisis indicators and what level of threshold produce the best predictive model for a currency crisis. Therefore, in the second stage of our study, we hope to fill a gap in the literature by using various crisis definitions with various threshold levels for the same explanatory variables set.

In a summary, our study empirically shows the impacts of crisis definitions and threshold choices on the success in predicting currency crisis. 
Our study is particularly important for the economic crisis literature as our results prove that to be able to create the 'perfect' model that gives high success rates and identifies the crisis indicators correctly, each phase of the Early Warning System -from crisis definition to threshold choice, from explanatory variables choice to estimation method decision- should be considered all together.

This thesis is organized as follows: Chapter 2 explains the concept of economic crisis and Early Warning Systems. In Chapter 3, a comprehensive literature survey is presented which is elaborated on Early Warning Systems that focus on currency crises. In chapter 4, data, methodology and definitions of the currency crisis are explained. In Chapter 5, the empirical results of the models for currency crisis probability are presented. In Chapter 6, in-sample prediction power of the EWS models under alternative currency crisis definitions and threshold choices are discussed. The chapter also concludes some robustness tests on prediction power of the model for changes in explanatory variables. In Chapter 7, out of sample results are exhibited where the estimation result is chosen. Finally, Chapter 8 summarizes the whole study and concludes it. 


\section{CHAPTER 2}

\section{ECONOMIC CRISES AND EARLY WARNING SYSTEMS}

In this chapter, in the first part, we summarize the experience of economic crises in the world through the history. In the second part, we introduce the concept of Early Warning Systems as it constitutes the core of our thesis.

\subsection{Experience of Economic Crises}

Economic crises are seen as a rule rather than an exception (Bordo et al., 2001). As not being a new issue, they have been a common phenomenon since 1800 s with the development of money and financial markets (Reinhart and Rogoff, 2009). In the context of currency crisis, however, it is seen that there is an increase over the past century.

Figure 2.1 depicts the five year moving average of the depreciation rates of the world currencies between 1800 and 2010. The figure shows explicitly that currency crises date back to 1800s. It is observed that during the Napoleonic wars, the Great Depression and 1980s and 1990s, there are large and clustered peaks of turbulence (Brakman et al., 2013). 


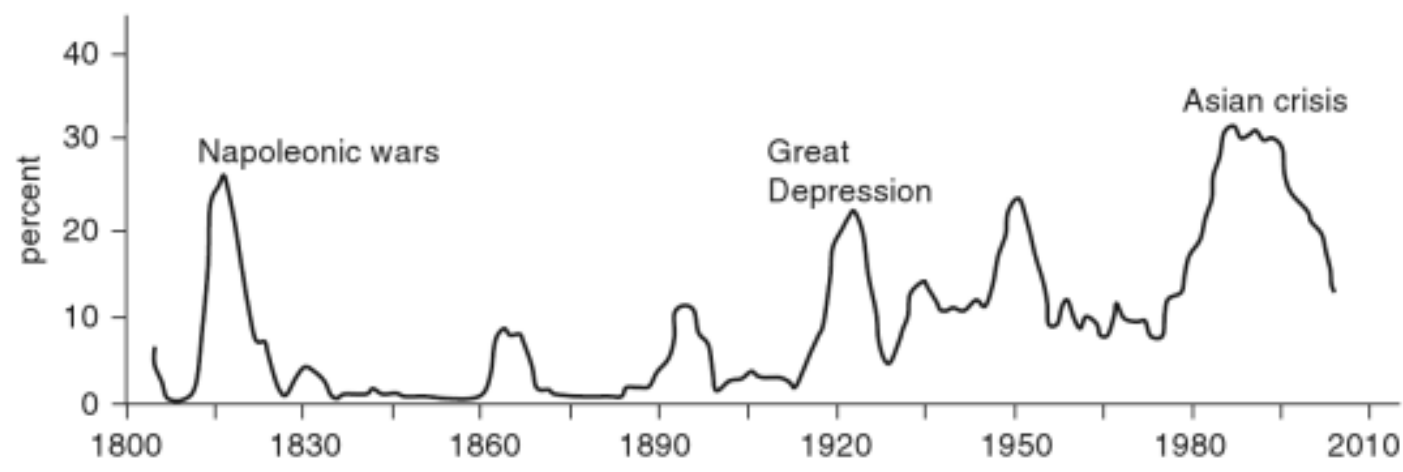

Figure 2.1: Depreciation Rates of World Currencies Since 1800s ${ }^{4}$

When the time period 1970 to early 2000s are examined, when there are large numbers of currency crisis, it is seen that various countries which resemble in some aspects or completely disparate from each other, experience and suffer from currency crises. Especially, 1990's, witnessed a considerable amount of currency crises such as near breakdown of European Exchange Rate Mechanism in 1992-1993, Mexican's Peso Crisis which is followed by Latin American Tequila Crisis in 1994-1995 and Asian Crisis in 1997-1998 (Pesenti and Tille, 2000).

As a matter of fact, it can be said that the simultaneous experience of a series of currency crisis was experienced in East Asia during 1997-1998 is one of the best examples of "contagion". During this period, following the devaluation of the Thai Baht, the currencies of Korea, Malaysia, Indonesia, Philippines and Singapore were rapidly devaluated. The annual GDP decline in Thailand and Malaysia was close to $10 \%$. This currency turmoil caused Indonesia's GDP to decline by $15 \%$ in a single year. Following this destructive crisis and due to its contagious nature Brazil and Russia were exposed to currency crisis as well in 1998-1999 and 1998 respectively 5 .

\footnotetext{
${ }^{4}$ The Source: Reinhart and Rogoff (2009)

${ }^{5}$ Contagion is the situations in which a crisis in one country causes crisis in other countries or at least makes them more likely (Mendoza and Quadrini, 2009).
} 
Bordo et al. (2001) state that currency crises can be very costly. These costs include fiscal and quasi-fiscal costs, misallocation and an underutilization of resources, losses in real output and changes in distribution of wealth. They estimate that the downturns following financial crises have lasted on average 2-3 years and cost 5- $10 \%$ of GDP (Bordo et al., 2001). Also during a severe currency crisis, the emerging economies suffer $8 \%$ cumulative loss in real output on average (Castillo, 2006). To elaborate the loss in output, Figure 2.2 shows the annual GDP growths crisis countries such as Thailand, Singapore, Malaysia, Korea and Russia between 1990 and 2000.
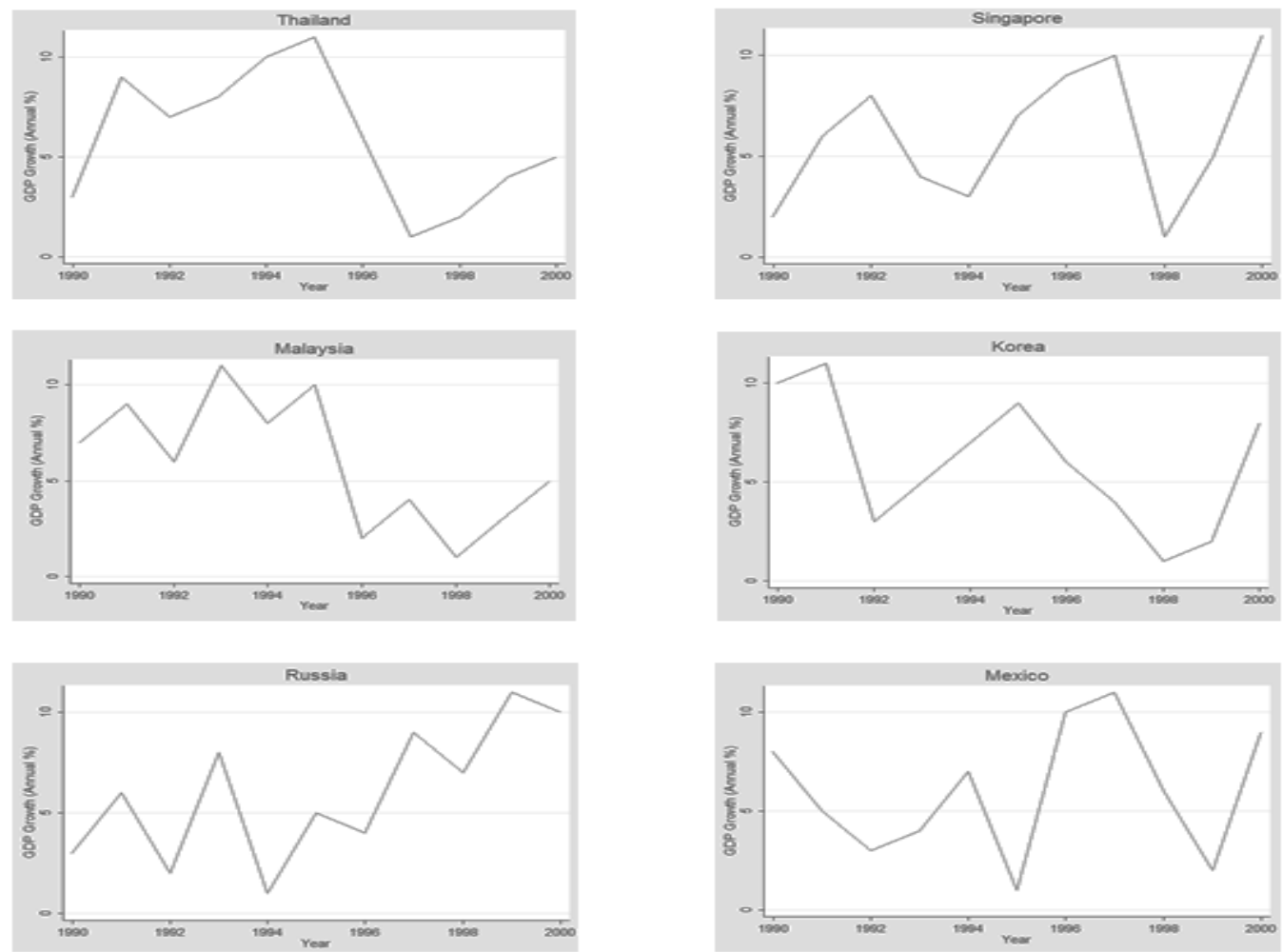

Figure 2.2: The annual GDP growths of Korea, Malaysia, Singapore, Thailand, Russia and Mexico between 1990 and $2000^{6}$

\footnotetext{
${ }^{6}$ The data for the graphs in Figure 2.2 is collected from World Bank Database.
} 


\subsubsection{Types of economic crises}

As we mentioned in the introduction chapter, not all economic crises are the same. There are 3 fundamental types of economic crisis. These are currency crisis, banking crisis and sovereign debt crisis. We will give brief introduction to these different types of crisis.

Currency Crises: As it is mentioned briefly in the previous chapter, among all types of economic crisis, currency crisis come to the forefront due to its frequency and destructive impacts on economies. Currency crisis can be defined as a speculative attack on the foreign exchange value of a currency which results in a sharp depreciation or forces the authorities to defend the currency by selling foreign exchange reserves or raising domestic interest rates (Glick, 2011).

Currency crises are generally the first and most visible sign of serious macroeconomic and balance of payments imbalances. They are very often associated with banking and sovereign crises. Moreover, the sudden adjustment of relative prices often leads to significant losses on public and private balance sheets. A currency crisis is typically followed by a substantial growth slow-down or a contraction (Frost and Saiki, 2013).

Banking Crises: A banking crisis occurs when actual or potential bank runs or failures induce banks to the internal convertibility of their liabilities or force the government to intervene to prevent this by providing banks with large scale financial support (Claessens and Kose, 2013). Banking crises come to the forefront of economies in the mid-1980s. Situations of banking distress have quickly multiplied becoming one of the main obstacles to exchange rate stability and magnifying the severity of currency crashes (Kaminsky, 2000). 
Banking crises have some significant direct and indirect costs. According to Caprio and Klingebiel (1996), during the banking crises average bailout cost is $10 \%$ of GDP and in some cases it can be much more costly. For instance; the Mexican Tequila Crisis (1994) cost 20\% of GDP whilst the Jamaican crisis (1996) cost 37\% of GDP.

Sovereign Debt Crises: According to Ciarlone and Trebeschi (2006), debt crisis may be "the whole range of forms that a debt crisis can take: outright defaults, potential defaults avoided only thanks to a restructuring/rescheduling of external debt or to the interventions by the IFIs, mounting debt-servicing difficulties, possibly leading to a missed payment on the country's external obligations or the accumulation of interest and/or principal arrears" (Ciarlone and Trebeschi, 2006, $\mathrm{p}: 10)$.

Debt crises are said to be positively correlated with currency crisis due to common causes such as negative shock on GDP growth which reduces the government's tax base and the international contagion effects. The internal contagion effect can be explained with the following logic. According to Bauer et al. (2005) devaluation can directly trigger a debt crisis as it increases the real value of foreign currency denominated debt or as it leads to credit rating downgrades (increase on the country's interest rate risk premium).

Most often many different crisis types occur together; such as currency crisis and banking crisis or currency crisis with debt crisis. Here, the focus of the thesis is currency crisis and success of the models that try to predict currency crisis, particularly Early Warning Systems.

Numerous studies reveal that economic crises have economic and social costs such as output lost, higher inflation, higher unemployment, lower real wages and 
negative fiscal implications of higher debt burden (Baszkiewicz and Paczyñski, 2001). Their major cost leads to a desire to predict economic crises. Academics, in addition to explaining the crisis phenomena, put a lot of effort in coming up with methods to predict the economic crises. Early Warning Systems aim to anticipate whether and when individual countries may be affected by an economic crisis. Those systems allow policymakers to detect underlying economic weaknesses and vulnerabilities and give them the possibility to take precautions in order to reduce a possible crisis (Bussière and Fratzscher, 2002). Therefore, the motivation behind the EWS models is to predict the possible future crisis and to monitor the crisis risk for countries. Early Warning Systems are explained in detail in following section.

\subsection{Early Warning System (EWS)}

Wide ranges of currency crisis have shown that currency crises are epidemic and have contagious effect. In this kind of situation, in order to overcome an incoming crisis, the best option would be having a mechanism to foresee the possible future crisis and to take early precautions. Today, academics and wide range of practitioners believe that this can be achieved by constructing a solid Early Warning System (EWS).

Academics, policy makers and economists seek for a model that gives the best prediction power of a possible future crisis. Therefore, today there is a wide range of studies that use different techniques, time periods, indicators and countries. Having said that, in the empirical literature of currency crisis, it is seen that there are two prominent approaches to develop a solid Early Warning System model.

- The Signal Approach 
The signal approach, which is pioneered by Kaminsky, Lizondo and Reinhart (KLR) (1998) and further improved by Edison (2000), is frequently applied in univariate models that involve monitoring a set of high-frequency leading indicators. It is reported that the indicators would behave differently prior to a financial crisis until they reach their individual threshold values (Cheang, 2008). If indicators exceed these threshold values, then it is considered as a crisis signal. It means that, when one of these variables deviates from its normal level beyond a certain threshold, then it is considered as a warning signal about a possible currency crisis within next 12-24 months (KLR, 1998).

The powerful feature of the signal approach is, it provides an opportunity to use a wide range of indicators. Furthermore, it enables to see each indicator's prediction powers while abnormal behaving variables can be indicated easily. As for other approaches, signal approach too has some drawbacks. It omits the relationship between the indicators and it cannot provide any information about how much each indicator exceeds its threshold value.

\section{- The Limited Dependent Regression Approach}

Limited Dependent Regression method is based on the observations of the key economic variables in order to estimate the probability of a crisis. Limited Dependent Regression is a parametric and regression based approach that using binary models with non-linear logit/probit function estimation and requires a construction of a crisis dummy variable that serves as the dependent variable in the regression (Ito and Orii, 2009).

This approach gives an opportunity to observe whether the explanatory variables have a predictive power on the estimation of possible future crisis. While this regression-based method allows us to test the statistical significance of the 
chosen explanatory variables all together, it also lets us to observe the marginal contribution of each indicator (Frankel and Rose, 1996). Moreover, as the method considers the significance of all variables simultaneously, the additional information of the new variables can be easily determined. However, in this approach the impact of an individual variable is not easy to be detected. Because of the non-linear logit/probit function, the contribution of a particular variable also depends on all the other variables and their values, which is a disadvantage of this approach (Vlaar, 1999).

In this Early Warning System method, crisis variable is a dependent variable, usually denoted by $\mathrm{Y}_{\mathrm{i}, \mathrm{t}}$ that can take the values 0 (no-crisis) and 1 (crisis). In other words, the dependent variable is modeled as a binary response based on the crisis definition and takes the value 0 or 1 . On the right side of the model there are selected indicators as the independent variables.

Even though the EWS models are used for different types of economic crisis, here we will illustrate the case of a currency crisis. There are several critical aspects of the EWS model. These are as follows:

- Definition of a Crisis: The first property of an EWS model is to make a precise definition of the crisis (which is the dependent variable in the model). As we briefly explained in the introduction chapter, the currency crisis is theoretically defined as a large depreciation rate. However, empirical studies have used generally two approaches to define the currency crisis. While the first group follows more straightforward technique (depreciation based currency crisis definition) to define the crisis, the second approach (EMP Index based currency crisis definition) is more sophisticated and combines the effect of more than one economic variable into the definition. 
Scholars such as Frankel and Rose (1996), Larrain and Esquivel (1998), Milesi et al. (1998), Reinhart and Rogoff $(2009)^{7}$ define the currency crisis based on large currency depreciation or devaluation. As those scholars identify different critical levels to accept the presence of crisis and define the crisis accordingly, today, in the depreciation based currency crisis definition literature, there is not one level of depreciation as can be accepted as a currency crisis.

The second group, on the other hand, defines the crisis by constructing an Exchange Market Pressure index. According to this, instead of defining the currency only according to depreciation rate, scholars prefer to create an index with various economic variables ${ }^{8}$ and their weights. After defining the EMP index, an optimal cutoff level is chosen which consists of the arbitrarily determined $\delta$ (usually between 1 and 3) times standard deviation plus mean of the EMP index.

(Currency Crisis) $Y_{t}=\left\{\begin{array}{lc}1, \text { if EMP }>\delta \sigma_{\mathrm{EMP}}+\mu_{\mathrm{EMP}} \\ 0, & \text { otherwise }\end{array}\right.$

where $\sigma$ is the standard deviation of the exchange market pressure index and $\mu$ is the mean of the index.

If EMP index exceeds the threshold value, then the presence of the crisis is accepted for that period. In this sense, determination of an optimal cut-off value is crucial since this value discriminates crisis period from calm periods.

As for depreciation based definitions, in the literature of EMP index based definitions there is not a consensus on the crisis definition. Different scholars

\footnotetext{
${ }^{7}$ See Appendix A2 for the full currency crisis definitions of the scholars.

${ }^{8}$ How EMP index is calculated is explained in detail in Chapter 4.
} 
construct the EMP index with different variables or use different thresholds to accept the presence of the crisis.

- Explanatory Variables: The second property of EWS Model constructing is the selection of explanatory variables. It is important to identify which indicators provide useful information about a potential future crisis. Independent from the country coverage, time span and methodology, in the literature, some indicators have been proved more informative and significant in the prediction of crisis periods. It is possible to categorize some of the variables into groups such as current account indicators, capital account indicators, real sector indicators, and financial indicators (Kaminsky, 1998).

- Threshold Choices: Determination of an optimal threshold (cut-off) value is crucial since this value discriminates crisis period from tranquil periods. If the cut-off value is smaller than the predicted probability of a crisis, then the model signals of a forthcoming crisis. The smaller threshold value means more signals are sent (Type 1 error decreases). However it also means that the number of wrong signals increases (Type 2 error increases). On the other hand, higher cut-off level decreases the number of wrong signals but increases the number of missing crisis signals (Candelon et al., 2013). Thus, using the most appropriate threshold level for a specific Early Warning System model is crucial for the success rate of the model.

- Estimation Method: The construction of an EWS model requires an application of a methodology in order to estimate which indicators give a sufficient prediction power for dependent variable which is the probability of a crisis. The prediction gives different outcomes depending on econometric model that is used to estimate the model. Therefore, it is important to decide a suitable econometric 
method (Parametric or Non-Parametric Approaches) which works best with the chosen country set and data. 


\section{CHAPTER 3}

\section{LITERATURE REVIEW}

The attempts towards explaining currency crisis first arose in the 1970's when various Latin American countries (Mexico in 1976, Argentina, Brazil, Peru and again Mexico in 1980's) faced with currency crises and their costly damages. Following this initial period, with the increasing frequency of currency crises (the Exchange Rate Mechanism crisis in 1992, Tequila crisis in 1994, Asian crisis in 1997, Russian crisis in 1998, Argentine crisis in 1999 and 2002), the literature continued to grow considerably.

Those experiences have shown that although there are some common characteristics of the currency crises, not all crises are completely the same. Therefore, academics and economists continuously developed new models to explain those different currency crises. Today, the models which draw attention to different properties of currency crises can be grouped in three categories as first, second and third generation models.

The first generation models, which are developed after the currency crises in 1973 and 1982 in Mexico and other Latin American countries, are initially conceived by Krugman (1979) and improved by Flood et al. (1984). These models basically put

emphasis on the structural economic problems. According to these models, the 
structural incompatibility of macroeconomic policies (expansionary monetary policy and high budget deficits) and maintenance of the fixed exchange rate regime are seen as the main reasons of the currency crises. These models take attention to fiscal deficits depend on the large scale of monetary financing that causes reserve erosion and eventually an exchange rate peg. Therefore, they suggest that policymakers are able to implement consistent policies with the maintenance of a peg in order to prevent the currency crisis. Although the first generation models are developed in various scopes, they are criticized as they do not sufficiently explain the contagion effects of the crisis and the emergence of the balance of payment crisis in countries with strong economic fundamentals (Glick, 2011).

The second generation models are developed in order to explain speculative attacks on various national currencies such as Europe and Mexico in the early 1990's. According to these models, even if there is not a macroeconomic weakness or sustainable currency peg, a crisis can still occur. However, these second generation models failed to explain the speculative pressure and eventual turbulence periods. For this reason, third generation models which bring up the cross country contagion topic (Candelon et al. 2008) are developed. According to these models, a country's currency can be affected by a crisis that arises another country unrelated to economic fundamentals (Masson, 1998).

The empirical literature on Early Warning Systems of currency crisis has grown considerably especially after numerous currency crises in 1990's. Today, existing literature has a wide range of studies that tests various indicators, methodologies and investigates different countries and time periods and searches for the best econometric methods 9 .

\footnotetext{
${ }^{9}$ The lists of prominent studies are shown in Appendix A2 in detail.
} 
Girton and Roper (1977) make the first attempt to define currency crisis. To be able to define what the currency crisis is they use an Exchange Market Pressure index. They construct an index by combining international reserve losses and exchange rate depreciation. Following this study, the Exchange Market Pressure index is highly accepted by the academics and becomes a prominent tool to define a currency crisis. Eichengreen et al. (1994), Kaminsky et al. (1998), Kruger et al. (1998), Goldstein et al. (2000), Bussiere and Fratzscher (2002), Paltonen (2006) and Comelli (2014) are some of the scholars who use different versions of this index in their studies.

On the other hand, another group of scholars define the currency crisis by following totally different method. According to this, scholars such as Frankel and Rose (1996), Milesi et al. (1998) and Reinhart and Rogoff (2009) define currency crisis based on depreciation rate of currency rather than constructing an Exchange Market Pressure index.

In our thesis, we investigate the effects of crisis definitions and the threshold choices on prediction powers of the EWS models. As it is briefly stated in Chapter 2, in the literature, currency crises are defined in multiple ways which add up to vast currency crisis literature. However, as it can be seen above paragraphs, it is possible to group those definitions under two main groups; definitions that are based on depreciation rate and definitions that use Exchange Market Pressure (EMP) index. For this reason, in an attempt to reveal the definition differences more explicitly, we divided the related literature into two separate sections with respect to definition description: depreciation based definitions and Exchange Market Pressure index based definitions. 


\subsection{Depreciation Rate Based Definitions}

Frankel and Rose (1996) conduct a study in order to arrive a comprehensive statistical characterization of currency crisis and to find an answer whether the currency crisis can be predicted ex ante with standard economic indicators in developing countries. For this aim, they define a currency crisis as at least 25 percent nominal depreciation of currency for the current year and 10 percent more than the previous year's depreciation rate. In order to avoid counting the same crisis twice, they include crises that are at least 3 years apart. They consider more than 100 developing countries for the period of 1971-1992. They find that currency crashes occur when foreign direct investment inflows dry up, reserves are low, domestic credit growth is high, northern interest rates are rising, and the real exchange rate shows overvaluation. They observe that current account and government budget do not have significant effects on a currency crash.

Milesi-Ferretti and Razin (1998) extend the work done by Frankel and Rose (1996). In this study, they investigate the factors to predict the currency crisis and the impact of currency crisis on economic performance. For this purpose, they use four different currency crisis definitions in their study. The first definition is the same with Frankel and Rose (1996). They state that this definition captures large exchange rate fluctuations associated with high inflation episodes. Their second currency defines the crisis as in addition to 25 percent depreciation for the current year, depreciation rate should at least double with respect to the previous year and a rate of depreciation of the previous year should be below 40 percent. According to the third definition, for crisis to be present there should be at least 15 percent of depreciation, which should be at least 10 percent more than previous years' and the rate of depreciation of previous year should be less than 10 percent. The fourth definition 
defines the crisis the same with the third one but adds that the exchange rate should be pegged the year before the crisis. Milesi-Ferretti and Razin (1998) consider 105 countries (48 African countries, 26 Asian countries, 6 Latin American and Caribbean countries and 5 European countries) over the period between 1970 and 1996 and they use probit model. They find that low reserves, appreciated real exchange rate, high interest rate when the external conditions are unfavorable and low growth in industrial countries cause currency crisis.

Reinhart and Rogoff (2009) offer a detailed quantitative overview of the history of financial crisis dating from the mid-fourteenth century default of Edward III. In this comprehensive study, they are interested in both dating and duration of the currency crisis. The scholars define the currency crisis by following Frankel and Rose (1996) who focus on the rate of depreciation. According to that, they define the period as a crisis period if an annual depreciation of national currency versus US dollar (or the relevant anchor currency) is $15 \%$ or more. For their study, Reinhart and Rogoff (2009) cover the period between the years of 1800-2008 for 69 countries from Africa, Asia, Europe, Latin America, North America, and Oceania. They conclude that, the largest crashes are similar in timing and orders of magnitudes as the inflation profile.

\subsection{Exchange Market Pressure Index Based Definitions}

In an early study, Girton and Roper (1977) combine the changes in exchange rates and foreign exchange reserves and build the very first Exchange Market Pressure index. Following this study, EMP index becomes a preferred index that is used in EWS models by academics, policymakers and economists. 
Eichengreen et al. (1996) take the EMP model of Girton and Roper (1977) and utilize it in their work. In their study, they aim to analyze the contagious nature of currency crises. With this aim, they construct an Exchange Market Pressure index which is based on change in exchange rate, change in reserves and change in interest rate. They accept the presence of a currency crisis if this index exceeds the mean by 1.5 standard deviations. Scholars consider 20 industrialized economies for the years between 1959 and 1993. By using probit model they find that contagion appears to spread more easily to countries which are tied by international trade linkages compared to countries in similar macroeconomic circumstances.

One of the most important studies in the literature is done Kaminsky et al. (1998). In their study, they construct EMP index with weighted average of monthly percentage changes in the exchange rate (units of domestic currency per US dollar or per deutsche mark, depending on which is relevant) and the negative of monthly percentage changes in gross international reserves (in dollars). Periods where index is above its mean more than three standard deviations are defined as crisis. They use 15 developing and 5 developed countries between the years of 1970-1995. With this work, Kaminsky et al. (1998) bring a new technique for Early Warning Systems, which is called the signal approach. According to this non-parametric method, the indicators are identified by their non-normal behavior. Furthermore, with this study, the term a false signal or noise has introduced to literature. If an indicator sends a signal and there is a crisis then this is a good signal but if there is no crisis after the signal, then it is called a false signal or noise. They find that international reserves, the real exchange rate, domestic credit, credit to public sector and domestic inflation are the particularly useful indicators in anticipating the currency crisis. 
In their 1998 study, Kruger et al. aim to investigate if the macroeconomic variables, measure of lending booms, real exchange rate misalignment and the ratio of M2 to international reserves that are seen as causes of currency crises are the only variables that can be consistently related with the currency crises. For this aim, they too use EMP index in order to define currency crises. They define EMP index as a weighted average of percentage changes in the nominal exchange rate and negative of percentage changes in international reserves. If the index is 1.5 standard deviations above the mean, they accept the presence of the crisis. In their study they make a sensitivity analysis by changing the standard deviation to 1 . They note that this change increase the number of crisis in the sample from 23 to 39 and also the number of significant variables. They use probit model with 50\% threshold for 19 developing countries in order to examine the determinants of currency crises in developing countries. They conclude that lending booms, real exchange rate misalignment and reserve inadequacy increase the probability of a speculative attack on a currency.

Goldstein et al. (2000) analyze early warning indicators of banking and currency crisis. In this study, they define currency crisis as a weighted average of changes in the exchange rate and in foreign exchange reserves. They accept the presence of currency crisis if this index is more than 3 standard deviations from its mean. Their country set is comprised of 25 emerging countries for the time period of 1970-1995. By using a signal approach, they find the same indicators significant with Kaminsky et al. (1998). However, they include that banking crisis is also important in the context of predicting currency crisis.

Bussiere and Fratzscher (2002) set a broad set of economic and financial indicators in their study to test the role of indicators and they develop a methodology 
for the correction of the post crisis bias. By developing a multinomial logit regression model they distinguish tranquil, crisis and post-crisis periods. They define currency crisis based on EMP, which is weighted average of the change of the real effective exchange rate, the change in the interest rate and the change in foreign exchange reserves. They accept the presence of the crisis if index is above the mean by 2 standard deviations. They invetigate 20 countries between the time period 1993-2001. They obtain that multinomial logit regression has more success ratio than logistic model in terms of correctly predicting the currency crises. After Bussiere and Fratzscher (2002), in the Early Warning System literature, multinomial logit model is started to be preferred instead of binomial logit model.

Paltonen (2006) compares artificial neural network (ANN) model with probit model. They define the currency crisis based on EMP index. Paltonen (2006) constructs the index with the percentage change of the price of US dollar on a country's currency and percentage change in the level of the country's foreign reserves and accepts the presence of the crisis if this index is above its mean by 2 standard deviations. By investigating a country set that includes 24 countries between the periods 1980-2001 he finds that ANN model outperforms probit model; but eventually, both models show poor results in the prediction of the currency crisis.

Comelli (2013) compares parametric and non-parametric EWS prediction in sample and out of sample currency crisis in emerging market economies between the years of 1995-2011. He defines the currency crisis using EMP index which is a weighted average of one-month change in the exchange rate and foreign exchange reserves and accepts the presence of the crisis if the index is more than three standard deviations above the mean. He uses a fixed effects logit model in order to predict the 
currency crises. As a result, the scholar finds that parametric EWS achieves superior out of sample results compared to non-parametric EWS.

\subsection{Currency Crisis Prediction Success in the Literature}

We would like to review the success rates of the currency crisis prediction in the literature. Here we will focus on the threshold values used and prediction results.

In their study, Frankel and Rose (1996) who define currency crisis based on depreciation rate, take 50 percent probability threshold level. In their model, the ratio of correctly predicted currency crisis episodes is found as $46 \%$. However, the model shows success in predicting non-crisis periods with $92 \%$ success rate. The overall predictive power ${ }^{10}$ of the model is $91 \%$.

Milesi et al. (1998) extend the work done by Frankel and Rose (1996) and use four different currency crisis definitions in their study. They consider a 50 percent probability threshold for all definitions. According to this, the prediction power in the first model yields $92 \%$, while the second model yields $94 \%$ prediction power, third model yields $93 \%$ prediction power and the fourth model yields $93 \%$ prediction power.

In their pioneering study, by using a signal approach to estimate a EWS model they constructed, Kaminsky et al. (1998) try to identify variables that have the best track record in anticipating the currency crisis. They find that each indicator correctly called at least $\% 50$ (the ratio of the correctly predicted currency crisis episodes) of the currency crisis with an average of $70 \%$ (prediction power) success rate.

\footnotetext{
${ }^{10}$ Prediction power is calculated as follows: Total Number of Correctly Predicted Currency Crisis and non-Currency Crisis Episodes/Total Number of Currency and non-Currency Crisis Episodes.
} 
Bussiere and Fratzscher (2002) make a pioneering study by using multinomial logit regression to construct an Early Warning System. They also compare the success rates of logit model with multinomial logit regression in their study. They use a probability threshold of $20 \%$ to identify crisis signals. According to this, multinomial logit regression estimates the crises periods with $73.7 \%$ success, however this ratio falls to 66.7 for logistic regression. Likewise, the ratio of false alarms is $44.1 \%$ and $50 \%$ for multinomial logit regression and simple logit regression respectively.

In his study, Paltonen (2006) compares artificial neural network (ANN) model with probit model by taking four different probability thresholds $(10 \%, 15 \%$, $25 \%$, and $50 \%$ ) into account. The scholar finds that the impact of threshold value is less relevant in ANN models. Moreover, the currency crisis signals are more accurate in ANN model compared to probit model. He also adds that if a lower threshold value is identified, the model's ability to find tranquil periods decreases. In other words, the probit model tends to give more false signals compared to the ANN model. He concludes that both ANN and probit models do well in in-sample forecast while the prediction power decreases when it comes to out-of-sample forecast.

Comelli (2013) compares parametric and non-parametric EWS prediction in sample and out of sample currency crisis. He uses a fixed effects logit model with $50 \%$ probability threshold. The success rate of correctly predicted currency crisis of parametric model varies between 54\%-57\%, and non-crisis between $66 \%-70 \%$. However, the success rate of non-parametric model is $46 \%-60 \%$ for correctly called currency crisis episodes and $73 \%-81 \%$ for non-crisis episodes. He also concludes that the parametric EWS is more reliable in correctly predicting out-of-sample crisis episodes than the non-parametric EWS. The parametric EWS tends to have lower 
probabilities than the non-parametric EWS of missing crisis episodes when the EWS fails to issue an alarm.

In the next chapter, we introduce the data set we use for our analysis and the methodology to estimate and forecast our EWS models. In addition to those, we give the details of our currency crisis definitions and explanatory variables. 


\section{CHAPTER 4}

\section{DATA AND METHODOLOGY}

This thesis estimates an Early Warning System model where the probability of a currency crisis is estimated using economic variables as explanatory factor. The estimation methodology is logit model. This model is utilized to evaluate the prediction power under different specifications of the crisis variable and different threshold levels beyond which the prediction probability predicts a crisis. This chapter explains the data and methodology of this study.

\subsection{Data, Explanatory Variables, Time Period and Sample Countries}

In this study, the country set is the same with Reinhart and Rogoff (2009) which consists of 69 countries ${ }^{11}$ from six different regions. The country set is given in Table 4.1.

Table 4.1: Country Set

\begin{tabular}{c|l}
\hline Region & \multicolumn{1}{c}{ Countries } \\
\hline \multirow{3}{*}{ Africa } & $\begin{array}{l}\text { Algeria, Angola, Central African Republic, Cote D'Ivoire, Egypt, } \\
\text { Ghana, Kenya, Mauritius, Morocco, Nigeria, South Africa, Tunisia, } \\
\text { Zambia, Zimbabwe }\end{array}$ \\
\hline
\end{tabular}

${ }^{11}$ Except from Taiwan because of the data availability. 


\begin{tabular}{c|l}
\hline \multirow{2}{*}{ Asia } & $\begin{array}{l}\text { China, India, Indonesia, Japan, Korea, Malaysia, Myanmar, Philippines, } \\
\text { Singapore, Sri Lanka, Thailand }\end{array}$ \\
\hline \multirow{3}{*}{ Europe } & $\begin{array}{l}\text { Austria, Belgium, Denmark, Finland, France, Germany, Greece, } \\
\text { Iceland, Ireland, Italy, Netherlands, Norway, Poland, Portugal, } \\
\text { Romania, Russia, Spain, Sweden, Switzerland, Turkey, United } \\
\text { Kingdom }\end{array}$ \\
\hline Latin America & $\begin{array}{l}\text { Argentina, Bolivia, Brazil, Chile, Colombia, Costa Rica, Dominican } \\
\text { Republic, Ecuador, El Salvador, Guatemala, Honduras, Mexico, } \\
\text { Nicaragua, Panama, Paraguay, Peru, Uruguay, Venezuela }\end{array}$ \\
\hline North America & Canada, United States \\
\hline Oceania & Australia, New Zealand \\
\hline
\end{tabular}

The time period is set as 1970-2010 with annual observations. The explanatory variables are chosen by following the currency crisis literature. In total, 35 explanatory variables are chosen and 11 of them left for the final regression ${ }^{12}$. These indicators are classified in 8 groups as Capital Account Variables, Debt Profile Variables, Current Account Variables, International Variables, Financial Liberalization Variables, Other Financial Variables, Real Sector Variables, and Institutional/Structural Factors by following Kaminsky et al. (1998). The data are drawn from World Bank and IMF-IFS database and the empirical analysis is performed by using the software package Stata 11. The list of the explanatory variables is given in Table 4.2.

Table 4.2: Explanatory Variable Categories and the List of Variables

\begin{tabular}{c|c}
\hline \multicolumn{1}{c|}{ Variable Category } & \multicolumn{1}{c}{ Variables } \\
\hline Capital Account & $\begin{array}{l}\text { Net Foreign Direct Investment, The Ratio of Foreign } \\
\text { Direct Investment to GDP, Portfolio Equity Net Inflows }\end{array}$ \\
\hline &
\end{tabular}

12 Detailed explanation of the variable selection process is given in Chapter 5. Definitions of explanatory variables are given in Appendix A1. 
Short-term Debt (\% of Total Reserves), Public and publicly guaranteed debt service ( $\%$ of GNI), Multilateral Debt Service (\% of Public and Publicly Guaranteed Debt Service), Interest Payment on Total External Debt (\% of GNI), Total External Debt Stocks (\% of GNI), Domestic credit to private sector by banks (\% of GDP), Domestic Credit to Private Sector (\% of GDP), Total reserves ( $\%$ of total external debt), The Ratio of External Debt to GDP, Short-term debt (\%total external debt), Private non-guaranteed external debt stocks, Public and publicly guaranteed external debt stocks

\begin{tabular}{l|l} 
Current Account & $\begin{array}{l}\text { Real Effective Exchange Rate, Current account balance } \\
\text { (\%of GDP), Export growth (\% annual growth), Import } \\
\text { Growth (\% annual growth) }\end{array}$ \\
\hline International Variables & Use of IMF credit, Foreign Exchange Reserves \\
\hline Financial Liberalization & $\begin{array}{l}\text { Risk Premium on lending, Deposit interest rates, real } \\
\text { interest rate }\end{array}$ \\
\hline Other Financial Variables & The Ratio of M2 to GDP, M2 (\% of GDP) \\
\hline Real Sector & $\begin{array}{l}\text { Inflation Rate, GDP per Capita Growth, Unemployment } \\
\text { Rate, Gross Savings (\% of GDP) }\end{array}$ \\
\hline Institutional/Structural Factors & Degree of Openness for Trade \\
\hline
\end{tabular}

\subsection{Dependent Variables}

In this study, the currency crisis indicator is modeled as a binary response model in which predictions are interpreted as the probability of a crisis. According to the model, there is a crisis variable, usually denoted by $\mathrm{Y}_{i, t}$ that can take the values 0 (non-crisis) and 1 (crisis), i.e.; $\left(\operatorname{Pr}\left(\mathrm{Y}_{i, t}=1\right)\right.$ means the probability of country $i$ to experience a currency crisis at time t. The parametric logit estimation gives an opportunity to observe whether the explanatory variables that included in the model is significant explanatory power and have a predictive power for the probability of a possible future crisis. 
As mentioned in the previous chapters, one of the crucial steps for constructing an Early Warning System is to give an explicit definition of the crisis since the EWS must begin with a definition of crisis (Kindman, 2010).

It is possible to classify the crisis definitions in two groups:

- Exchange Market Pressure Index Based Currency Crisis Definitions

- Depreciation Based Currency Crisis Definitions

While the Depreciation Based Currency Crisis definitions recognizes a currency crisis based on changes in the depreciation rate, Exchange Market Pressure index based definitions usually comprised of combinations of different variables.

In this study, in order to investigate how different currency crisis definitions and probability thresholds change the prediction of the upcoming crisis, two prominent studies from the literature are chosen. According to this, while for the depreciation based currency crisis definition Reinhart and Ragoff's study (2009) is chosen, for the Exchange Market Pressure index based currency crisis definition, the definition of Eichengreen (1996) is used. These models differ in their definitions while other requisite components (in order to build an EWS) are kept as the same. Time period for all Early Warning System models covers 1970 to 2010 and the final data set is comprised of 11 explanatory variables. The econometric method is selected as logistic model on panel data set.

We rely on Eichengreen et al. (1996) and Reinhart (2009) and construct our currency crisis indicator. The definitions can be given as follows: 


\subsubsection{Depreciation Rate Based Currency Crisis Definition (Reinhart and Rogoff,}

2009):

Reinhart and Rogoff (2009) define currency crisis based on depreciation rate of the local currency against a relevant anchor currency instead of designing an exchange market pressure index. They consider a country is exposed to a currency crisis if an annual depreciation of national currency versus US Dollar (or relevant anchor currency) is $15 \%$ or more (Reinhart and Rogoff, 2009).

According to Reinhart and Rogoff (2009) currency crisis definition, binary variable takes the value 1 if the annual depreciation rate of a country's national currency versus US Dollar is $15 \%$ or more, and 0 otherwise.

\subsubsection{Exchange Market Pressure Index Based Currency Crisis Definition} (Eichengreen et al., 1996):

Eichengreen, Rose, and Wyplosz construct an Exchange Market Pressure Index which is the weighted average of the exchange rates changes $(\% \Delta \mathrm{e})$, international reserves changes $(\% \Delta r)$ and interest rate changes $(\% \Delta \mathrm{i})$. In this case Exchange Market Pressure Index can be shown as:

$E M P_{i, t}=\left[\left(\alpha \% \Delta e_{i, t}\right)+\left(\beta \Delta\left(i_{i, t}-i_{t}^{*}\right)\right)-\left(\gamma\left(\% \Delta r_{i, t}-\% \Delta r_{t}^{*}\right)\right)\right]$

where $e_{i, t}$ is the exchange rate of domestic currency relative to US Dollar at time $t$, $\Delta\left(\mathrm{i}_{\mathrm{i}, \mathrm{t}}-\mathrm{i}_{\mathrm{t}}{ }_{\mathrm{t}}\right)$ is the variation in the spread between domestic interest rates and US interest rate and $\left(\% \Delta \mathrm{r}_{\mathrm{i}, \mathrm{t}} \% \Delta \mathrm{r}_{\mathrm{t}}{ }^{\mathrm{t}}\right)$ is the percentage change in spread of international reserves ${ }^{13}$ that is abroad and at home. The currency crisis can be defined as follows:

${ }^{13} \mathrm{r}$ is the ratio of reserves to narrow money (M1) 


$$
\begin{aligned}
\operatorname{Crisis}_{i, t}\left(Y_{i, t}\right) & =1 \text { if } \operatorname{EMP}_{i, t}>1.5 \sigma_{E M P}+\mu_{E M P} \\
& =0 \text { otherwise }
\end{aligned}
$$

where $\sigma_{\mathrm{EMP}}$ and $\mu_{\mathrm{EMP}}$ is the standard deviation and mean of EMP respectively.

According to Eichengreen et al. (1996) currency crisis definition, binary variable (currency crisis) takes the value 1 if EMP exceeds its mean by 1.5 standard deviation and stated as crisis. Otherwise, binary variable takes the value 0 , meaning that there is no currency crisis and the country is in non-crisis period.

In the EMP of Eichengreen et al. (1996), there are three different indicators which have different volatilities. So it is important to aggregate these indicators by preventing the most volatile variable affect the whole index. Therefore, scholars suggest standardizing these three indicators by replacing each of the weights with the country specific standard deviation of the relative series in order to equalize the conditional volatilities of the components. This technique is called "precision weight".

\subsection{Methodology}

Even if the estimation techniques for anticipating the currency crisis under Early Warning Systems are vast, it is possible to categorize them under two groups as Parametric and Non-Parametric Approaches.

In the non-parametric approaches, signals analysis is used for the first time by Kaminsky et al. (1998). This approach is based on monitoring and identifying the selected variables. Deviation from individual variable's normal level to a determined threshold value adds up to a signal about an upcoming crisis. Conversely, in the 
parametric approach limited dependent variable (logit/probit) is used which is utilized by Frankel and Rose (1996) and Eichengreen et al. (1996).

It is important to note that the signal approach does not allow to test the statistical significance level of the variables. In this regard, it is suggested that this shortcoming can be alleviated by using parametric approach (Percic et al., 2013). Besides, parametric approach considers all explanatory variables together and reflects the marginal contribution of each indicator (Catillo, 2006). Moreover, Comelli (2013) explains that parametric approaches give superior results compared to non-parametric approaches. Additionally, in his 2014 study, he concludes that logit and probit Early Warning Systems are broadly similar. The logit Early Warning Systems classify between $42 \%-66 \%$ of the observations correctly whereas probit early warning systems 41\%-64\% (Comelli, 2014).

Therefore, in this study parametric approach is taken into consideration and logistic regression is used as an estimation technique. Moreover, since the subject of the study is currency crisis, which is a binary variable from a qualitative point of view (depending on the existence of a currency crisis or not), binary choice models has been considered in their analysis. In binary choice models, if the considered event occurs, the dependent variable takes the value 1 and 0 otherwise. In this study $P_{i, t}$ is the probability of the the currency crisis and $\left(1-P_{i, t}\right)$ is otherwise. $y_{i, t}=1$ implies that country $i$ has experienced a currency crisis in time $t$ and $y_{i, t}=0$ otherwise. $E\left(y_{i, t}\right)$ is the expected value of the crisis variables which is equal to the probability of crisis occurrence and is modeled by:

$$
E\left(y_{i, t}\right)=1 . p_{i, t}+0 .\left(1-p_{i, t}\right)=p_{i, t}
$$

which is generally modeled as a function of some explanatory variables: 


$$
P_{i, t}=\operatorname{Pr}\left(Y_{i, t}=1\right)=E\left(Y_{i, t} \mid X_{i, t}\right)=f\left(X_{i, t}^{\prime} \beta\right)
$$

As a binary choice model, logistic regression is used relying on the advantages such as; allowing properties of a linear regression model to be exploited, can take the values between $-\infty$ and $+\infty$ whereas the probability remains constrained between $0-1$ and directly related to odds ratio (the changes in the model can totally be reflected to the ratio).

Logistic regression measures the relationship between a dependent variable and one or more independent variables by using probability scores as the predicted values of the dependent variable.

Logistic function is used for the explanation of the logistic regression which can be given as follows:

$$
P_{i}=e\left(Y=1 \mid X_{i}\right)=\frac{1}{1+e^{-x t \beta_{j}}}
$$

where $\mathrm{j}$ is the linear function of the explanatory variable $\mathrm{x}$ and the logistic function is:

$$
P_{i}=\frac{1}{1+e^{-z_{i}}}=\frac{e^{z}}{1+e^{z}} \text { where } \mathrm{z}_{\mathrm{i}}=\mathrm{X}_{\mathrm{i}, \beta_{\mathrm{j}}}
$$

which is interpreted as the probability of occurrence of the event. Additionally, $\beta_{0}$ is the intercept from the linear equation, $\beta_{1} x$ is the regression coefficient multiplied by the predictor and $\mathrm{e}$ is the exponential term.

The graph of the logistic function is given in figure 4.1. In the graph, $\beta_{0}+\beta_{1}$ lies on the horizontal axis whereas $\mathrm{F}(\mathrm{x})$ on the vertical axis. 


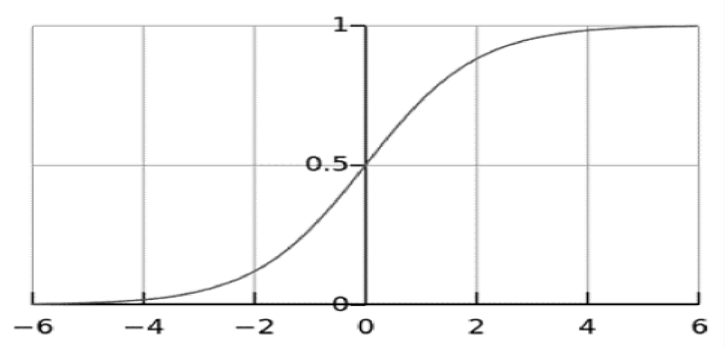

Figure 3.1: Logistic Distribution Function

In this function, F represents the probability of occurrence of the event which is explained by a set of variables. Even if the value of the linear regression expression can vary from negative to positive infinity, after transformation the resulting expression for $\mathrm{F}(\mathrm{x})$ ranges from 0 - 1 . In other words, since the distribution is exponential, the dependent variable cannot exceed 1 and fall under 0 regardless of the value of the explanatory variables.

In this chapter of the study, the data and methodology of this study are given. In the next chapter, using the same set of explanatory variables, econometric method (logistic regression), country set and time period (1970-2010) for both crisis definitions, we aim to find the most significant explanatory variable set that explain the probability of a currency crisis which is relevant for both definition approaches of currency crisis. 


\section{CHAPTER 5}

\section{EMPIRICAL RESULTS OF CRISIS PROBABILITY ESTIMATION}

The first step in Early Warning System models is to estimate a model for probability of a crisis occurring. This probability is modelled as a binomial choice model where dependent variable takes the value of 1 when a crisis is said to occur and 0 when there is no crisis, according to a crisis indicator in an economy. The model explains the probability of a crisis as a function of explanatory variables which describe the economic, political and social condition of the country.

Our main hypothesis is that how you define a currency crisis has important repercussion for the success of the EWS model. In the literature there are two prominent approaches in defining the occurrence of a currency crisis. The first one is based on the rate of depreciation of the domestic currency. The second one is based on an indicator generally referred to as Exchange Market Pressure index.

Prior to assessing the predictive power of the EWS models used in currency crisis, the purpose in this chapter is to determine the most significant explanatory variables and the most relevant economic conditions that explain the probability of a 
currency crisis. Our aim is to find a broad set of explanatory variables that is relevant for both type of definition approaches of currency crisis.

Using the sample explained in the previous chapters which consists of annual data of 69 countries for the period 1970-2010, we examine whether information on variables on real sector, financial liberalization conditions, other financial sector information, current account, debt profile, capital account, and international economic conditions has explanatory power on the currency crisis. In the first stage of empirical analysis we have conducted logit estimations using combinations of various explanatory factors. In our initial estimations we see that 11 explanatory variables ${ }^{14}$ have some effect on either one or both of the dependent variables used as binomial crisis variable defined according to two alternative definitions.

After the first stage of the elimination of the explanatory variables, we would like to report results of models where the crisis definitions of Reinhart and Rogoff (2009) and Eichengreen et al. (1996) are used as dependent variables. In the first category we use variables for the real sector and economic conditions which are GDP per capita growth, net national savings and inflation rate. As a next step, in addition to these variables we added variables for financial sector and financial liberalization. These are deposit interest rate, the ratio of M2 to international reserves. As a measure of countries' competitiveness, real effective exchange rate; as measures of debt profile, public and publicly guaranteed external debt stocks, domestic credit provided by banking sector ( $\%$ of GDP) and total reserves ( $\%$ of total external debt) are included into estimations. Furthermore, as a measure of capital account; the ratio of FDI to GDP, portfolio equity net inflows (BoP, current US\$) are included into

\footnotetext{
${ }^{14}$ GDP per Capita Growth, Inflation Rate, Net National Savings (\% of GNI), the Ratio of M2 to International Reserves, Deposit Interest Rate, Real Effective Exchange Rate, Domestic Credit Provided by Banking Sector, Public and Publicly Guaranteed External Debt Stocks, Total Reserves (\% of Total External Debt), the Ratio of Foreign Direct Investment to GDP, Portfolio Equity Net Inflows
} 
models. In the final step, the explanatory variable set that constitutes only the significant variables for each EWS models are obtained.

In sections 5.1 and 5.2, the results of this empirical analysis are reported. While Section 5.1 presents the models where currency crisis is defined according to the rate of depreciation of nominal exchange rate like Reinhart and Rogoff (2009) definition, Section 5.2 summarizes empirical results of the models where EMP index is used as a crisis definition such as Eichengreen et al. (1996).

\subsection{Nominal Exchange Rate Depreciation-Based Crisis Definition}

Reinhart and Rogoff define currency crisis in their 2009 study as an annual nominal depreciation of a currency of at least $15 \%$. Table 5.1 below presents the empirical results of the logistic regressions for the model where we define the dependent variable of a currency crisis where nominal depreciation rate is above $15 \%$ in our sample.

The table reports results of regressions for Model 1 to Model 7, where each model is constructed by separately adding each group of explanatory variable into the estimation.

Table 5.1: Empirical Results of the Models that constructed with Reinhart and Rogoff (2009) Currency Crisis Definition

\begin{tabular}{|c|c|c|c|c|c|c|c|c|}
\hline & Model 1 & Model 2 & Model 3 & Model 4 & Model 5 & Model 6 & Model 7 & Final \\
\hline $\begin{array}{l}\text { GDP per Capita } \\
\text { Growth }\end{array}$ & $\begin{array}{c}-0.000380^{* * * *} \\
(-2.75)\end{array}$ & $\begin{array}{c}-0.000359^{* *} \\
(-2.55)\end{array}$ & $\begin{array}{c}-0.000371^{* *} \\
(-2.45)\end{array}$ & $\begin{array}{c}-0.000371^{* *} \\
(-2.43)\end{array}$ & $\begin{array}{c}-0.000348^{*} \\
(-1.75)\end{array}$ & $\begin{array}{c}-0.000354^{*} \\
(-1.78)\end{array}$ & $\begin{array}{c}-0.000394 * \\
(-1.71)\end{array}$ & $\begin{array}{c}-0.000272 * * \\
(-2.25)\end{array}$ \\
\hline $\begin{array}{l}\text { Net National } \\
\text { Savings }\end{array}$ & $\begin{array}{c}0.0000115 \\
(0.07)\end{array}$ & $\begin{array}{c}0.0000437 \\
(0.26)\end{array}$ & $\begin{array}{c}-0.000101 \\
(-0.56)\end{array}$ & $\begin{array}{c}-0.0000719 \\
(-0.39)\end{array}$ & $\begin{array}{c}-0.000390 \\
(-1.62)\end{array}$ & $\begin{array}{c}-0.000387 \\
(-1.60)\end{array}$ & $\begin{array}{c}-0.000373 \\
(-1.48)\end{array}$ & \\
\hline Inflation Rate & $\begin{array}{c}-0.0000237 \\
(-0.15)\end{array}$ & $\begin{array}{c}0.0000365 \\
(0.23)\end{array}$ & $\begin{array}{c}0.000131 \\
(0.77)\end{array}$ & $\begin{array}{c}0.000146 \\
(0.86)\end{array}$ & $\begin{array}{c}0.000345 \\
(1.50)\end{array}$ & $\begin{array}{c}0.000348 \\
(1.51)\end{array}$ & $\begin{array}{c}0.000433^{*} \\
(1.76)\end{array}$ & $\begin{array}{c}0.000123 \\
(0.90)\end{array}$ \\
\hline $\begin{array}{l}\text { The Ratio of M2 } \\
\text { to International } \\
\text { Reserves }\end{array}$ & & $\begin{array}{c}-0.00109 * * * \\
(-4.05)\end{array}$ & $\begin{array}{c}-0.00123^{* * *} \\
(-4.27)\end{array}$ & $\begin{array}{c}-0.00124^{* * *} \\
(-4.32)\end{array}$ & $\begin{array}{c}-0.00237 * * * \\
(-5.15)\end{array}$ & $\begin{array}{c}-0.00242 * * * \\
(-5.00)\end{array}$ & $\begin{array}{c}-0.00279 * * * \\
(-5.11)\end{array}$ & $\begin{array}{c}-0.000947^{* * *} \\
(-4.05)\end{array}$ \\
\hline Deposit Interest & & & -0.000423 & -0.000439 & -0.000512 & -0.000510 & -0.000490 & \\
\hline
\end{tabular}




\begin{tabular}{|c|c|c|c|c|c|c|c|c|}
\hline Rate & & & $(-1.47)$ & $(-1.52)$ & $(-1.34)$ & $(-1.34)$ & $(-1.24)$ & \\
\hline $\begin{array}{l}\text { Real Effective } \\
\text { Exchange Rate }\end{array}$ & & & & $\begin{array}{c}0.000726^{*} \\
(1.87)\end{array}$ & $\begin{array}{c}0.00117^{*} \\
(1.82)\end{array}$ & $\begin{array}{c}0.00117^{*} \\
(1.82)\end{array}$ & $\begin{array}{c}0.00121^{*} \\
(1.81)\end{array}$ & $\begin{array}{c}0.000127 \\
(0.50)\end{array}$ \\
\hline $\begin{array}{l}\text { Domestic Credit } \\
\text { Provided by } \\
\text { Banking Sector } \\
\text { (\% of GDP) }\end{array}$ & & & & & $\begin{array}{c}0.00110^{* * * *} \\
(2.66)\end{array}$ & $\begin{array}{c}0.00111^{* * *} \\
(2.67)\end{array}$ & $\begin{array}{c}0.00149^{* * * *} \\
(3.10)\end{array}$ & $\begin{array}{c}0.000251 \\
(1.39)\end{array}$ \\
\hline $\begin{array}{l}\text { Public and } \\
\text { Publicly } \\
\text { Guaranteed } \\
\text { External Debt } \\
\text { Stocks }\end{array}$ & & & & & $\begin{array}{c}-0.000147 \\
(-0.33)\end{array}$ & $\begin{array}{c}-0.000146 \\
(-0.33)\end{array}$ & $\begin{array}{c}-0.000217 \\
(-0.46)\end{array}$ & \\
\hline $\begin{array}{l}\text { Total Reserves } \\
\text { (\% of Total } \\
\text { External Debt) }\end{array}$ & & & & & $\begin{array}{c}-0.000481 \\
(-1.49)\end{array}$ & $\begin{array}{c}-0.000465 \\
(-1.43)\end{array}$ & $\begin{array}{c}-0.000480 \\
(-1.36)\end{array}$ & \\
\hline $\begin{array}{l}\text { The Ratio of } \\
\text { Foreign Direct } \\
\text { Investment to } \\
\text { GDP }\end{array}$ & & & & & & $\begin{array}{c}0.0000992 \\
(0.37)\end{array}$ & $\begin{array}{c}0.000116 \\
(0.40)\end{array}$ & \\
\hline $\begin{array}{l}\text { Portfolio Equity } \\
\text { Net Inflows }\end{array}$ & & & & & & & $\begin{array}{c}0.000217 \\
(0.38)\end{array}$ & \\
\hline$N$ & 1285 & 1285 & 987 & 987 & 567 & 567 & 520 & 1662 \\
\hline Log Likelihood & -293.80857 & -284.8354 & -241.67062 & -239.8232 & -145.17786 & -145.11027 & -131.68731 & -379.47408 \\
\hline LR chi2 & 7.71 & 25.66 & 30.83 & 34.52 & 51.32 & 51.45 & 52.60 & 25.09 \\
\hline Prob > chi2 & 0.0523 & 0.0000 & 0.0000 & 0.0000 & 0.0000 & 0.0000 & 0.0000 & 0.0001 \\
\hline
\end{tabular}

t statistics in parentheses

$* p<0.1, * * p<0.05, * * * p<0.01$

Estimates are fixed effect panel estimation results

Using a nonparametric bootstrap, Stata provides a heteroscedasticity robust covariance

According to the results, GDP per capita growth is a significant indicator of currency crisis. It is significant in all models and it keeps its significance in the final model too. Its significances change from $1 \%, 5 \%$ and $10 \%$ levels. As it is expected GDP per capita growth has a negative sign, meaning that increasing values of this variable decreases the possibility of a currency crisis.

Inflation rate yields insignificant results in all models except the Model 7. In Model 7, the inflation rate is significant at $10 \%$ level with positive sign. Therefore, an increase in inflation increases the probability of the currency crisis.

The ratio of $\mathrm{M} 2$ to international reserves is also a significant indicator of crisis. The final model that is constructed with the combination of significant explanatory variables from previous models too confirms the significance of this variable on explaining the currency crisis. In all regressions, it is significant at $1 \%$ level. The results show that there is a negative relationship between the ratio of M2 
to international reserves and occurrence of currency crisis. Therefore, the probability of currency crisis decreases with increasing values of the ratio of M2 to international reserves.

The variables domestic credit to banking sector and real effective exchange rate are significant crisis indicators when they are tested in Models 4, 5, 6, and 7. Positive signs of those variables show that with increasing value of domestic credit to banking sector and real effective exchange rate, the possibility of currency crisis increases. However, an interesting outcome is that when those variables are combined with GDP per capita growth and the ratio of M2 to international reserves in the final model, they do not show significant results anymore.

The variables net national savings, deposit interest rate, public and publicly guaranteed external debt stocks, total reserves ( $\%$ of total external debt), the ratio of foreign direct investment to GDP and portfolio equity net inflows are not significant at any significance levels in any of the models.

To sum up, regression results shows that among real sector variables, only GDP per capita growth is a significant indicator of currency crisis. The sign of the coefficient shows that the higher the GDP per capita growth rate the lower will be the probability of a currency crisis. Other factors that are found to be important in explaining the probability of currency crisis are inflation, the ratio of M2 to international reserves, real effective exchange rate, and domestic credit provided by banking sector (\% of GDP). An increase in inflation increases the probability of a currency crisis as expected. The monetary expansion compared to the international reserves seems to have a decreasing effect on the probability of a currency crisis. Furthermore, an increase in real effective exchange rate increases the probability of the crisis. Lastly, the results imply that an increase in the domestic credit provided in 
the banking sector (\% of GDP) increases the probability of the currency crisis. We constructed a final model by using only the significant variables from previous regressions. In this final regression, two variables which are GDP growth per capital and the ratio of M2 to international reserves are found significant.

\subsection{Exchange Market Pressure Index-based Crisis Definition}

In their work Eichengreen et al. (1996) computed an index called Exchange Market Pressure (EMP) by using the changes on the exchange rate, reserves and the interest rates and used as a crisis indicator ${ }^{15}$. The below table presents the empirical result of the logistic regression for a model that constructed with Eichengreen et al. (1996) currency crisis definition. As it is in the previous analysis, there are 7 models with different sets of explanatory variables. The final regression is conducted with the explanatory variables that are significant in other previous models.

Table 5.2: Empirical Results for the Models according to Eichengreen et al. (1996) Currency Crisis Definition

\begin{tabular}{|c|c|c|c|c|c|c|c|c|}
\hline & Model 1 & Model 2 & Model 3 & Model 4 & Model 5 & Model 6 & Model 7 & Final \\
\hline \multirow{2}{*}{$\begin{array}{l}\text { GDP per Capita } \\
\text { Growth }\end{array}$} & -0.000757 *** & $-0.000839 * * *$ & $-0.000669^{* *}$ & $-0.000645^{* *}$ & $-0.000731^{* * *}$ & $-0.000711^{*}$ & $-0.000968 * *$ & $-0.000711^{* * * *}$ \\
\hline & $(-3.05)$ & $(-3.29)$ & $(-2.25)$ & $(-2.16)$ & $(-1.98)$ & $(-1.89)$ & $(-2.33)$ & $(-2.58)$ \\
\hline Net National & -0.0000812 & -0.0000444 & 0.00000756 & 0.0000297 & 0.000154 & 0.000143 & 0.0000708 & \\
\hline Savings & $(-0.32)$ & $(-0.17)$ & $(0.02)$ & $(0.09)$ & $(0.40)$ & $(0.37)$ & $(0.18)$ & \\
\hline Inflation Rate & $\begin{array}{l}0.000454^{*} \\
(1.93)\end{array}$ & $\begin{array}{c}0.000570^{* * *} \\
(2.32)\end{array}$ & $\begin{array}{l}0.000517 * \\
(1.76)\end{array}$ & $\begin{array}{l}0.000513 * \\
(1.76)\end{array}$ & $\begin{array}{c}0.000454 \\
(1.31)\end{array}$ & $\begin{array}{c}0.000451 \\
(1.30)\end{array}$ & $\begin{array}{l}0.000677 * \\
(1.84)\end{array}$ & $\begin{array}{l}0.000442 * \\
(1.68)\end{array}$ \\
\hline $\begin{array}{l}\text { The Ratio of M2 } \\
\text { to International } \\
\text { Reserves }\end{array}$ & & $\begin{array}{c}-0.00104 * * * \\
(-2.88)\end{array}$ & $\begin{array}{c}-0.000794 * * \\
(-1.99)\end{array}$ & $\begin{array}{c}-0.000810^{* *} \\
(-2.00)\end{array}$ & $\begin{array}{c}-0.00138^{* *} \\
(-2.36)\end{array}$ & $\begin{array}{c}-0.00139 * * \\
(-2.37)\end{array}$ & $\begin{array}{c}-0.00169 * * * \\
(-2.70)\end{array}$ & $\begin{array}{c}-0.00156^{* * * *} \\
(-3.53)\end{array}$ \\
\hline $\begin{array}{l}\text { Deposit Interest } \\
\text { Rate }\end{array}$ & & & $\begin{array}{c}0.000152 \\
(0.30)\end{array}$ & $\begin{array}{c}0.000192 \\
(0.38)\end{array}$ & $\begin{array}{c}-0.0000569 \\
(-0.09)\end{array}$ & $\begin{array}{c}-0.0000195 \\
(-0.03)\end{array}$ & $\begin{array}{c}0.000106 \\
(0.16)\end{array}$ & \\
\hline $\begin{array}{l}\text { Real Effective } \\
\text { Exchange Rate }\end{array}$ & & & & $\begin{array}{c}0.000566 \\
(1.03)\end{array}$ & $\begin{array}{c}0.000581 \\
(0.87)\end{array}$ & $\begin{array}{c}0.000573 \\
(0.86)\end{array}$ & $\begin{array}{c}0.000585^{* * *} \\
(2.83)\end{array}$ & $\begin{array}{c}0.000810^{* * *} \\
(2.21)\end{array}$ \\
\hline $\begin{array}{l}\text { Domestic Credit } \\
\text { Provided by } \\
\text { Banking Sector }\end{array}$ & & & & & $\begin{array}{c}-0.000615 \\
(-1.22)\end{array}$ & $\begin{array}{c}-0.000625 \\
(-1.23)\end{array}$ & $\begin{array}{c}-0.000742 \\
(-1.43)\end{array}$ & \\
\hline $\begin{array}{l}\text { Public and } \\
\text { Publicly } \\
\text { Guaranteed } \\
\text { External Debt } \\
\text { Stocks }\end{array}$ & & & & & $\begin{array}{c}-0.000266 \\
(-0.35)\end{array}$ & $\begin{array}{c}-0.000226 \\
(-0.29)\end{array}$ & $\begin{array}{c}-0.000146 \\
(-0.18)\end{array}$ & \\
\hline
\end{tabular}




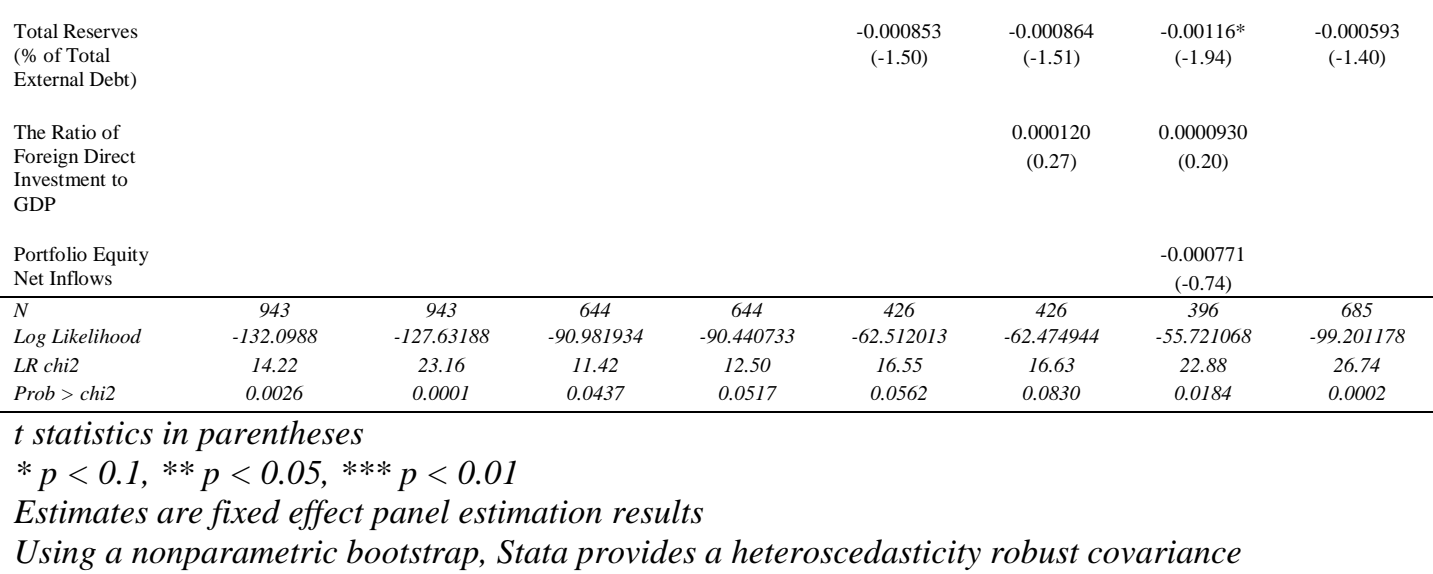

According to the estimation results, GDP per capita growth is an important indicator of a currency crisis when EMP index based currency definition is used. It is significant with a negative sign in all models. In other words, this variable keeps it is significance even though it is considered with different variable sets. It is significant at different level of confidence $(1 \%, 5 \%$ and $10 \%)$. GDP per capita growth has a negative impact on the probability of a currency crisis. As expected, if GDP per capita growth rate increases the probability of a currency crisis decreases as expected.

The inflation rate is significant in first sets of models, but loses significance when debt profile measures (domestic credit to banking sector, public and publicly guaranteed external debt shocks and total reserves) are included into the model. This variable has a positive impact on the occurrence of a currency crisis meaning that increasing values of inflation rate increases the possibility of currency crisis as expected.

According to the empirical results, the ratio of M2 to international reserves is another important variable for the logit regressions that are constructed with EMP index based currency definitions. It is significant at 5\% confidence level depending on the explanatory variables sets that it is used with. As M2 to international reserves increases probability of a crisis decreases. 
Real effective exchange rate yields significant results at 5\% significance level only in some models and is not robust to model specifications. As it is expected increase in real effective exchange rate increases the probability of a crisis.

The variable total reserves (\% of total external debt) reveals significant result in Model 7 with negative sign. Therefore, an increase on total reserves decreases the probability of crisis as expected. However, when total reserves (\% of total external debt) is regressed with GDP per capita growth, the ratio of M2 to international reserves, inflation rate and real effective exchange rate in the final model, it does not show significant results anymore.

Furthermore, the variables net national savings, domestic credit provided by banking sector, public and publicly guaranteed external debt stocks, the ratio of foreign direct investment to GDP and portfolio equity net inflows are not significant indicators of a currency crisis when currency crisis is defined according to Eichengreen et al. (1996) for an Early Warning System model.

As a final model we constructed a regression with only the significant variables. Out of these, the remaining significant variables are GDP per capita growth, the ratio of $\mathrm{M} 2$ to international reserves, inflation rate and real effective exchange rate are significant indicators of a currency crisis according to the model which is constructed with EMP index.

In this chapter of our thesis, we investigated 2 main crisis definition approaches and their impacts on the EWS models. The results of the estimations of the models that are constructed with these different approaches have shown that, different definition methods identify different sets of variables as crisis indicators. While GDP per capita, inflation, the ratio of M2 to international reserves, real effective exchange rate and domestic credit provided by banking sector are 
significant in at least one of the regressions for the depreciation-based currency crisis definition; GDP per capita, inflation rate, the ratio of M2 to international reserves, real effective exchange rate and total reserves are significant in at least one of the regressions for the EMP index based currency crisis definition. These findings are important in the EWS analysis as we incorporate those significant variables while forecasting the performances of the models that are constructed with different currency crisis definitions in the next chapter.

The next chapter examines the prediction power of EWS models by using alternative versions of crisis definitions. According to this in the next chapter, different depreciation rates are used to analyze the impacts of alternative versions of Reinhart and Ragoff's (2009) crisis definition on the prediction power of EWS models. To test the alternative versions of EMP index of Eichengreen et al. (1996), first, the construction of the index is changed by adding new variables into it. Second, the construction of the index is kept the same as suggested by Eichengreen et al. (1996) but different levels of standard deviations are used. When we predict a crisis, probability is continuous whereas the crisis definition is binomial. Hence, we need to choose a threshold level of probability beyond which the estimated probability predicts currency crisis. Therefore, a second criterion subject to which we will examine the prediction powers in the next chapter is these alternative threshold levels. 


\section{CHAPTER 6}

\section{SUCCESS OF EWS MODEL UNDER ALTERNATIVE CRISIS DEFINITIONS AND PROBABILITY THRESHOLD CHOICES}

As was explained in the previous chapters, there are mainly two groups of definitions of currency crisis events. While the first group looks at the rate of depreciation in the nominal exchange rate, the other group uses a measure called Exchange Market Pressure index that is constructed using several variables. Today, there is a variety of currency crisis definitions in the literature which can be broadly grouped under these two. By focusing two prominent crisis definition methods, Chapter 5 has shown how different definitions of a currency crisis result in the significances of different economic variables in EWS models.

The purpose of this chapter is to evaluate the prediction powers of the Early Warning Systems. Therefore, we primarily focus on the impact of different crisis definitions on prediction performance. Another critical issue for the performance of EWS models is the choice of probability thresholds as chosen threshold level is crucial while forecasting a crisis. Therefore, in this chapter we are going to look at the prediction powers of the EWS models under alternative variations of crisis definitions and probability threshold levels. 


\subsection{Alternative Crisis Definitions}

While Rienhart and Rogoff (2009) use depreciation based currency crisis definition, Eichengreen et al. (1996) use Exchange Market Pressure index to define the currency crisis. In the literature, today there are different versions of those methods. Following from the literature, the currency crisis definitions used can be categorized in three subgroups:

i. Depreciation Based Currency Crisis Definitions

ii. Exchange Market Pressure Index Based Currency Crisis Definitions with Varying Variables

iii. Exchange Market Pressure Index Based Currency Crisis Definitions with Varying Standard Deviation Multiplier

While Reinhart and Rogoff (2009) define the currency crisis as $15 \%$ or more annual depreciation versus US dollar (or the relevant anchor currency), Frankel and Rose (1996) take the previous year's depreciation rate into account as well. Therefore, they accept the presence of a currency crisis only if the nominal depreciation rate of currency is greater than 25 percent for the current year and greater than 10 percent of the previous year. Similar to Frankel and Rose (1996), Milesi et al. (1998) define the crisis as in addition to 25 percent depreciation for the current year, depreciation rate should at least double with respect to the previous year and a rate of depreciation the previous year should be below 40 percent.

The similar versions are valid for EMP measure as well. According to that, while Eichengreen et al. (1996) construct their EMP index with the changes on the exchange rate, the reserves and the interest rates ${ }^{16}$, Kaminsky et al. (1998) use

\footnotetext{
${ }^{16}$ Technical details of the EMP index are given in Chapter 4.
} 
average of monthly percentage changes in the exchange rate (units of domestic currency per US dollar or per deutsche mark, depending on which is relevant) and the negative of monthly percentage changes in gross international reserves (in dollars). On the other hand, Bussiere and Fratzscher (2002) use the change of the real effective exchange rate, the interest rate and the foreign exchange reserves to construct an EMP index to define a currency crisis.

In literature, another set of variations of EMP index are obtained by changing the multiplier of the standard deviation in order to change the definition of the currency crisis event.

Once EMP index is established, a cut-off value is used to determine in which conditions and time period this index points out a currency crisis. The cut-off value (threshold level) is calculated by summing up the mean of EMP index and standard deviation of the index. And if the index is higher than the mentioned sum, the presence of a currency crisis is accepted. For instance, Li et al. (2006) use the same explanatory variables with Eichengreen et al. (1996) in order to construct an EMP index for defining the currency crisis. However, they accept the presence of the crisis if the index exceeds the level of its means as much as 3 standard deviations. In other words according to Li et al. (2006) if the EMP index exceeds a threshold level which is 3 standard deviations above its mean, there is a currency crisis. Eichengreen et al. (1996) identify the threshold level as 1.5 standard deviations above the mean of the index $^{17}$.

The alternative currency crisis definitions that are selected for our analysis can be explained as follows: For the first 8 definitions, currency crisis is defined based on depreciation rate (versions of Reinhart and Rogoff (2009) method). The

${ }^{17}$ See Table 6.3 
definitions cover different depreciation rates based on the existing studies on the issue.

For the definitions 9 to 13 , currency crisis is defined using the Exchange Market Pressure index. For those definitions, prominent Exchange Market Pressure index based currency crisis definitions in the literature (different versions of Eichengreen et al. (1996)) are taken into consideration which in terms of variables that are used to construct the index.

The definitions 14 to 20 have the same variables with the Exchange Market Pressure index of Eichengreen et al. (1996) but differ in the multiplier of the standard deviations. According to this, the index is constructed with weighted average of exchange rate changes, reserve changes, and interest rate changes. Originally, Eichengreen et al. (1996) suggest that currency crisis occurs if the value of the index exceeds the mean more than 1.5 standard deviations of the index. However, from definitions 14 to model 20, different standard deviation multipliers are used.

The alternative crisis definitions are given in Table 6.1, Table 6.2 and Table 6.3 as follows:

Table 6.1: Depreciation Rate Based Currency Crisis Definitions

\begin{tabular}{|c|c|c|c|}
\hline & $\begin{array}{l}\text { Annual depreciation of } \\
\text { domestic currency versus US } \\
\text { dollar }\end{array}$ & Additional Conditions & $\begin{array}{l}\text { \# of Currency } \\
\text { Crisis }\end{array}$ \\
\hline Def 1 & $15 \%$ & & 187 \\
\hline Def 2 & $25 \%$ & & 116 \\
\hline Def 3 & $35 \%$ & & 82 \\
\hline Def 4 & $25 \%$ & $\begin{array}{l}\text { The rate of the previous year } \\
\text { depreciation is below } 40 \%\end{array}$ & 41 \\
\hline Def 5 & $15 \%$ & $\begin{array}{l}\text { annual depreciation with respect to } \\
\text { previous year is also more than } 10 \%\end{array}$ & 138 \\
\hline Def 6 & $25 \%$ & $\begin{array}{l}\text { annual depreciation with respect to } \\
\text { previous year is also more than } 10 \%\end{array}$ & 87 \\
\hline Def 7 & $35 \%$ & $\begin{array}{l}\text { annual depreciation with respect to } \\
\text { previous year is at least doubled }\end{array}$ & 66 \\
\hline Def 8 & $25 \%$ & $\begin{array}{l}\text { annual depreciation with respect to } \\
\text { previous year is also more than } 10 \%\end{array}$ & 42 \\
\hline
\end{tabular}


Table 6.2: Exchange Market Pressure Index Based Currency Crisis Definitions with Varying Variables

\begin{tabular}{rlcc} 
& \multicolumn{1}{c}{ Variables in EMP index } & $\begin{array}{c}\text { Multiplier of the } \\
\text { Standard Deviation }\end{array}$ & $\begin{array}{c}\text { \# of Currency } \\
\text { Crisis }\end{array}$ \\
\cline { 2 - 4 } Def 9 & $\begin{array}{l}\text { Weighted average of the nominal exchange rate and } \\
\text { international reserves }\end{array}$ & 106 \\
Def 10 & $\begin{array}{l}\text { Weighted average of the nominal exchange rate, } \\
\text { interest rate and foreign exchange reserves }\end{array}$ & 2 & 122 \\
$\begin{array}{l}\text { Defighted average of the real exchange rate growth, } \\
\text { interest rate growth and international reserves growth }\end{array}$ & 2 & 213 \\
Def 12 & $\begin{array}{l}\text { Weighted average of the nominal exchange rate and } \\
\text { foreign exchange reserves }\end{array}$ & 2 & 26 \\
Def 13 & $\begin{array}{l}\text { Weighted average of the real effective exchange rate, } \\
\text { interest rate and foreign exchange reserves }\end{array}$ & 2 & 113 \\
\cline { 2 - 4 } & & & \\
\hline
\end{tabular}

\section{Table 6.3: Exchange Market Pressure Index Based Currency Crisis Definitions with Varying Standard Deviation Multiplier:}

\begin{tabular}{|c|c|c|c|}
\hline & Variables in EMP index & $\begin{array}{l}\text { Multiplier of the } \\
\text { Standard Deviation }\end{array}$ & $\begin{array}{c}\text { \# of Currency } \\
\text { Crisis }\end{array}$ \\
\hline Def 14 & $\begin{array}{l}\text { Weighted average of the nominal exchange rate, } \\
\text { interest rate and international reserves }\end{array}$ & 1 & 134 \\
\hline Def 15 & $\begin{array}{l}\text { Weighted average of the nominal exchange rate, } \\
\text { interest rate and international reserves }\end{array}$ & 1.5 & 74 \\
\hline Def 16 & $\begin{array}{l}\text { Weighted average of the nominal exchange rate, } \\
\text { interest rate and international reserves }\end{array}$ & 1.75 & 65 \\
\hline Def 17 & $\begin{array}{l}\text { Weighted average of the nominal exchange rate, } \\
\text { interest rate and international reserves }\end{array}$ & 2 & 64 \\
\hline Def 18 & $\begin{array}{l}\text { Weighted average of the nominal exchange rate, } \\
\text { interest rate and international reserves }\end{array}$ & 2.5 & 62 \\
\hline Def 19 & $\begin{array}{l}\text { Weighted average of the nominal exchange rate, } \\
\text { interest rate and international reserves }\end{array}$ & 2.75 & 59 \\
\hline Def 20 & $\begin{array}{l}\text { Weighted average of the nominal exchange rate, } \\
\text { interest rate and international reserves }\end{array}$ & 3 & 57 \\
\hline
\end{tabular}

The determination of probability thresholds is essential and worthemphasizing since prediction power of an EWS model is directly related with the chosen threshold values. In this chapter, for each of the 20 different crisis indicator used as a dependent variable we repeated the EWS estimation using the same set of explanatory variables found significant in Chapter 5 for the same country set and time period 1970-2010. The prediction probabilities for each model and for each country/year are compared to different sets of probability threshold levels beyond which a country is said to have a currency crisis. This prediction is then compared to 
the actual crisis experience. The cases where a crisis is predicted and a crisis occurred are correctly predicted crisis. The cases when a crisis is not predicted and no crisis happens are the correctly predicted non-crisis periods.

By doing this, we produce probability of a currency crisis for each country and each year using 20 different currency crisis definitions. Each prediction is a value from a continuous set of probability values. In order to decide whether this continuous value predicts a currency crisis or not, a threshold level beyond which a crisis is predicted needs to be chosen. For instance, if we choose $50 \%$ probability threshold level, and probability predicted is greater than $50 \%$, then the model predicts a currency crisis in this country for this period. If the probability predicted is less than $50 \%$, the model predicts there is no crisis. According to this criterion, in our sample we calculate all of the predicted crisis and compare them with the actual crisis episodes. Hence the threshold chosen is very important for the results of the currency crisis prediction. 


\section{Table 6.4: Prediction Powers according to Definitions, An Example for 50\% Probability Threshold Value ${ }^{18}$}

\begin{tabular}{|c|c|c|c|c|c|c|c|c|c|c|c|c|c|c|c|c|c|c|c|c|}
\hline \multirow[b]{3}{*}{${ }_{1}^{\text {Total Number of Currency Crises }}$} & \multicolumn{8}{|c|}{ Depreciation Rate Based Currency Crisis Definitions } & \multicolumn{5}{|c|}{$\begin{array}{l}\text { Exchange Market Pressure Index Based } \\
\text { Currency Crisis Definitions with Varying } \\
\text { Variables }\end{array}$} & \multicolumn{7}{|c|}{$\begin{array}{l}\text { Exchange Market Pressure Index Based Currency Crisis Definitions } \\
\text { with Varying Standard Deviation Multiplier }\end{array}$} \\
\hline & Def1 & Def2 & Def3 & Def4 & Def5 & Def6 & $\operatorname{Def} 7$ & Def8 & Def9 & Def10 & Def11 & Def12 & Def13 & Def14 & Def15 & Def16 & Def17 & Def18 & Def19 & Def20 \\
\hline & 187 & 116 & 82 & 41 & 138 & 87 & 66 & 42 & 106 & 122 & 213 & 26 & 113 & 134 & 74 & 65 & 64 & 62 & 59 & 57 \\
\hline $\begin{array}{l}\text { Correctly Predicted Currency } \\
\text { Crises Episodes }^{2}\end{array}$ & 118 & 78 & 57 & 24 & 88 & 59 & 44 & 24 & 72 & 78 & 116 & 14 & 77 & 69 & 41 & 44 & 43 & 40 & 40 & 39 \\
\hline $\begin{array}{l}\text { Total Number of the Missing } \\
\text { Crisis Episodes } \\
\text { The Ratio of the Correctly }\end{array}$ & 69 & 38 & 25 & 17 & 50 & 28 & 22 & 18 & 34 & 44 & 97 & 3 & 36 & 65 & 33 & 21 & 21 & 22 & 19 & 18 \\
\hline $\begin{array}{l}\text { Predicted Currency Crisis } \\
\text { Episodes }{ }^{4}\end{array}$ & $63.1 \%$ & $67.2 \%$ & $69.5 \%$ & $58.5 \%$ & $63.8 \%$ & $67.8 \%$ & $66.7 \%$ & $57.1 \%$ & $67.9 \%$ & $63.9 \%$ & $54.5 \%$ & $53.8 \%$ & $68.1 \%$ & $51.5 \%$ & $55.4 \%$ & $67.7 \%$ & $67.2 \%$ & $64.5 \%$ & $67.8 \%$ & $68.4 \%$ \\
\hline $\begin{array}{l}\text { Total Number of Non-Crises } \\
\text { Episodes }\end{array}$ & 2298 & 2369 & 2403 & 2426 & 2329 & 2380 & 2401 & 2425 & 2397 & 1469 & 1444 & 2324 & 1625 & 1619 & 1678 & 1688 & 1689 & 1694 & 1694 & 1695 \\
\hline $\begin{array}{l}\text { Correctly Predicted Non- } \\
\text { Currency Crises Episodes }{ }^{6}\end{array}$ & 1145 & 1180 & 1197 & 1001 & 1110 & 1017 & 992 & 989 & 1006 & 633 & 619 & 919 & 698 & 815 & 879 & 899 & 907 & 921 & 923 & 924 \\
\hline Total False Alarms $^{7}$ & 1153 & 1189 & 1206 & 1425 & 1219 & 1363 & 1409 & 1436 & 1391 & 726 & 825 & 1471 & 978 & 804 & 799 & 789 & 782 & 773 & 771 & 767 \\
\hline $\begin{array}{l}\text { The Ratio of the Correctly } \\
\text { Predicted Non-Currency Crisis } \\
\text { Episodes }\end{array}$ & $49.8 \%$ & $49.8 \%$ & $49.8 \%$ & $41.3 \%$ & $47.7 \%$ & $42.7 \%$ & $41.3 \%$ & $40.8 \%$ & $42.0 \%$ & $43.1 \%$ & $42.9 \%$ & $39.5 \%$ & $43.0 \%$ & $50.3 \%$ & $52.4 \%$ & $53.3 \%$ & $53.7 \%$ & $54.4 \%$ & $54.5 \%$ & $54.6 \%$ \\
\hline Prediction Power of the Model ${ }^{9}$ & $50.8 \%$ & $50.6 \%$ & $50.5 \%$ & $41.5 \%$ & $48.6 \%$ & $43.6 \%$ & $42.0 \%$ & $41.1 \%$ & $43.1 \%$ & $44.7 \%$ & $44.4 \%$ & $39.7 \%$ & $44.6 \%$ & $50.4 \%$ & $52.5 \%$ & $53.8 \%$ & $54.2 \%$ & $54.7 \%$ & $54.9 \%$ & $\mathbf{5 5 . 0} \%$ \\
\hline Type I Error ${ }^{10}$ & $36.9 \%$ & $32.8 \%$ & $30.5 \%$ & $41.5 \%$ & $36.2 \%$ & $32.2 \%$ & $33.3 \%$ & $42.9 \%$ & $32.1 \%$ & $36.1 \%$ & $45.5 \%$ & $46.2 \%$ & $31.9 \%$ & $48.5 \%$ & $44.6 \%$ & $32.3 \%$ & $32.8 \%$ & $35.5 \%$ & $32.2 \%$ & $31.6 \%$ \\
\hline Type II Error ${ }^{11}$ & $50.2 \%$ & $50.3 \%$ & $50.3 \%$ & $58.7 \%$ & $52.3 \%$ & $57.3 \%$ & $58.7 \%$ & $59.2 \%$ & $58.0 \%$ & $57.0 \%$ & $57.1 \%$ & $60.5 \%$ & $56.8 \%$ & $49.7 \%$ & $47.6 \%$ & $46.7 \%$ & $46.3 \%$ & $45.6 \%$ & $45.5 \%$ & $45.4 \%$ \\
\hline
\end{tabular}

1: Total number of the actual currency crisis episodes according to EWS models

7: Total Number of non- Currency Crises Episodes- Correctly Predicted non-Currency Crises Episodes

2: Total Number of the Correctly Predicted Currency Crisis Episodes at 50\% Probability Threshold

8: Correctly Predicted non-Currency Crises Episodes/ Total Number of non-Currency Crises Episodes

3: Total Number of Currency Crises Episodes-Correctly Predicted Currency Crises Episodes

9: Total Number of Correctly Predicted Currency Crisis and non-Currency Crisis Episodes/Total Number of Currency and non-Currency Crisis Episodes

4. Correctly Predicted Currency Crises Episodes/ Total Number of Currency Crises Episodes

10: Type 1 Error: Total Number of Missed Currency Crisis Episodes/ Total Number of Currency Crisis Episodes

5: Total number of the actual number of non-currency crisis episodes

11: Type 2 Error: Total false alarms/ Total Number of non- Currency Crises Episodes

6: Total Number of the Correctly Predicted non-Currency Crisis Episodes at 50\% Probability Threshold

${ }^{18}$ The $50 \%$ probability threshold is chosen for an example since this threshold is the most preferred by the Early Warning Systems literature. 


\subsection{Prediction Power Results at 50\% Probability Threshold}

As can be seen from the table 6.1, after choosing a probability threshold, it is possible to compare different crisis definitions in terms of their success of predicting a crisis. The first line of the table indicates the total number of the actual currency crisis episodes. Line 2 shows the total number of correctly predicted currency crisis episodes at the $50 \%$ probability threshold value. In line 3 , total number of the missing crisis episodes is given which is the difference between the total number of actual currency crisis and the correctly predicted currency crisis episodes. Line 4 gives the ratio of the correctly predicted currency crisis episodes within the total number of currency crisis episodes. Line 5 shows the actual number of the noncurrency crisis episodes. In line 6 , the total number of correctly predicted currency non-crisis episodes at the $50 \%$ probability threshold value is presented. In line 7 , the number of total false alarms is presented which is the difference between the total number of non-currency crisis episodes and the number of correctly predicted noncurrency crisis episodes. In line 8 , the ratio of correctly predicted non-currency crisis episodes within the total number of non-currency crisis episodes is given. In line 8, the prediction power of the models at $50 \%$ probability threshold level is shown which demonstrates the ratio of correctly predicted crisis and non-crisis episodes to total number of crisis and non-crisis episodes.

In line 10 and 11, Type 1 and Type 2 errors are presented. Type 1 error (no signal is issued and a crisis occurs), which is also referred as missing a crisis, gives the share of the total number of missing currency crisis episodes in the total number of currency crisis episodes. On the other hand, Type 2 error (a signal is issued but no crisis occurs), which is also referred as issuing a false alarm, gives the share of the number of false alarms in the total number of non-currency crisis episodes. 
According to the Type 1 and Type 2 Error results, at the 50\% probability threshold level, Type 1 error (no signal is issued and a crisis occurs) varies among $31 \%-43 \%$ and Type 2 error (a signal is issued but no crisis occurs) is $50 \%-59 \%$ for the depreciation rate based definition group. In this definition group, Def 6 gives the lowest Type 1 Error and Def 1 gives the lowest Type 2 Error. Furthermore, Def 8 reveals the highest Type 1 and Type 2 Errors among the group.

When EMP index based definition group with varying variables group is considered, it is seen that Type 1 error changes among $32 \%$ to $50 \%$ while Type 2 error is between $57 \%$ and $61 \%$. Within this definition group, Def 13 gives the lowest Type 1 Error and Type 2 Error. On the other hand, Def 12 gives the highest Type 1 Error and Type 2 Error.

For EMP index based currency crisis definitions with varying standard deviation multiplier, Type 1 error varies between $32 \%$ and $49 \%$ and Type 2 error varies between $45 \%$ and 50\%. Among this group, Def 20 reveals the lowest Type 1 and Type 2 Errors while Def 14 gives the highest Type 1 and Type 2 Errors. When considered this definition group, it is seen the definition with the highest standard deviation multiplier reveals the lowest Type 1 and Type 2 Errors while definition with the lowest standard deviation multiplier gives the highest values for both Errors. This is due to the reason that the exchange market pressure index separates the crisis and non-crisis periods according to the specified standard deviation multiplier. Accordingly, with increasing standard deviation multiplier, the number of currency crisis episodes decreases with increasing the number of missing crisis episodes. This situation causes an increase in the Type 1 Error. On the other hand, the number of non-currency crisis episodes increases with decreasing the number of false alarms which led to a decrease in the Type 2 Error. 
If $50 \%$ probability threshold value is taken into consideration, it is seen that different currency crisis definitions yield slightly different results. The variation on the total number of the currency crisis episodes shows the significant impact of currency crisis definitions. For instance, in depreciation rate based currency crisis definitions group, the total number of currency crisis episodes varies between 187 and 41 and the total number of non-currency crisis episodes between 2426 and 2298 . In the EMP index based currency crisis definitions with varying variables group the currency crisis episodes is between 213 and 26 and the number of non-currency crisis episodes vary between 1444 and 2397. In the EMP index based currency crisis definitions with varying standard deviation multiplier group, the total number of currency crisis episodes varies between 134 and 57 and the total number of noncurrency crisis episodes between 1619 and 1695. It is seen that the number of currency crisis episodes is decreasing and the number of non-currency crisis episodes are increasing with increasing standard deviation multiplier. For instance, according to Definition 14, which is constructed with the lowest standard deviation multiplier level, the total number of currency crisis episodes is 134 and this number falls to 57 for the Definition 20, which is constructed with the highest standard deviation multiplier value. Conversely, it is observed that the total number of non-crisis episodes increases with increasing standard deviation multiplier within this definition group. For Definition 14, while this number is 1619, it increases to 1695 for Definition $20^{19}$.

If we compare the ratio of the correctly predicted crisis and correctly predicted non-crisis episodes, it is seen that all the definitions that are based on deprecation rate are more successful in correctly predicting the crisis episodes than

\footnotetext{
${ }^{19}$ When the multiplier of the standard deviation is kept high, the exchange market pressure index determines lower number of crisis episodes and may miss several crisis episodes compared to lower standard deviation multiplier.
} 
correctly predicting the non-crisis episodes at $50 \%$ probability threshold value. For instance, Def 1 correctly predicts the currency crisis periods by $63 \%$ while this ratio decreases to $59 \%$ in correctly predicting the non-crisis periods. Conversely, according to definitions which are based on EMP index with varying variables, it is seen that they reveal better results in predicting the crisis episodes than non-crisis episodes. For instance, while Def 9 correctly predicts the non-crisis episodes by $43 \%$, it correctly predicts the non-crisis episodes by $68 \%$. Moreover, the same is valid for the definitions with EMP index with varying standard deviation multiplier. For instance, Definition 20 correctly predicts the non-crisis episodes by $55 \%$ while this ratio is $68 \%$ in predicting the crisis episodes.

If the prediction powers of the depreciation rate based crisis definitions, which gives the success rates of the EWS, it is seen that the best definition that yields the highest prediction power is the Def 1 with $50.8 \%$ followed by Def 2 and Def 3 with $50.6 \%$ and $50.2 \%$ respectively where the worst definition is the Def 8 with 41.1\%. When the definition conditions are considered it is seen that the Def 1, Def 2 and Def 3 are constructed only with the annual depreciation of domestic currency. Therefore, it is possible to say that annual depreciation rate of domestic currency is an adequate measure for defining the currency crisis and including additional conditions are not necessary.

In EMP index based currency crisis definition group with varying variables, the prediction power change among $39.7 \%$ to $44.7 \%$. The best definition regarding the prediction power is Def 10 with $44.7 \%$ followed by Def 13 with $44.6 \%$ and Def 11 with $44.4 \%$. According to the results of this definition group, it is observed that including the interest rate as a variable into the index increases the prediction power of the models. For instance, Def 9 and Def 12 are constructed without including 
interest rate into the index and as a result they reveal the worst prediction power among the group.

EMP based currency crisis definitions with varying standard deviation multiplier group reveals better prediction power results compared to other two groups. The prediction power of the crisis definitions vary among 50.4\% and 55\%. The best definition is found as the Def 20 while the worst one is Def 14 . We also observed that the prediction powers of the models are increasing with the increasing standard deviation multiplier. This is due to the reason that when the multiplier of the standard deviation is kept high, the index identifies less crisis episodes compared to lower standard deviation multiplier. Although EWS issues few false alarms with higher rate, it misses several crisis episodes (Comelli, 2014). Our analysis shows that increasing the multiplier of the standard deviation from 1 to 3 , indeed, increases the prediction power of the model by decreasing false alarms. However, although the total currency episodes is 134 for Definition 14 when the standard deviation multiplier is kept lowest, this number falls to 59 for Definition 20 when the multiplier of the standard deviation is increased to highest.

Another interesting finding is that the definitions with the highest Type 2 Errors reveal the lowest prediction powers. For instance, in depreciation rate based definition group, Def 8 gives the highest Type 2 Error and it is the worst model regarding the prediction powers. In EMP index based definition group, Def 12 has the highest Type 2 Error ratio and it is also the worst model among the group. The same is also true for the EMP index based definition group with varying standard deviation multiplier. Def 14 reveals the highest Type 2 Error with respect to the other definitions in this group and has the lowest prediction power. 
Consequently, Table 6.1 shows that, under at $50 \%$ threshold level, we can compare the prediction powers of the EWS models under different crisis definitions. We see that crisis definition creates significant impact on the success rates of the EWS models. However, the threshold choice too is a crucial point of an EWS since the aim of an Early Warning System is to predict the crisis and non-crisis episodes as correctly as possible.

\subsection{Alternative Probability Thresholds}

The prediction power of an EWS model is highly dependent to the correctly predicted crisis and non-crisis periods and one of the determining factor for the prediction powers of EWS models is the probability threshold (cut-off) value. Therefore, the choice of probability threshold is important since it discriminates the predicted crisis episodes against predicted tranquil periods in order to shift the estimated output crisis probabilities into crisis forecasts (Candelon et al., 2000).

In the literature, most of the previous studies on Early Warning Systems choose one or two probability threshold levels to forecast the models in almost all of them the conclusion is that the prediction power is not sensitive to probability threshold values. Here, in order to examine whether this claim is true or not, we would like to evaluate how predictive power of EWS models change according to the different threshold values. This section discusses the success rates of the EWS model under alternative crisis definitions and threshold levels by presenting Type 1 Error, Type 2 Error and the prediction power of the models.

In the previous case (Table 6.1 ), we analyze the $50 \%$ probability threshold level for 20 different currency crisis definitions. Now, we are going to show how the results change according to the alternative threshold levels. We change the threshold levels between $1 \%$ and $95 \%(1,2.5,5,10,25,50,75,80,85,90$, and 95\%) and 
reevaluate the EWS's success for each of these crisis definitions under 11 different threshold levels. Here to be able to evaluate the success of the EWS model, we present the prediction power (total number of correctly predicted currency crisis plus non-currency crisis episodes/total number of currency plus non-currency crisis episodes) and Type 1 and Type 2 Errors of the models according to different crisis definitions and different probability threshold levels.

Table 6.5: Type 1 Errors the Model according to different Crisis Definitions and different Probability Thresholds

\begin{tabular}{|c|c|c|c|c|c|c|c|c|c|c|c|}
\hline & $\begin{array}{c}\text { Probability } \\
\text { Threshold } \\
1 \% \\
\end{array}$ & $\begin{array}{c}\text { Probability } \\
\text { Threshold } \\
2.5 \% \\
\end{array}$ & $\begin{array}{c}\text { Probability } \\
\text { Threshold } \\
\text { 5\% } \\
\end{array}$ & $\begin{array}{c}\text { Probability } \\
\text { Threshold } \\
10 \% \\
\end{array}$ & $\begin{array}{c}\text { Probability } \\
\text { Threshold } \\
25 \% \\
\end{array}$ & $\begin{array}{c}\begin{array}{c}\text { Probability } \\
\text { Threshold } \\
\mathbf{5 0 \%}\end{array} \\
\end{array}$ & $\begin{array}{c}\text { Probability } \\
\text { Threshold } \\
75 \% \\
\end{array}$ & $\begin{array}{c}\text { Probability } \\
\text { Threshold } \\
\mathbf{8 0 \%} \\
\end{array}$ & $\begin{array}{c}\text { Probability } \\
\text { Threshold } \\
85 \% \\
\end{array}$ & $\begin{array}{c}\text { Probability } \\
\text { Threshold } \\
\mathbf{9 0 \%} \\
\end{array}$ & $\begin{array}{c}\text { Probability } \\
\text { Threshold } \\
\mathbf{9 5 \%} \\
\end{array}$ \\
\hline Def 1 & $0.5 \%$ & $13.9 \%$ & $22.5 \%$ & $28.9 \%$ & $35.8 \%$ & $36.9 \%$ & $36.9 \%$ & $36.9 \%$ & $36.9 \%$ & $36.9 \%$ & $36.9 \%$ \\
\hline Def 2 & $4.3 \%$ & $10.3 \%$ & $13.8 \%$ & $22.4 \%$ & $28.4 \%$ & $32.8 \%$ & $32.8 \%$ & $32.8 \%$ & $32.8 \%$ & $32.8 \%$ & $32.8 \%$ \\
\hline Def 3 & $3.7 \%$ & $9.8 \%$ & $11.0 \%$ & $15.9 \%$ & $25.6 \%$ & $30.5 \%$ & $30.5 \%$ & $30.5 \%$ & $30.5 \%$ & $30.5 \%$ & $30.5 \%$ \\
\hline Def 4 & $2.4 \%$ & $9.8 \%$ & $24.4 \%$ & $34.1 \%$ & $41.5 \%$ & $41.5 \%$ & $41.5 \%$ & $41.5 \%$ & $41.5 \%$ & $41.5 \%$ & $41.5 \%$ \\
\hline Def 5 & $0.7 \%$ & $8.7 \%$ & $18.8 \%$ & $28.3 \%$ & $34.8 \%$ & $36.2 \%$ & $36.2 \%$ & $36.2 \%$ & $36.2 \%$ & $36.2 \%$ & $36.2 \%$ \\
\hline Def 6 & $2.3 \%$ & $4.6 \%$ & $9.2 \%$ & $17.2 \%$ & $25.3 \%$ & $32.2 \%$ & $32.2 \%$ & $32.2 \%$ & $32.2 \%$ & $32.2 \%$ & $32.2 \%$ \\
\hline Def 7 & $3.0 \%$ & $6.1 \%$ & $7.6 \%$ & $15.2 \%$ & $27.3 \%$ & $33.3 \%$ & $33.3 \%$ & $33.3 \%$ & $33.3 \%$ & $33.3 \%$ & $33.3 \%$ \\
\hline Def 8 & $4.8 \%$ & $11.9 \%$ & $26.2 \%$ & $35.7 \%$ & $42.9 \%$ & $42.9 \%$ & $42.9 \%$ & $42.9 \%$ & $42.9 \%$ & $42.9 \%$ & $42.9 \%$ \\
\hline Def 9 & $0.9 \%$ & $8.5 \%$ & $18.9 \%$ & $24.5 \%$ & $32.1 \%$ & $32.1 \%$ & $32.1 \%$ & $32.1 \%$ & $32.1 \%$ & $32.1 \%$ & $32.1 \%$ \\
\hline Def 10 & $2.5 \%$ & $9.0 \%$ & $19.7 \%$ & $28.7 \%$ & $35.2 \%$ & $36.1 \%$ & $36.1 \%$ & $36.1 \%$ & $36.1 \%$ & $36.1 \%$ & $36.1 \%$ \\
\hline Def 11 & $1.9 \%$ & $12.7 \%$ & $33.3 \%$ & $47.4 \%$ & $50.2 \%$ & $50.2 \%$ & $50.2 \%$ & $50.2 \%$ & $50.2 \%$ & $50.2 \%$ & $50.2 \%$ \\
\hline Def 12 & $1.7 \%$ & $9.8 \%$ & $23.8 \%$ & $31.8 \%$ & $43.8 \%$ & $46.2 \%$ & $46.2 \%$ & $46.2 \%$ & $46.2 \%$ & $46.2 \%$ & $46.2 \%$ \\
\hline Def 13 & $0.9 \%$ & $8.8 \%$ & $16.8 \%$ & $26.5 \%$ & $31.9 \%$ & $31.9 \%$ & $31.9 \%$ & $31.9 \%$ & $31.9 \%$ & $31.9 \%$ & $31.9 \%$ \\
\hline Def 14 & $0.7 \%$ & $7.5 \%$ & $25.4 \%$ & $35.8 \%$ & $35.8 \%$ & $48.5 \%$ & $48.5 \%$ & $48.5 \%$ & $48.5 \%$ & $48.5 \%$ & $48.5 \%$ \\
\hline Def 15 & $2.7 \%$ & $6.7 \%$ & $14.7 \%$ & $24.0 \%$ & $30.7 \%$ & $44.6 \%$ & $44.6 \%$ & $44.6 \%$ & $44.6 \%$ & $44.6 \%$ & $44.6 \%$ \\
\hline Def 16 & $3.1 \%$ & $6.2 \%$ & $10.8 \%$ & $16.9 \%$ & $27.7 \%$ & $32.3 \%$ & $32.3 \%$ & $32.3 \%$ & $32.3 \%$ & $32.3 \%$ & $32.3 \%$ \\
\hline Def 17 & $3.1 \%$ & $6.3 \%$ & $10.9 \%$ & $17.2 \%$ & $28.1 \%$ & $32.8 \%$ & $32.8 \%$ & $32.8 \%$ & $32.8 \%$ & $32.8 \%$ & $32.8 \%$ \\
\hline Def 18 & $8.1 \%$ & $11.3 \%$ & $17.7 \%$ & $22.6 \%$ & $32.3 \%$ & $35.5 \%$ & $35.5 \%$ & $35.5 \%$ & $35.5 \%$ & $35.5 \%$ & $35.5 \%$ \\
\hline Def 19 & $3.4 \%$ & $6.8 \%$ & $11.9 \%$ & $18.6 \%$ & $28.8 \%$ & $27.6 \%$ & $27.6 \%$ & $27.6 \%$ & $27.6 \%$ & $27.6 \%$ & $27.6 \%$ \\
\hline Def 20 & $3.2 \%$ & $6.5 \%$ & $11.3 \%$ & $17.7 \%$ & $29.0 \%$ & $36.8 \%$ & $36.8 \%$ & $36.8 \%$ & $36.8 \%$ & $36.8 \%$ & $36.8 \%$ \\
\hline
\end{tabular}

Author's own calculations

In the context of Type 1 Error, when the first 8 currency crisis definitions are considered, at $1 \%$ probability threshold level, Type 1 Error varies between $1 \%$ and 5\%. At $2.5 \%$ threshold value, Type 1 Error increases to 5\%-14\% and when $50 \%$ threshold value is set, Type1 Error increases to $31 \%-43 \%$. 
The divergence of Type 1 Error according to currency crisis definitions 9-13, is between $1 \%$ and $3 \%$ at the $1 \%$ threshold level. However, at the $50 \%$ probability threshold, the range of the Type 1 Error is between $32 \%$ and $50 \%$.

At the $1 \%$ threshold level, according to EMP index based currency crisis definitions with varying standard deviation multiplier (14-20), Type 1 Error is placed among $1 \%$ to $8 \%$. When we investigate the errors at $50 \%$ threshold level, Type 1 Error varies between $28 \%$ and $49 \%$ for all definitions in the group of EMP index based currency crisis definitions with varying standard deviation multiplier.

Table 6.6: Type 2 Errors the Model according to different Crisis Definitions and different Probability Thresholds

\begin{tabular}{|c|c|c|c|c|c|c|c|c|c|c|c|}
\hline & $\begin{array}{c}\text { Probability } \\
\text { Threshold } \\
1 \%\end{array}$ & $\begin{array}{c}\text { Probability } \\
\text { Threshold } \\
2.5 \% \\
\end{array}$ & $\begin{array}{c}\text { Probability } \\
\text { Threshold } \\
5 \%\end{array}$ & $\begin{array}{c}\text { Probability } \\
\text { Threshold } \\
10 \%\end{array}$ & $\begin{array}{c}\text { Probability } \\
\text { Threshold } \\
\text { 25\% }\end{array}$ & $\begin{array}{c}\text { Probability } \\
\text { Threshold } \\
\mathbf{5 0 \%}\end{array}$ & $\begin{array}{c}\text { Probability } \\
\text { Threshold } \\
\mathbf{7 5 \%} \\
\end{array}$ & $\begin{array}{c}\text { Probability } \\
\text { Threshold } \\
80 \% \\
\end{array}$ & $\begin{array}{c}\text { Probability } \\
\text { Threshold } \\
85 \%\end{array}$ & $\begin{array}{c}\text { Probability } \\
\text { Threshold } \\
\text { 90\% }\end{array}$ & $\begin{array}{c}\text { Probability } \\
\text { Threshold } \\
\mathbf{9 5 \%}\end{array}$ \\
\hline Def 1 & $90.1 \%$ & $81.5 \%$ & $70.4 \%$ & $61.3 \%$ & $50.8 \%$ & $50.2 \%$ & $50.2 \%$ & $50.2 \%$ & $50.2 \%$ & $50.2 \%$ & $50.2 \%$ \\
\hline Def 2 & $84.1 \%$ & $77.7 \%$ & $69.0 \%$ & $57.8 \%$ & $51.4 \%$ & $50.3 \%$ & $50.2 \%$ & $50.2 \%$ & $50.2 \%$ & $50.2 \%$ & $50.2 \%$ \\
\hline Def 3 & $82.0 \%$ & $76.8 \%$ & $68.8 \%$ & $57.9 \%$ & $51.7 \%$ & $50.3 \%$ & $50.2 \%$ & $50.2 \%$ & $50.2 \%$ & $50.2 \%$ & $50.2 \%$ \\
\hline Def 4 & $88.5 \%$ & $80.5 \%$ & $71.0 \%$ & $62.2 \%$ & $58.9 \%$ & $58.7 \%$ & $58.7 \%$ & $58.7 \%$ & $58.7 \%$ & $58.7 \%$ & $58.7 \%$ \\
\hline Def 5 & $91.7 \%$ & $82.8 \%$ & $70.7 \%$ & $60.8 \%$ & $57.4 \%$ & $52.3 \%$ & $52.3 \%$ & $52.3 \%$ & $52.3 \%$ & $52.3 \%$ & $52.3 \%$ \\
\hline Def 6 & $83.4 \%$ & $78.1 \%$ & $69.3 \%$ & $60.6 \%$ & $58.1 \%$ & $57.3 \%$ & $57.3 \%$ & $57.3 \%$ & $57.3 \%$ & $57.3 \%$ & $57.3 \%$ \\
\hline Def 7 & $82.9 \%$ & $77.4 \%$ & $69.1 \%$ & $62.1 \%$ & $58.8 \%$ & $58.7 \%$ & $58.7 \%$ & $58.7 \%$ & $58.7 \%$ & $58.7 \%$ & $58.7 \%$ \\
\hline Def 8 & $86.6 \%$ & $79.8 \%$ & $70.4 \%$ & $62.5 \%$ & $58.8 \%$ & $59.2 \%$ & $59.2 \%$ & $59.2 \%$ & $59.2 \%$ & $59.2 \%$ & $59.2 \%$ \\
\hline Def 9 & $71.7 \%$ & $61.5 \%$ & $56.0 \%$ & $53.0 \%$ & $49.2 \%$ & $58.0 \%$ & $55.4 \%$ & $55.4 \%$ & $55.4 \%$ & $55.4 \%$ & $55.4 \%$ \\
\hline Def 10 & $99.1 \%$ & $75.6 \%$ & $55.9 \%$ & $51.9 \%$ & $48.4 \%$ & $56.9 \%$ & $56.9 \%$ & $56.9 \%$ & $56.9 \%$ & $56.9 \%$ & $56.9 \%$ \\
\hline Def 11 & $99.4 \%$ & $76.5 \%$ & $54.0 \%$ & $49.7 \%$ & $50.1 \%$ & $57.1 \%$ & $58.5 \%$ & $58.5 \%$ & $58.5 \%$ & $58.5 \%$ & $58.5 \%$ \\
\hline Def 12 & $97.2 \%$ & $74.2 \%$ & $56.3 \%$ & $47.6 \%$ & $48.3 \%$ & $60.5 \%$ & $60.5 \%$ & $60.5 \%$ & $60.5 \%$ & $60.5 \%$ & $60.5 \%$ \\
\hline Def 13 & $65.4 \%$ & $59.7 \%$ & $55.8 \%$ & $46.5 \%$ & $48.8 \%$ & $57.0 \%$ & $60.2 \%$ & $60.2 \%$ & $60.2 \%$ & $60.2 \%$ & $60.2 \%$ \\
\hline Def 14 & $90.2 \%$ & $67.3 \%$ & $59.3 \%$ & $50.8 \%$ & $57.4 \%$ & $49.7 \%$ & $49.7 \%$ & $49.7 \%$ & $49.7 \%$ & $49.7 \%$ & $49.7 \%$ \\
\hline Def 15 & $73.9 \%$ & $66.6 \%$ & $59.3 \%$ & $51.5 \%$ & $57.3 \%$ & $47.6 \%$ & $47.6 \%$ & $47.6 \%$ & $47.6 \%$ & $47.6 \%$ & $47.6 \%$ \\
\hline Def 16 & $74.4 \%$ & $66.6 \%$ & $59.1 \%$ & $59.1 \%$ & $57.3 \%$ & $46.7 \%$ & $46.7 \%$ & $46.7 \%$ & $46.7 \%$ & $46.7 \%$ & $46.7 \%$ \\
\hline Def 17 & $74.2 \%$ & $66.0 \%$ & $59.1 \%$ & $59.3 \%$ & $57.3 \%$ & $46.3 \%$ & $46.3 \%$ & $46.3 \%$ & $46.3 \%$ & $46.3 \%$ & $46.3 \%$ \\
\hline Def 18 & $73.7 \%$ & $66.0 \%$ & $59.1 \%$ & $59.3 \%$ & $57.3 \%$ & $45.6 \%$ & $45.6 \%$ & $45.6 \%$ & $45.6 \%$ & $45.6 \%$ & $45.6 \%$ \\
\hline Def 19 & $73.5 \%$ & $65.8 \%$ & $51.5 \%$ & $59.1 \%$ & $49.8 \%$ & $45.5 \%$ & $45.5 \%$ & $45.5 \%$ & $45.5 \%$ & $45.5 \%$ & $45.5 \%$ \\
\hline Def 20 & $73.1 \%$ & $62.0 \%$ & $50.8 \%$ & $59.1 \%$ & $49.6 \%$ & $45.4 \%$ & $45.4 \%$ & $45.4 \%$ & $45.4 \%$ & $45.4 \%$ & $45.4 \%$ \\
\hline
\end{tabular}

In the context of Type 2 Error, in the depreciation rate based currency crisis definitions group, at $1 \%$ probability threshold level, Type 2 Error varies between 
$82 \%$ and $92 \%$. At $2.5 \%$ threshold value, Type 2 Error falls to $77 \%-82 \%$. Moreover, when $50 \%$ threshold value is set, Type 2 Error decreases to $50-59 \%$.

In the EMP index based currency crisis definition group with varying variables, at $1 \%$ threshold level, Type 2 Error is between $65 \%$ and $99 \%$. However, at the $50 \%$ probability threshold, Type 2 Error varies around $55 \%$ and $61 \%$.

According to EMP based currency crisis definitions with varying standard deviation multiplier (14-20), Type 2 Error is between $49 \%$ and $50 \%$ at $1 \%$ threshold level. In this definition group, it is seen that the Type 2 Errors are decreasing with the increasing standard deviation multiplier.

In all currency crisis definitions after $50 \%$ probability threshold value, Type 1 Errors and Type 2 Errors do not change since the number of crisis and non-crisis episodes and also the correctly predicted crisis and non-crisis episodes do not change.

By looking to Table 6.3 and Table 6.4, it is observed that Type 1 Error increases with the increasing threshold value and Type 2 decreases with increasing threshold value until the $50 \%$ threshold value and at this threshold the average of these errors are minimized. In the literature it is explained that higher probability thresholds reveals higher probability of Type 1 Error and lower the probability of Type 2 Error. If a higher threshold is set, Early Warning System tends to miss some of the crisis episodes and thus does not give any signal even if there is a crisis (Type 1 Error). By contrast, if a lower threshold is identified, this time the system tends to lead a number of false signals (Type 2 Error). In other words, higher probability threshold reveals higher probability of Type 1 Errors and lower the probability of Type 2 Errors, vice versa. Therefore, our findings are as expected according to the literature. Some the studies in the literature say that it is important to identify a 
probability threshold which minimizes the number of non-signaled crises and false alarms (Borio and Drehmann, 2009) and our work identifies 50\% as this level. However, the cost of each Type 1 and Type 2 Error may be different for a policymaker.

Table 6.7: Prediction Powers of the Model according to different Crisis Definitions and different Probability Thresholds

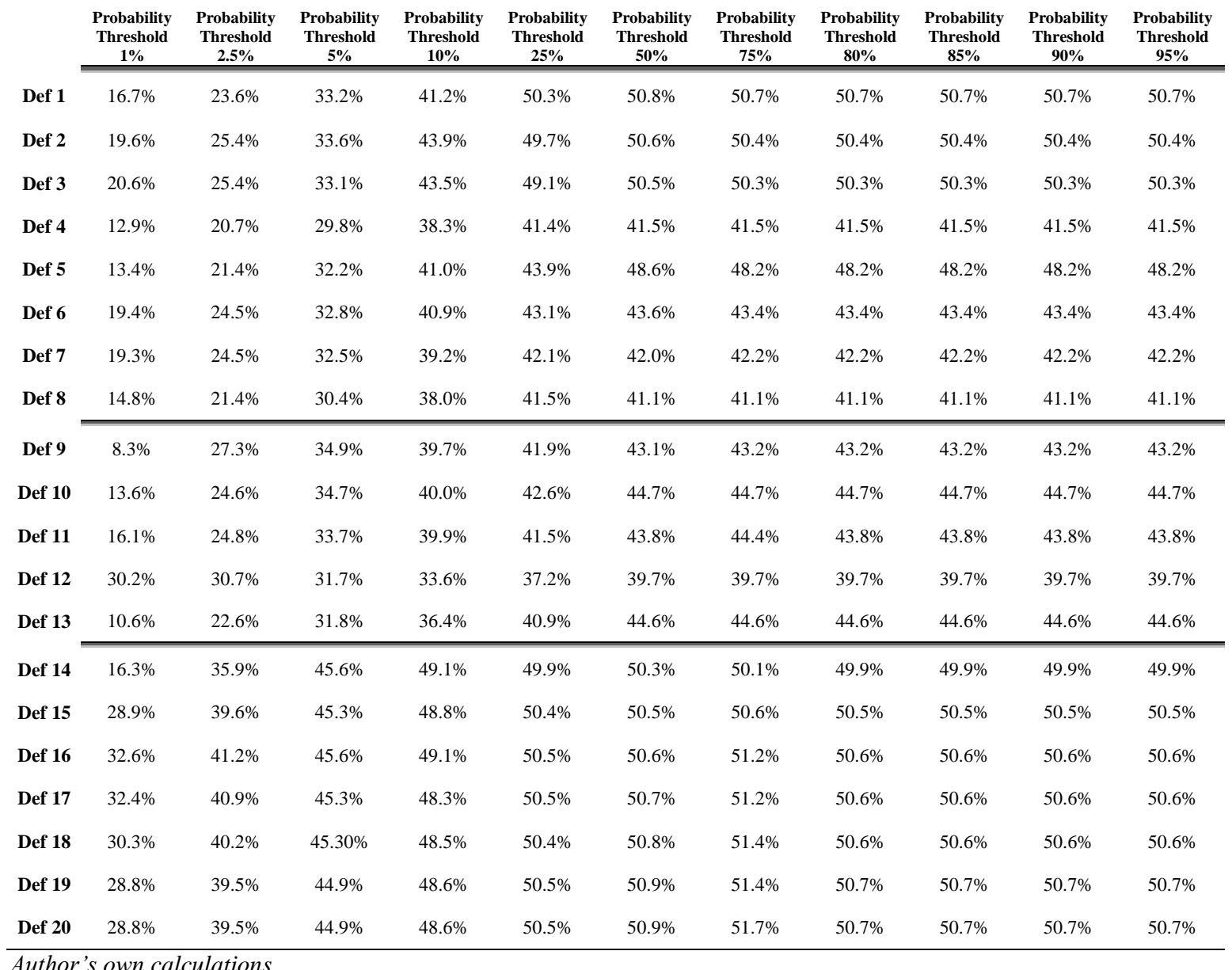

In Table 6.2, the prediction powers of the different crisis indicators are shown for 11 different probability threshold values. According to the table, it is seen that for all 20 currency crisis definitions the prediction powers are quite low at the $1 \%$ threshold level. For the first definition group (definitions 1-8) the prediction power varies between 13\%-21\%; for the second definition group $8 \%-30 \%$ and the third definition group $16 \%-33 \%$. 
As we expect, the prediction powers of the crisis indicators increase with higher probability threshold values. However, the increase in prediction powers is observed until the $50 \%$ threshold value. If the threshold value gets higher values than $50 \%$, the prediction powers of the models remain more or less around the same values. The relationships between threshold values and prediction powers for definition groups are plotted in Figure $6.3^{20}$.

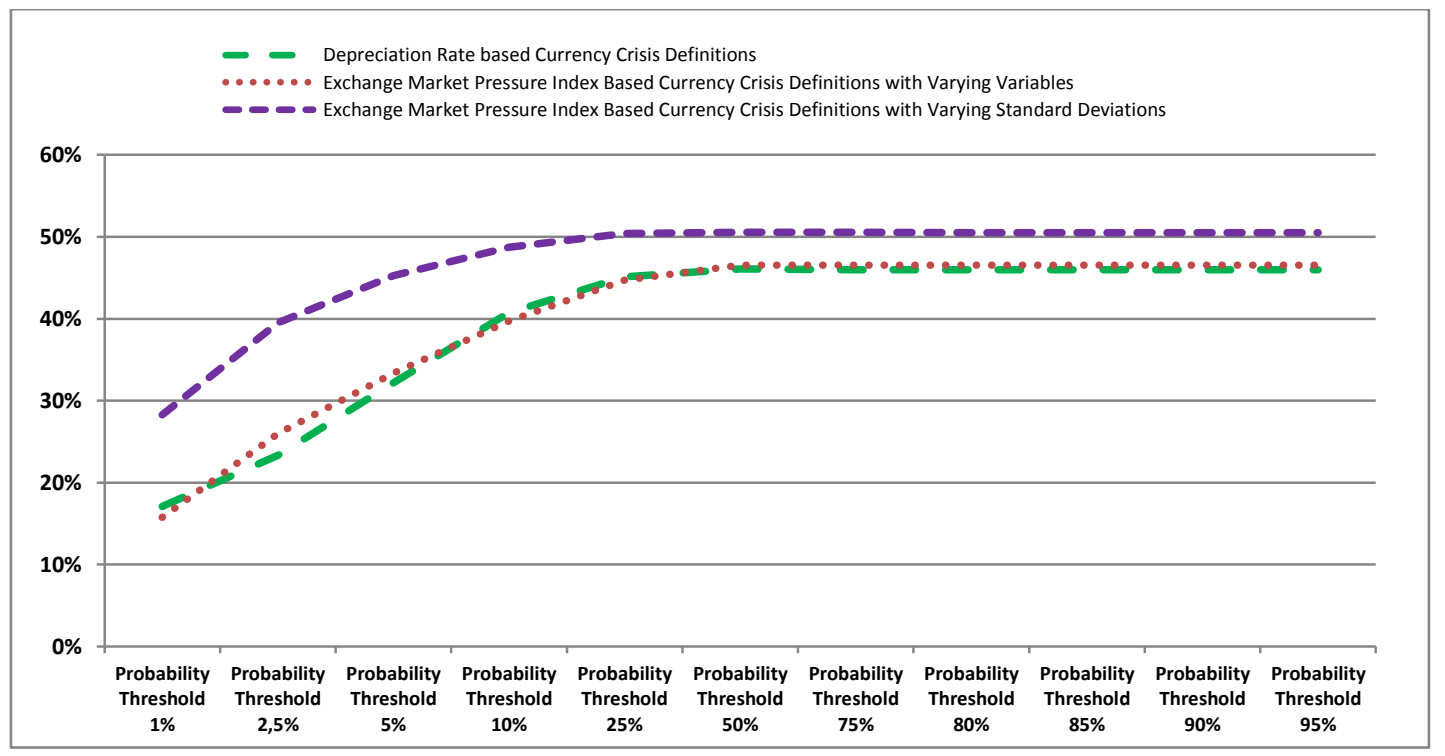

\section{Figure 6.1: Average Prediction Powers and Probability Threshold Values for Definition Groups}

As the above graph confirms, increasing probability thresholds have a positive impact on prediction powers of the currency crisis models until the $50 \%$ probability threshold value. After this level of threshold, the prediction powers of the models are more or less constant.

One of the interesting results of our analysis is as follows: The prediction powers of all 20 different currency crisis definitions increase until the 50\%

${ }^{20}$ The prediction powers of the models are averaged. 
probability threshold. However, this increase is not uniform for all definitions meaning that they are not increasing in the same amount for a given change in the threshold level. For instance, while at $1 \%$ probability threshold value Def 3 gives the most successful result compared to the remaining models in the first definition group, when the threshold level is increased to $50 \%$, Def 3 drops to the third place with $50.5 \%$ prediction power. Furthermore, in the second definition group, although Definition 12 has the highest prediction power at $1 \%$ threshold, at $50 \%$ level it falls to the last place in the ranking. Moreover, the same is valid for Definition 16, which is the best model at $1 \%$ level, at $50 \%$ threshold now ranks at lower levels.

When the overall the results are compared among definitions, it is seen that EMP index based currency crisis definitions with varying standard deviation multiplier are more successful in terms of correctly predicted crisis and non-crisis episodes. The worst definition group comes up as the depreciation rate based currency crisis definitions. Hence, we conclude that while constructing an EWS model, more comprehensive crisis definitions are necessary.

Considering the definitions $14-20$, it is found that with decreasing standard deviation multiplier, the prediction powers of the definitions decrease too. In the Early Warning System literature, the optimal standard deviation multiplier value is considered as 3. In the EWS methodology, the decision of standard deviation multiplier is important. The results from the predictions also points out to this.

As a result, in this chapter, we investigated the impacts of different versions of definition methods and thresholds values on the prediction powers of Early Warning System models for the in-sample (1970-2010) period. Our results empirically proved that crisis definitions and threshold choices significantly affect the prediction powers of the EWS models. According to that, while EMP index based 
definition is shown to be a better predictor compared to depreciation based definitions, we also find that EMP index gives better results when its standard deviation multiplier is changed not the explanatory variables. Furthermore, we find that all tested models give their best results at the 50\% threshold level. This led us to conclude that the optimal threshold level for EWS models is $50 \%$ if the costs of either Type 1 or Type 2 Error are thought to be the same for the decision maker.

In the next section, we also conducted a robustness test in the way of including some crucial balance of payments variables according to the literature (even if they revealed insignificant results in the first step of our analysis). The main purpose of the robustness test is to test whether including these important variables change our prediction power results.

\subsection{Robustness Tests}

We devote this section to a series of robustness tests conducted on the empirical results of in-sample forecasting performance. Here the sample includes the period of 1970 and 2010. The evaluation of the forecasting performance is repeated for 20 different currency crisis definitions with the same country set. For each EWS model prediction powers are tested for 11 different probability threshold levels as is used in the Section 6.3.

For our robustness tests, we follow the study of Bussiere and Fratzscher (2002) and perform the forecast analysis by including additional explanatory variables into our model. For this purpose, we, first, add one balance of payments variable, specifically exports of goods and services (annual \% growth) that is widely found significant in the currency crisis literature but omitted in our analysis since the coefficients of this variable was found to be insignificant during the first round of 
estimations. In addition to percentage growth of exports of goods and services, we had included other balance of payments variables such as the ratio of foreign direct investments to GDP and portfolio equity net inflows in the initial estimations but found insignificant coefficients in all model versions. Hence, these balance of payments variables were excluded from models that are used to analyze forecasting performances.

Although we could have added other insignificant variables that were found insignificant in Chapter 5 into our robustness test, we preferred balance of payments variables as in the literature current account balances are often and widely associated with the currency crisis. Therefore, we believe it is important to analyze whether including balance of payments variables can change our forecast results. For this purpose, we renew our analysis that we conducted in Section 6.3 by adding exports of goods and services (annual \% growth). Furthermore we have also included variables such as the ratio of foreign direct investments to GDP and portfolio equity net inflows as explanatory variables to the models where we used 20 different currency crisis indicators as the dependent variables. In doing so, we are able to see how solid our model and our in-sample conclusions are and whether the new variables change the prediction powers of alternative EWS models.

Exports of Goods and Services (Annual \% Growth): As a current account indicator, export growth is marked as having considerable explanatory power on the issue of currency crisis in EWS models (Vlaar (1999), Berg and Pattillo (2000)). Therefore, although this variable was not included to the initial analysis, it is added to the robustness test of this study in order to test whether it changes the forecast results. 
As we did not use this variable for our estimation analysis in Chapter 5, we first start with testing the significance of the annual growth of exports of goods and services. Our analysis shows that the percentage of the annual growth of exports of goods and services is not a significant indicator of a currency crisis under either the depreciation rate based currency crisis definitions or, EMP index based definition with different mix of explanatory variables. The insignificance continued even under different standard deviation multipliers used in the computation of the EMP index ${ }^{21}$.

According to the forecast results, including this variable into the regression does not change the total crisis and non-crisis episodes (since the dependent variables are the same) ${ }^{22}$. Furthermore, the ratio of correctly predicted crisis and non-crisis episodes is more or less the same with the actual regression that we conducted without the annual growth of exports of goods and services. Consequently, including annual growth of exports of goods and services does not significantly increase the predictive power of the EWS model that is constructed with alternative currency crisis definitions.

The Ratio of Foreign Direct Investments to GDP: Although in our initial analysis in Chapter 5, the foreign direct investments to GDP ratio is added to the regression and reveal insignificant results, we still wanted to do robustness tests to see its impact on the prediction power of the EWS model. In the literature, it is argued that the size and the nature of capital flows matter for currency crises. Moreover, there is a general perception that FDI is a better option compared to portfolio investment for the domestic economy (Bussiere and Fratzscher, 2002). In many studies, the ratio of foreign direct investments to GDP ratio is found as essential for predicting the currency crises (Berg and Pattillo (2000), Rydqvist (2005)).

\footnotetext{
${ }^{21}$ Empirical results of robustness test is given in Appendix A3

${ }^{22}$ The prediction power results of the robustness test at $50 \%$ probability threshold level for the model with the annual growth of exports of goods and services are given in Table 1 in Appendix A4
} 
Our results show that including the ratio of foreign direct investments to GDP ratio does not change the total number of crisis and non-crisis episodes (since the dependent variables are the same $)^{23}$. However, it is seen that the ratio of correctly predicted crisis and non-crisis episodes decrease in the rage of $1 \%-2 \%$ for all definitions. Thus, adding the ratio of foreign direct investments to GDP ratio into the regression does not help to predict more crises.

Portfolio Equity Net Inflows: As the foreign direct investments to GDP ratio although we found that portfolio equity net inflows is not a significant indicator of currency crisis in Chapter 5. However, to test the robustness of our analysis, we include it into our model to see the difference it creates on the prediction power of the model.

Our results reveal that adding portfolio equity net inflows into the regression does not have an impact on the total number of crisis and non-crisis episodes since the dependent variables are the same ${ }^{24}$. Moreover, the ratios of correctly predicted crisis and non-crisis episodes are more or less the same as in the actual regression. Therefore, we conclude that adding portfolio equity net inflows has no contribution to the predictive power of the EWS model.

\footnotetext{
${ }^{23}$ The prediction power results of the robustness test at $50 \%$ probability threshold level for the model with the ratio of foreign direct investment to GDP are given in Table 2 in Appendix A4

${ }^{24}$ The prediction power results of the robustness test at $50 \%$ probability threshold level for the model with the portfolio equity net inflows are given in Table 3 in Appendix A4
} 


\section{CHAPTER 7}

\section{THE ANALYSIS OF EWS PREDICTION ABILITY WITH OUT- OF-SAMPLE FORECAST}

In the previous chapter, we conducted an in-sample prediction and evaluate the prediction performance of the EWS model under 20 currency crisis definitions and 11 different threshold levels for the time period 1970 to 2010. In this chapter, since the policy maker would be interested in the out-of-sample forecast, we restrict our estimation sample to 1970-1994 and forecast sample to 1995-2010. For this aim, the estimations and forecasts are conducted with the same set of explanatory variables, econometric method and country set for 20 alternative crisis indicators that are used as the dependent variables.

\subsection{Alternative Crisis Definitions}

The results of the out-of-sample forecasts (1995-2010) for each crisis definitions at $50 \%$ threshold level are reported in Table $7.1^{25}$.

\footnotetext{
${ }^{25}$ The empirical results of the estimation of the out-of-sample (1970-1994) are given in Table 1 in Appendix 5.
} 


\section{Table 7.1: Out-of-Sample Results of the Model according to different Currency Crisis Definitions ${ }^{26}$}

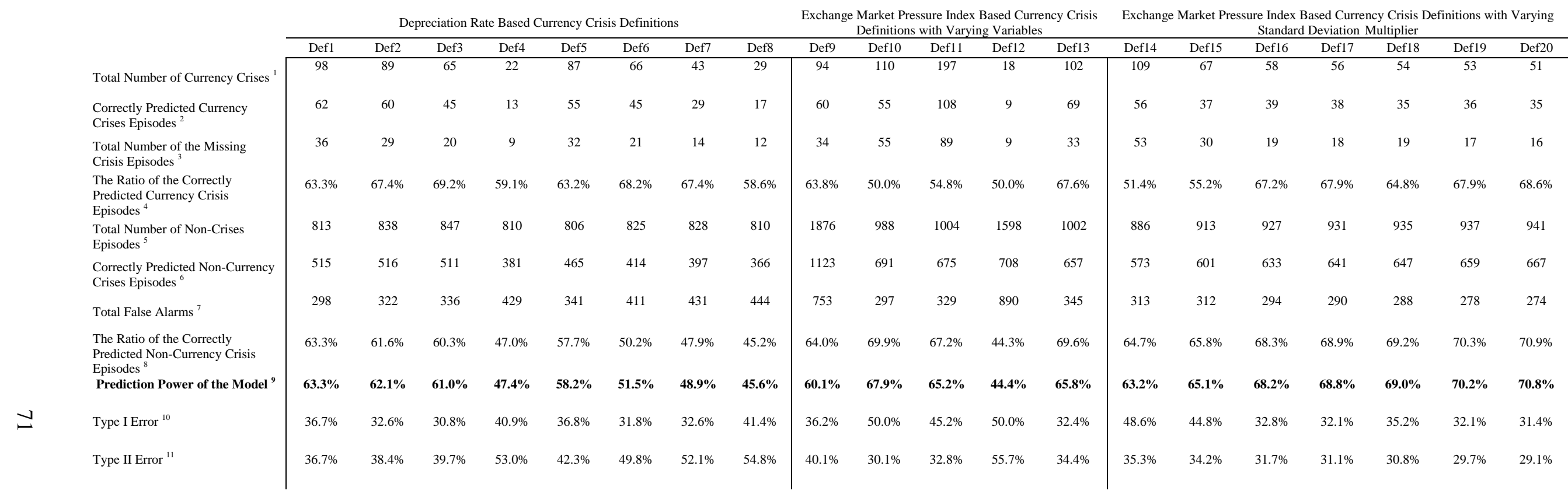

1: Total number of the actual currency crisis episodes according to EWS models

7: Total Number of non- Currency Crises Episodes- Correctly Predicted non-Currency Crises Episodes

2: Total Number of the Correctly Predicted Currency Crisis Episodes according to EWS models under 50\% Probability Threshold

8: Correctly Predicted non-Currency Crises Episodes/ Total Number of non-Currency Crises Episodes

3: Total Number of Currency Crises Episodes-Correctly Predicted Currency Crises Episodes

9: Total Number of Correctly Predicted Currency Crisis and non-Currency Crisis Episodes/Total Number of Currency and non-Currency Crisis Episodes

10: Type 1 Error: Total Number of Missed Currency Crisis Episodes/ Total Number of Currency

4: Correctly Predicted Currency Crises Episodes/ Total Number of Currency Crises Episodes

11: Type 2 Error: Total false alarms/ Total Number of non- Currency Crises Episodes

6: Total Number of the Correctly Predicted non-Currency Crisis Episodes according to EWS models under 50\% Probability Threshold

${ }^{26}$ The 50\% probability threshold is chosen to conduct the out-of-sample since this threshold is the most preferred by the Early Warning Systems literature. 
In the out-of-sample analysis, since we restrict our time period, the number of crisis and non-crisis episodes decrease for all definitions. However, by looking at Table 7.1, it is observed that decreasing number of currency crisis episodes do not have an impact on the ratio of the correctly predicted currency crisis episodes. For all definitions, the ratio of correctly predicted crisis episodes is more or less the same compared to the in-sample results. Although the number of non-currency crisis episodes decreases, the ratio of correctly predicted non-currency crisis increases because of the increasing number of correctly called crisis episodes.

In the context of Type 1 and Type 2 Errors at $50 \%$ probability threshold value, while Type 1 Error reveals similar results with the in-sample analysis, Type 2 Error shows slightly different results. The reason for Type 1 Error does not vary is, while the total number of currency crisis episodes decreases, the ratio of correctly predicted crisis episodes remains more or less the same. Thus, Type 1 Error ends up with no or little change.

However, the situation is different in the context of the Type 2 Error. For instance, while Type 2 Errors changed between $50.2 \%$ and $59.2 \%$ in the in-sample analysis of the depreciation rate based definition group, according to the out-ofsample results, it varies between $36.7 \%$ and $53 \%$. For the EMP based definition group with varying variables, Type 2 Error was between $49.4 \%$ and $63.3 \%$ in insample analysis but now it varies in lower range; $30.1 \%$ to $55.7 \%$ in the out-ofsample. Moreover, the same finding is also valid for the EMP based definition group with varying standard deviation multiplier. While Type 2 Errors in the in-sample results of this group was between $45.4 \%$ and $49.7 \%$, in the out-of- sample, it varies between $35.3 \%$ and $29.1 \%$. The reason for this decline is as follows: While the total number of non-currency crisis episodes decreases, the number of correctly predicted 
crisis episodes increases with increasing the ratio of the correctly predicted currency crisis episodes. As a result, the number of false alarms decreases and causes a decrease in the Type 2 Error of the EWS models.

When the prediction powers of the definitions are considered, it is seen that all definitions reveal more successful results in the out-of-sample analysis compared to the in-sample results. In the in-sample analysis of the depreciation rate based definition group, the prediction powers was between $41.1 \%$ and $50.8 \%$ while this is $45.6 \%$ and 63.3 in the out-of-sample analysis. For the EMP based definition group with varying variables, the prediction powers vary between $44.4 \%$ and $67.9 \%$ according to the out-of-sample results but it was between $39.7 \%$ and $44.7 \%$ in the insample analysis. Similarly, in the EMP based definition group with varying standard deviation multiplier, while the prediction powers of the definitions varied between $50.4 \%-55 \%$, in the in-sample analysis, the range increases to $63.2 \%-70.8 \%$ in the out-of-sample analysis.

Although we explain the out-of-sample results of the model under different crisis definitions at 50\% threshold level in above paragraphs, we still need to conduct out-of-sample forecasts for different levels of probability thresholds.

\subsection{Alternative Probability Thresholds}

In Table 7.2 we present the prediction powers of the model under different crisis definitions and probability threshold levels for out-of-sample period. 
Table 7.2: Out-of-Sample Results of the Model according to different Currency Crisis Definitions and Probability Threshold Values

\begin{tabular}{|c|c|c|c|c|c|c|c|c|c|c|c|}
\hline & $\begin{array}{c}\text { Probability } \\
\text { Threshold } \\
1 \%\end{array}$ & $\begin{array}{c}\text { Probability } \\
\text { Threshold } \\
2.5 \%\end{array}$ & $\begin{array}{c}\text { Probability } \\
\text { Threshold } \\
5 \%\end{array}$ & $\begin{array}{c}\text { Probability } \\
\text { Threshold } \\
10 \%\end{array}$ & $\begin{array}{c}\text { Probability } \\
\text { Threshold } \\
25 \% \\
\end{array}$ & $\begin{array}{c}\text { Probability } \\
\text { Threshold } \\
50 \%\end{array}$ & $\begin{array}{c}\text { Probability } \\
\text { Threshold } \\
75 \% \\
\end{array}$ & $\begin{array}{c}\text { Probability } \\
\text { Threshold } \\
80 \% \\
\end{array}$ & $\begin{array}{c}\text { Probability } \\
\text { Threshold } \\
85 \%\end{array}$ & $\begin{array}{c}\text { Probability } \\
\text { Threshold } \\
90 \%\end{array}$ & $\begin{array}{c}\text { Probability } \\
\text { Threshold } \\
\mathbf{9 5 \%}\end{array}$ \\
\hline Def 1 & $21.60 \%$ & $23 \%$ & $33.20 \%$ & $41.20 \%$ & $48.20 \%$ & $63.30 \%$ & $63.30 \%$ & $63.30 \%$ & $63.30 \%$ & $63.30 \%$ & $63.30 \%$ \\
\hline Def 2 & $34.00 \%$ & $38 \%$ & $42 \%$ & $43.90 \%$ & $46.90 \%$ & $62.10 \%$ & $62.10 \%$ & $62.10 \%$ & $62.10 \%$ & $62.10 \%$ & $62.10 \%$ \\
\hline Def 3 & $38.40 \%$ & $40 \%$ & $44 \%$ & $43.50 \%$ & $46.60 \%$ & $61.0 \%$ & $61.0 \%$ & $61.0 \%$ & $61.0 \%$ & $61.0 \%$ & $61.0 \%$ \\
\hline Def 4 & $36.00 \%$ & $37.30 \%$ & $38.80 \%$ & $39.30 \%$ & $41.00 \%$ & $47.40 \%$ & $47.40 \%$ & $47.40 \%$ & $47.40 \%$ & $47.40 \%$ & $47.40 \%$ \\
\hline Def 5 & $27.60 \%$ & $29 \%$ & $32.20 \%$ & $41.00 \%$ & $48.60 \%$ & $58.20 \%$ & $58.20 \%$ & $58.20 \%$ & $58.20 \%$ & $58.20 \%$ & $58.20 \%$ \\
\hline Def 6 & $24.10 \%$ & $26 \%$ & $32.80 \%$ & $40.90 \%$ & $43.00 \%$ & $51.50 \%$ & $51.50 \%$ & $51.50 \%$ & $51.50 \%$ & $51.50 \%$ & $51.50 \%$ \\
\hline Def 7 & $23.80 \%$ & $26 \%$ & $32.50 \%$ & $39.20 \%$ & $45.00 \%$ & $48.90 \%$ & $48.90 \%$ & $48.90 \%$ & $48.90 \%$ & $48.90 \%$ & $48.90 \%$ \\
\hline Def 8 & $19.60 \%$ & $21 \%$ & $30.40 \%$ & $38.00 \%$ & $43.00 \%$ & $45.6 \%$ & $45.6 \%$ & $45.6 \%$ & $45.6 \%$ & $45.6 \%$ & $45.6 \%$ \\
\hline Def 9 & $18.10 \%$ & $31.10 \%$ & $38.70 \%$ & $55.50 \%$ & $61.90 \%$ & $64.0 \%$ & $60.1 \%$ & $60.1 \%$ & $60.1 \%$ & $60.1 \%$ & $60.1 \%$ \\
\hline Def 10 & $21.60 \%$ & $29.40 \%$ & $36.90 \%$ & $52.60 \%$ & $59.30 \%$ & $67.9 \%$ & $67.9 \%$ & $67.9 \%$ & $67.9 \%$ & $67.9 \%$ & $67.9 \%$ \\
\hline Def 11 & $25.30 \%$ & $27.80 \%$ & $36.30 \%$ & $50.90 \%$ & $57.70 \%$ & $65.20 \%$ & $65.20 \%$ & $65.20 \%$ & $65.20 \%$ & $65.20 \%$ & $65.20 \%$ \\
\hline Def 12 & $36.40 \%$ & $37.70 \%$ & $41.70 \%$ & $47.10 \%$ & $49.70 \%$ & $44.40 \%$ & $44.40 \%$ & $44.40 \%$ & $44.40 \%$ & $44.40 \%$ & $44.40 \%$ \\
\hline Def 13 & $19.30 \%$ & $25.40 \%$ & $31.80 \%$ & $48.30 \%$ & $50.20 \%$ & $69.40 \%$ & $65.80 \%$ & $65.80 \%$ & $65.80 \%$ & $65.80 \%$ & $65.80 \%$ \\
\hline Def 14 & $25 \%$ & $40.10 \%$ & $48.60 \%$ & $56.10 \%$ & $60.10 \%$ & $63.20 \%$ & $63.20 \%$ & $63.20 \%$ & $63.20 \%$ & $63.20 \%$ & $63.20 \%$ \\
\hline Def 15 & $32 \%$ & $45.70 \%$ & $48.30 \%$ & $55.80 \%$ & $62.60 \%$ & $65.10 \%$ & $65.10 \%$ & $65.10 \%$ & $65.10 \%$ & $65.10 \%$ & $65.10 \%$ \\
\hline Def 16 & $36 \%$ & $46.60 \%$ & $48.60 \%$ & $56.00 \%$ & $62.10 \%$ & $68.20 \%$ & $68.20 \%$ & $68.20 \%$ & $68.20 \%$ & $68.20 \%$ & $68.20 \%$ \\
\hline Def 17 & $35 \%$ & $45.40 \%$ & $48.30 \%$ & $55.60 \%$ & $64.30 \%$ & $68.80 \%$ & $68.80 \%$ & $68.80 \%$ & $68.80 \%$ & $68.80 \%$ & $68.80 \%$ \\
\hline Def 18 & $32 \%$ & $45.10 \%$ & $48.30 \%$ & $54.40 \%$ & $62.00 \%$ & $69.0 \%$ & $69.0 \%$ & $69.0 \%$ & $69.0 \%$ & $69.0 \%$ & $69.0 \%$ \\
\hline Def 19 & $35 \%$ & $44.20 \%$ & $47.90 \%$ & $54.10 \%$ & $65.70 \%$ & $70.20 \%$ & $70.20 \%$ & $70.20 \%$ & $70.20 \%$ & $70.20 \%$ & $70.20 \%$ \\
\hline Def 20 & $35 \%$ & $44.00 \%$ & $47.90 \%$ & $56.80 \%$ & $64.40 \%$ & $70.8 \%$ & $70.8 \%$ & $70.8 \%$ & $70.8 \%$ & $70.8 \%$ & $70.8 \%$ \\
\hline
\end{tabular}

When all of the three definition groups are taken into consideration, as it is found in in-sample analysis, the prediction powers of the models are lowest at the $1 \%$ probability threshold, and as probability threshold increases, the prediction power increases too. One of the key findings in the in-sample analysis was that this increase continues until the $50 \%$ threshold level is reached. In the out-of-sample analysis, it is seen that this finding is still valid. For levels above 50\% threshold (75\%, 80\%, 85\%, $90 \%$ and $95 \%$ ), no changes in prediction power take effect. The below figure shows the relationships between the average prediction powers and the probability threshold values for each definition groups. 


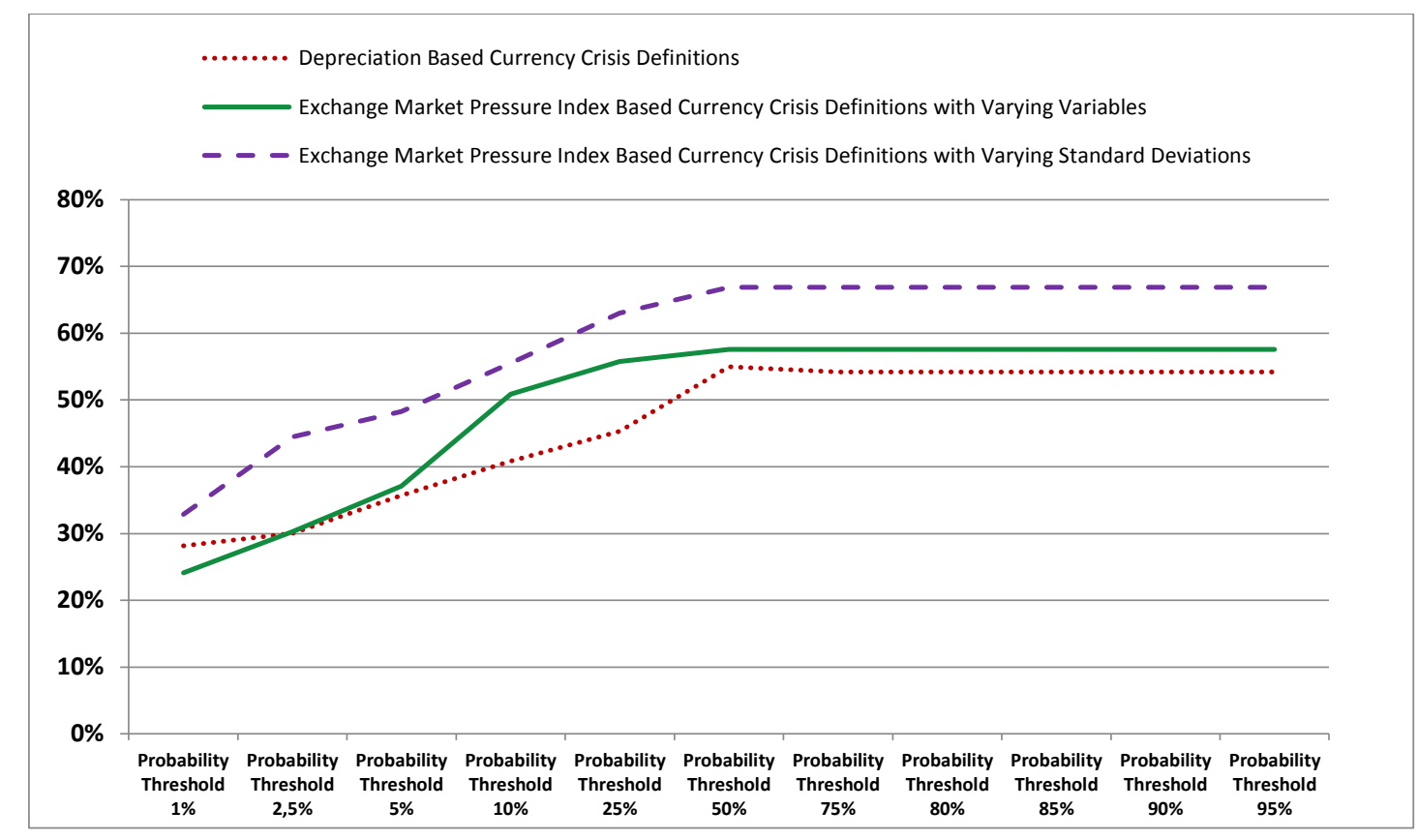

\section{Figure 7.1: Out-of-Sample Results for Prediction Powers according to the Definition Groups}

Unexpectedly, in the out-of-sample analysis, the prediction powers of all models are found remarkably higher compared to in-sample analysis. For instance, for depreciation based Definition, at $1 \%$ probability threshold, the average of the prediction powers of the definitions (Definition 1 to Definition 8) was found 17\% in in-sample analysis. However, in the out-of-sample analysis, this ratio increases to 28\%. The same is applied to EMP index based currency crisis definitions with varying variables and EMP index based currency crisis definitions with varying standard deviation multiplier as well. For the EMP index based currency crisis definitions with varying standard deviation multiplier, the average prediction power of the definitions (Definition 8 to Definition 14) in the out-of-sample analysis at $1 \%$ probability threshold is found $33 \%$ which was $28 \%$ in in-sample analysis. Finally, for the EMP index based currency crisis definitions with varying variables, average prediction power of the definitions (Definition 14 to Definition 20) increases from $16 \%$ to $24 \%$ at the same probability threshold. 
At $50 \%$ threshold, the definitions yield their best prediction powers. At that level probability threshold, the average prediction power of depreciation rate based definition group is found $54 \%$ while this ratio was $46 \%$ in in-sample analysis. The average prediction power of EMP index based currency crisis definitions with varying standard deviation multiplier is $63 \%$ for out-of-sample analysis while insample analysis gave $51 \%$ prediction power. In EMP index based currency crisis definitions with varying variables, this ratio was $47 \%$ according to in-sample analysis and is $68 \%$ in the out-of-sample analysis.

It is essential to investigate what causes this increase. We see that in out-ofsample period, the total number of currency crisis episodes is lower compared to insample period. The models are more successful to capture the non-crisis episodes. Therefore, as the ratio of non-currency crisis episodes to crisis episodes increase (due to decreased number of crisis periods) while the success rates of correct calls more or less the same for both crisis and non-crisis periods, it seems the prediction powers of the models are higher compared to in-sample analysis.

The best and the worst models according to the prediction powers is the same with in-sample analysis. In deprecation rate based definition group, the most successful definition according to out-of-sample results is Def 1 with $63 \%$ prediction power and the worst one is Definition 8 with $45 \%$ prediction power. In the out-ofsample analysis of EMP index based currency crisis definitions with varying variables, the best model is found as the model that is constructed with Def 10 with a prediction power of $68 \%$. On the other hand, even if the prediction power of the model that is constructed with Def 12 increases to $44 \%$ in the out-of-sample analysis (38\% in in-sample analysis), it is still the worst one among all 20 definitions. Lastly, as for in-sample analysis, among the EMP index based currency crisis definitions 
with varying standard deviation multiplier, Def 14 has the worst prediction power in this group with relatively high rate compared to the definitions that belong to other groups $(65 \%)$. In this group, the model that is constructed with Def 20 has the highest prediction power, $71 \%$, which is at the same time the most successful one among all 20 definitions.

The out-of-sample analysis for the prediction powers is conducted for the time period of 1995-2010. Consequently, it is observed that the results between in sample and out sample differ from each other. According to average results of all three definition groups it is possible to conclude that out-of-sample analysis gives higher prediction power results compared to in-sample analysis due to increase in the ratio of correctly predicted crisis and non-currency crisis episodes. However, although the forecast results are different, the prediction power ranking of the models among and within definition groups does not change. 


\section{CHAPTER 8}

\section{CONCLUSION}

This thesis examines the impacts of currency crisis definition differences and probability threshold choices on prediction power of an Early Warning System. These two points are essential as while the first step of constructing an Early Warning System is defining a currency crisis which constitutes the dependent variable of the model, the prediction power of an Early Warning System is directly related with the chosen threshold values.

In the literature, there is a variety of currency crisis definitions. However, it is possible to group these definitions under two main groups as depreciation rate based definitions and Exchange Market Pressure index based definitions. In this thesis, in order to determine the best explanatory variable set for both definition groups, we choose two prominent currency crisis definitions from the literature and investigated the empirical results. For this purpose, for depreciation rate based definitions Reinhart and Rogoff's (2009) and for Exchange Market Pressure index based definitions Eichengreen et al.'s (1996) studies are used.

In the first step of our analysis, we used the same set of explanatory variables, econometric method (logistic regression), country set and time period (1970-2010) for both crisis definitions to be able to identify the impacts of crisis definitions on the 
significances of crisis indicators. The results have shown that, different definition methods identify different sets of variables as crisis indicators. While the GDP per capita, inflation, the ratio of M2 to international reserves, real effective exchange rate and domestic credit provided by banking sector (\% of GDP) were significant in at least one of the regressions for the depreciation-based currency crisis definition; GDP per capita, inflation rate, the ratio of M2 to international reserves, real effective exchange rate and total reserves (\% of total external debt) were significant in at least one of the regressions for the EMP index based currency crisis definition.

After constructing the best explanatory variable set for both definition groups, in order to analyze the impacts of alternative versions of crisis definitions on prediction power of Early Warning Systems, in the second step of our thesis, we extended our currency crisis definitions by including 20 alternative crisis indicators. To be able to see the impacts of the definitions, we conducted the estimations and forecasts with the same set of explanatory variables and econometric method. Furthermore, to be able to see the probability threshold choice effect, we repeated our analysis for each definition 11 times at different threshold levels. Our results have clearly shown that crisis definitions and threshold choices significantly affect the prediction powers of the EWS models. We concluded that the EMP index based definition is a better predictor compared to depreciation based definition according to our results. We also found that EMP index gives better results with higher standard deviation multiplier. One of the important results of this thesis was that all tested currency crisis definitions gave their best results at the $50 \%$ threshold level. Therefore, this led us to conclude that the optimal threshold level for EWS models is $50 \%$. 
In this thesis, we also conducted a robustness test by including some crucial current account variables according to the literature (even if they revealed insignificant results in the first step of our analysis) in order to examine whether they change our prediction power results or not. As a consequence, we saw that adding current account and balance of payment variables do not positively contribute to the prediction power of the Early Warning Systems.

In the final chapter of our thesis, we conducted the out-of-sample analysis by restricting our estimation sample to 1970-1994 and forecast sample to 1995-2010. We conducted estimations and forecasts with the same set of explanatory variables, econometric method and country set for 20 alternative crisis definitions that were used as the dependent variables. As a consequence, we observed that according to average results of all three definition groups, the out-of-sample analysis gives remarkably higher prediction power results compared to in-sample analysis due to increasing ratio of correctly predicted currency crisis and non-currency crisis episodes. However, although the forecast results significantly varies, the prediction power ranking of the models among and within definition groups did not change.

As a result in this thesis we analyzed the Early Warning Systems more fundamentally from the first step of its construction procedure. According to this, to be able to show that two prominent definition groups from the literature identify different variables as crisis indicators, we used Reinhart and Rogoff (2009) and Eichengreen et al.'s (1996) definitions and identified the significant explanatory variables. As we presumed, each definitions identified different explanatory variable sets as the indicators of currency crisis. Following that step, by leaning on the fact that today there are various versions of those prominent studies in the literature, we wanted to see whether those alternative versions do change the prediction ability of 
the EWS models. For this purpose, we identified 20 different versions of Reinhart and Rogoff (2009) and Eichengreen et al.'s (1996) definitions from the literature and test the prediction powers of the models that we constructed with the explanatory variables that we identified as significant in the previous step. Our results confirmed that different definitions give significantly different prediction powers. Furthermore, we had the chance to identify the best definition method. We also wanted to investigate the impacts of the threshold choices on the prediction powers of the EWS models. For this purpose, we identified 11 different threshold levels, and conducted our forecast analysis for 20 currency crisis definitions at each of these levels. Our results have shown that $50 \%$ threshold is the optimal one as until that level the prediction powers of the models significantly increase but keep constant above it. Following those main analyses as we briefly summarized above we conducted our robustness tests and out-of-sample analyses. Therefore, we did not design an Early Warning System model that gave the highest possible prediction power. Instead, we empirically showed the impacts of crisis definitions and threshold choices on the success rates of the models and crisis indicators. 


\section{BIBLIOGRAPHY}

Babecký, Jan and et al. 2012. "Banking, Debt, and Currency Crises: Early Warning Indicators for Developed Countries," ECB Working Paper No:1485.

Baltagi, Badi. 2005. Econometric Analysis of Panel Data. New York: John Wiley \& Sons.

Bauer, Christian, Bernhard Herz and Volker Karb. 2005. "The Other Twins: Currency and Debt Crises," Review of Economics, 54(3): 248-267.

Berg, Andrew, and Catherine Pattillo. 1999. "Predicting Currency Crises: The Indicators Approach and an Alternative," Journal of International Money and Finance, 18:4, pp. $561-586$.

Błaszkiewicz, Monika, and Wojciech Paczyński. 2003. "The Economic and Social Consequences of Currency Crises," Chapter 4 in Currency Crises in Emerging Markets, New York: Springer Science + Business Media, 145-168.

Bordo, Michael and et al. 2001. "Is the Crisis Problem Growing More Severe?" Economic Policy 16(32): 1-82.

Borio, Claudio and Mathias Drehmann. 2009. "Assessing the Risk of Banking Crises - Revised," BIS Quarterly Review, pp. 29-46.

Brakman, Steven and et al. 2013. "Currency Crises and Exchange Rate Policy," Chapter 9 in International Economics and Business: Nations and Firms in the Global Economy, Southport: Cambridge University Press, 295-311.

Bussiere, Matthieu, and Marcel Fratzscher. 2002. "Towards a New Early Warning System of Financial Crises," Journal of International Money and Finance, 25(6): 953-973.

Candelon, Bertrand, Christophe Hurlin, and Elena Dumitnescu. 2013. "Currency Crisis Early Warning Systems: Why They should be Dynamic," Ipag Working Paper, No:399.

Caprio, Gerard and Klingebiel, Daniela. 2006. "Bank Insolvencies: Cross Country Experience," World Bank Publications, No:1620. 
Castillo, Fernando. 2011. "Predicting a Currency Crisis Alternative Approaches and Applications to the Philippines," Singapore Management University, No: 1489312.

Cheang, Nicholas. 2008. "Early Warning System for Financial Crises," Macao Monetary Research Bulletin, 11: 61-77.

Claessens, Stijn and Kose, Stijn. 2013. "Financial Crises: Explanations, Types, and Implications," IMF Working Paper, No:13/28.

Comelli, Fabio. 2014. "Comparing the Performance of Logit and Probit Early Warning Systems for Currency Crises in Emerging Market Economies," IMF Working Paper, No. 14/65.

Davis, Philip E. and Karim, Dilruba. 2008. "Comparing Early Warning Systems for Banking Crises,” Journal of Financial Stability, Vol. 4, pp. 89-120.

Edison, Hali. 2000. "Do Indicators of Financial Crises Work? An Evaluation of An Early Warning System,” International Finance Discussion Papers No: 675.

Eichengreen, Barry, Andrew K. Rose, and Charles Wyplosz. 1995. "Exchange Market Mayhem: the Antecedents and Aftermath of Speculative Attacks," Economic Policy 21: 5-42.

Eichengreen, Barry, Andrew K. Rose, and Charles Wyplosz. 1996. "Contagious Currency Crises," NBER Working Paper Series No. 5681.

Esquivel, Gerardo, and Felipe Larraín. 1998. "Explaining Currency Crises,” HIID Development Discussion Paper No. 666.

Flood, Robert P. and Peter M. Garber. 1984. "Collapsing Exchange-Rate Regimes: Some Linear Examples,” Journal of International Economics, 17: 1-13.

Frankel, Jeffrey, and Andrew Rose. 1996. "Currency Crashes in Emerging Markets: An Empirical Treatment," Journal of International Economics 41(3): 351-366.

Frost, Jon, and Ayako Saiki. 2013. "Early Warning for Currency Crises: What is the Role of Financial Openness?" DNB Working Paper No. 373.

Girton, Lance, and Don Roper. 1977. "A Monetary Model of Exchange Market Pressure Applied to the Postwar Canadian Experience," American Economic Review 67(4): 537-548.

Glick, Reuven and Hutchison, Michael. 1999. "Banking and Currency Crises: How Common Are Twins?" Cambridge University Press, 35-69.

Goldfajn, Ilan, and Rodrigo Valdes. 1997. "Are Currency Crisis Predictable?” IMF Working Paper No: 97/159. 
Goldstein, Morris, Graciela Kaminsky, and Carmen Reinhart. 2000. “Assessing Financial Vulnerability: An Early Warning System for Emerging Markets," Washington DC: Institute for International Economics.

Heckman, James. 1981. "Heterogeneity and State Dependence" Chapter 3 in Studies in Labor Markets. Chicago: University of Chicago Press, 91-139.

Ito, Takatoshi, and Keisuke Orii. 2009. "Early Warning Systems of Currency Crises," Policy Research Institute 5(1): 69-80.

Kaminsky, Graciela, Saul Lizondo, and Carmen Reinhart. 1998. "Leading Indicators of Currency Crises,” Policy Research Working Paper No.1852.

Kindleberger, Charles. 2000. Manias, Panics, and Crashes: A History of Financial Crisis. New York: John Wiley \& Sons.

Kindman, Andrew. 2010. "Currency Crisis Early Warning Systems: Robust Adjustments to the Signal Based Approach," Duke University.

Kruger, Mark, Patrick Osakwe, and Jennifer Page. 1998. "Fundamentals, Contagion and Currency Crises: An Empirical Analysis", Bank of Canada Working Paper, No: 98(10).

Krugman, Paul. 1979. “A Model of Balance of Payments Crises," Journal of Money, Credit, and Banking, vol. 11, pp. 311-325.

Kumar, Naveen and Raman Singh. 2013. "Global Financial Crisis: Corporate Governance Failures and Lessons," Journal of Finance, Accounting and Management, 4(1): 21-34.

Li, Jie, Rajan Ramkishen and Thomas Willett. 2006. "Measuring Currency Crises Using Exchange Market Pressure Indices: The Imprecision of Precision Weights," Journal of Financial Economic Policy, Vol. 4 Iss: 2, pp. 128-145.

Masson Paul. 2006. "Contagion: Monsoonal effects, Spillovers, and Jumps between Multiple Equilibria," IMF Working Paper, No. 98/142.

Meese, Richard and Rose, Andrew. 1996. "Exchange Rate Instability: Determinants and Predictability,"Review of Economic Studies, 58, pp. 103-166.

Mendoza, Enrique, Vincenzo Quadrini and Jose-Victor Rios-Rull. 2007. "Financial Integration, Financial Deepness and Global Imbalances," National Bureau of Economic Research, No. 12909.

Milessi-Ferretti, Maria, and Assaf Razin. 1998. "Current Account Reversals and Currency Crises: Empirical Regularities,” NBER Working Paper, No. 6620.

Paltonen, Tuomas. 2006. "Are Emerging Market Currency Crises Predictable? A Test," Europen Central Bank Working Paper Series, No:571. 
Percic, Stanislav, Marius Apostoaie, and Vasile Cocris. 2013. "Early Warning Systems for Financial Crises. A Critical Approach," CES Working Papers, 5(1): 77-88.

Pesenti, Paolo and Tille, Cedric. 2000. "The Economics of Currency Crisis and Contagion: An Introduction," Economic Policy Review, pp.3-16.

Pontines, Victor and Reza Siregar. 2004. "Fundamental Pitfalls of Exchange Market Pressure-Based Approaches to Identification of Currency Crises," International Review of Economics and Finance 17(3): 345-365.

Reed, Howard. 1996. "Restructuring the International Financial System," The Brown Journal of World Affairs, 2(2). Pp 263-273.

Reinhart, Carmen, Morris Goldstein and Graciela Kaminsky. 2000. "Assessing financial vulnerability, an early warning system for emerging markets: Introduction," MPRA Paper, No. 13629.

Reinhart, Carmen and Rogoff, Kenneth. 2009. "This Time is Different:A Panoramic View of Eight Centuries of Financial Crises," NBER Working Paper Series, No. 13882.

Rydqvist, Johan. 2005. "FDI and Currency Crises: Currency crises and the inflow of FDI," Pacific-Basin Finance Journal, 2, pp.165-199.

Sachs, Jeffrey, Aaron Tornell and Andres Velasco. 1996. "Financial Crises in Emerging Markets: The Lessons from 1995," Brookings Papers on Economic Activity, 27(1), pp.147-216.

Vlaar, Peter. 1999. "Currency Crisis Models for Emerging Markets," De Nederlandsche Bank Econometric Research and Special Studies Department, No.45. 


\section{APPENDICES}

\section{A.1. DEFINITIONS OF EXPLANATORY VARIABLES}

Definitions are directly taken from World Bank, World Development Indicators Data. Some of the indicators are calculated and grouped according to Kamisky, Reinhart and Rogoff (1998) variable categorization.

\section{Capital Account Variables}

\section{Foreign Direct Investments, Net}

Foreign direct investment are the net inflows of investment to acquire a lasting management interest (10 percent or more of voting stock) in an enterprise operating in an economy other than that of the investor. It is the sum of equity capital, reinvestment of earnings, other long-term capital, and short-term capital as shown in the balance of payments. This series shows total net, that is, net FDI in the reporting economy from foreign sources less net FDI by the reporting economy to the rest of the world. Data are in current U.S. dollars.

\section{The Ratio of Foreign Direct Investment to GDP}

Foreign direct investment are the net inflows of investment to acquire a lasting management interest (10 percent or more of voting stock) in an enterprise operating in an economy other than that of the investor. It is the sum of equity capital, reinvestment of earnings, other long-term capital, and short-term capital as shown in the balance of payments. This series shows net inflows (new investment inflows less disinvestment) in the reporting economy from foreign investors, and is divided by GDP. 


\section{Portfolio equity, net inflows (BoP, current US\$)}

Portfolio equity includes net inflows from equity securities other than those recorded as direct investment and including shares, stocks, depository receipts (American or global), and direct purchases of shares in local stock markets by foreign investors. Data are in current U.S. dollars.

\section{Debt Profile Variables}

\section{Short-term Debt (\% of Total Reserves)}

Short-term debt includes all debt having an original maturity of one year or less and interest in arrears on long-term debt. Total reserves includes gold.

\section{Public and publicly guaranteed debt service (\% of GNI)}

Public and publicly guaranteed debt service is the sum of principal repayments and interest actually paid in currency, goods, or services on long-term obligations of public debtors and long-term private obligations guaranteed by a public entity.

\section{Multilateral Debt Service (\% of Public and Publicly Guaranteed Debt Service)}

Multilateral debt service is the repayment of principal and interest to the World Bank, regional development banks, and other multilateral agencies. public and publicly guaranteed debt service is the sum of principal repayments and interest actually paid in currency, goods, or services on long-term obligations of public debtors and long-term private obligations guaranteed by a public entity.

\section{Interest payments on external debt (\% of GNI)}

Total interest payments to gross national income.

\section{External debt stocks (\% of GNI)}

Total external debt stocks to gross national income. Total external debt is debt owed to nonresidents repayable in currency, goods, or services. Total external debt is the sum of public, publicly guaranteed, and private nonguaranteed long-term debt, use of 
IMF credit, and short-term debt. Short-term debt includes all debt having an original maturity of one year or less and interest in arrears on long-term debt. GNI (formerly GNP) is the sum of value added by all resident producers plus any product taxes (less subsidies) not included in the valuation of output plus net receipts of primary income (compensation of employees and property income) from abroad.

\section{Domestic credit to private sector by banks (\% of GDP)}

Domestic credit to private sector by banks refers to financial resources provided to the private sector by other depository corporations (deposit taking corporations except central banks), such as through loans, purchases of nonequity securities, and trade credits and other accounts receivable, that establish a claim for repayment. For some countries these claims include credit to public enterprises.

\section{Domestic credit to private sector (\% of GDP)}

Domestic credit to private sector refers to financial resources provided to the private sector by financial corporations, such as through loans, purchases of nonequity securities, and trade credits and other accounts receivable, that establish a claim for repayment. For some countries these claims include credit to public enterprises. The financial corporations include monetary authorities and deposit money banks, as well as other financial corporations where data are available (including corporations that do not accept transferable deposits but do incur such liabilities as time and savings deposits). Examples of other financial corporations are finance and leasing companies, money lenders, insurance corporations, pension funds, and foreign exchange companies.

\section{Total reserves (\% of total external debt)}

International reserves to total external debt stocks.

\section{Short-term debt (\% of total reserves)}

Short-term debt includes all debt having an original maturity of one year or less and interest in arrears on long-term debt. Total reserves includes gold.

\section{External debt stocks, private nonguaranteed (PNG) (DOD, current US\$)}

Private nonguaranteed external debt comprises long-term external obligations of private debtors that are not guaranteed for repayment by a public entity. Data are in current U.S. dollars. 
Debt service on external debt, public and publicly guaranteed (PPG) (TDS, current US\$)

Public and publicly guaranteed debt service is the sum of principal repayments and interest actually paid in currency, goods, or services on long-term obligations of public debtors and long-term private obligations guaranteed by a public entity. Data are in current U.S. dollars.

\section{Current Account Variables}

\section{Real effective exchange rate}

Real effective exchange rate is the nominal effective exchange rate (a measure of the value of a currency against a weighted average of several foreign currencies) divided by a price deflator or index of costs.

\section{Current account balance (\% of GDP)}

Current account balance is the sum of net exports of goods and services, net primary income, and net secondary income.

\section{Exports of goods and services (annual \% growth)}

Annual growth rate of exports of goods and services based on constant local currency. Aggregates are based on constant 2005 U.S. dollars. Exports of goods and services represent the value of all goods and other market services provided to the rest of the world. They include the value of merchandise, freight, insurance, transport, travel, royalties, license fees, and other services, such as communication, construction, financial, information, business, personal, and government services. They exclude compensation of employees and investment income (formerly called factor services) and transfer payments.

\section{Imports of goods and services (annual \% growth)}

Annual growth rate of imports of goods and services based on constant local currency. Aggregates are based on constant 2005 U.S. dollars. Imports of goods and 
services represent the value of all goods and other market services received from the rest of the world. They include the value of merchandise, freight, insurance, transport, travel, royalties, license fees, and other services, such as communication, construction, financial, information, business, personal, and government services. They exclude compensation of employees and investment income (formerly called factor services) and transfer payments.

\section{International Variables}

\section{Use of IMF credit (DOD, current US\$)}

Use of IMF credit denotes members' drawings on the IMF other than amounts drawn against the country's reserve tranche position. Use of IMF credit includes purchases and drawings under Stand-By, Extended, Structural Adjustment, Enhanced Structural Adjustment, and Systemic Transformation Facility Arrangements as well as Trust Fund loans. SDR allocations are also included in this category.

\section{Financial Liberalization Variables}

\section{Risk premium on lending (lending rate minus treasury bill rate, \%)}

Risk premium on lending is the interest rate charged by banks on loans to private sector customers minus the "risk free" treasury bill interest rate at which short-term government securities are issued or traded in the market. In some countries this spread may be negative, indicating that the market considers its best corporate clients to be lower risk than the government. The terms and conditions attached to lending rates differ by country, however, limiting their comparability.

\section{Deposit interest rate (\%)}

Deposit interest rate is the rate paid by commercial or similar banks for demand, time, or savings deposits. The terms and conditions attached to these rates differ by country, however, limiting their comparability. 
Real interest rate is the lending interest rate adjusted for inflation as measured by the GDP deflator.

\section{Other Financial Variables}

\section{Money and quasi money (M2) as \% of GDP}

Money and quasi money comprise the sum of currency outside banks, demand deposits other than those of the central government, and the time, savings, and foreign currency deposits of resident sectors other than the central government.

\section{Money and quasi money (M2) to total reserves ratio}

Money and quasi money comprise the sum of currency outside banks, demand deposits other than those of the central government, and the time, savings, and foreign currency deposits of resident sectors other than the central government.

\section{Real Sector Variables}

\section{Inflation, consumer prices (annual \%)}

Inflation as measured by the consumer price index reflects the annual percentage change in the cost to the average consumer of acquiring a basket of goods and services that may be fixed or changed at specified intervals, such as yearly. The Laspeyres formula is generally used.

\section{GDP per capita growth (annual \%)}

Annual percentage growth rate of GDP per capita based on constant local currency. Aggregates are based on constant 2005 U.S. dollars. GDP per capita is gross domestic product divided by midyear population. GDP at purchaser's prices is the sum of gross value added by all resident producers in the economy plus any product taxes and minus any subsidies not included in the value of the products. It is 
calculated without making deductions for depreciation of fabricated assets or for depletion and degradation of natural resources.

\section{Unemployment, total (\% of total labor force) (modeled ILO estimate)}

Unemployment refers to the share of the labor force that is without work but available for and seeking employment.

\section{Gross savings (\% of GDP)}

Gross savings are calculated as gross national income less total consumption, plus net transfers.

\section{Net National Savings ( $\%$ of GNI)}

Net national savings are equal to gross national savings less the value of consumption of fixed capital. 


\section{A2. CURRENCY CRISIS DEFINITIONS IN SELECTED LITERATURE}

Table A2.1: Currency Crisis Definitions in Selected Literature

Currency Crisis Definition

Eichengreen, Rose, and Wyplosz (1994) Their exchange market pressure is based on change in Eichengreen, Rose, and Wyplosz (1994)

and the change in interest rate.

and index exceeds its mean by 1.5

They define currency crisis as a percent or greater, which is at least 10 percent greater than the depreciation in the preceding
Time Period

Country Set

Explanatory Variables

Econometric Method

Total non-gold internationa reserves, period-average exchange rates, short-term interest rates (money market rates (where possible, discount rate (both measured in dollars, the current account (converted to domestic currency), the central government budget position, both une foreign exchange reserves to monthly imports, the ratio of the current account to GDP, and the real exchange rate (which measures competitiveness) as vulnerability to external shocks, foreign Direct Investment (FDI) vs. portfolio flows, long-term vs. measured as percentages of nominal GDP, long-term government bond yields, nominal stock market index domestic credit, M1, M2, CPI, real GDP, real effective exchange business sector , rage governmental electoral victories and defeats The rate of growth of domestic policy), the government budget as a fraction of GDP (a crude measure of fiscal policy), the ratio of reserves to imports, the current account as a percentage of GDP the growth rate of real output, and the degree of over-valuation, the ratio of debt to GNP, the ratio of

Probit mode 
short-term portfolio capital, fixedrate vs. floating- rate borrowing,

and domestic-currency vs.

short-term northern interest rates

and real output growth.

They construct a crisis index as a weighted avarage of the

Sachs, Tornell, Velasco (1996) devaluation rate with respect to US dollar and percentage chan
in foreign exchange reserves

1989-1994

Crisis are identified by EMP index. This index is weighted avarage of monthly percentage (units of domestic currency per 作 depending on which is relevant) and the negative of monthly percentage changes in gross international reserves (in dollars). Periods where index is above its deviations are defined as crisis.
1970-1995 15 Developing, 5 Developed Countries
Real exchange rate depreciation, lending boom, M2 over reserves, crisis index, current account, investment and savings, government consumption, capital
inflows, short-term capital inflows

$\begin{array}{ll}20 \text { Emerging Countries } & \begin{array}{l}\text { investment } \\ \text { government consumption, capital } \\ \text { inflows, short-term capital inflows }\end{array}\end{array}$

International reserves, imports, exports, terms of trade, deviations of the real Exchange rate from trend, the differential between foreign and domestic real interes rates on depits, excess real MI the ratio of Money multiplier, GDP, the real interest rate deposits, the ratio of lending to deposits, the ratio of lending to
deposit interest rates, stock of commercial banks deposits, the ratio of broad Money to gross international reserves, an index of output, an index of equity prices

(o GDP the ratio of $\mathrm{M} 2$ to reserves, the ratio of current account deficit (surplus) to GDP, the ratio of government budget deficit They define EMP as a weighted avarage of percentage changes in
the nominal exchange rate and

Kruger, Osakwe, Page (1998) negative of percentage changes in international reserves. They

1977-1993

19 developing countries (surplus) to GDP, the growth rate rate of per capita GDP, the ratio of banks' claims on the private sector to GDP, the CPI inflation rate, the real exchange rate, foreign interest rate variable.
Probit model standard
Probit model
Signal approach 
They consider that currency crisis exists when there is an abrupt rate. First, they say there exist a currency crisis if the accumulated three month real exchange rate changes is 15 percent or more. Second, they say there is a Larrain, Esquivel (1998) currency crisis if one month in
the real exchange rate is higher than 2.54 times the country specific standard deviation of the real exchange rate monthly growth rate, provided that it also

Milesi-Ferretti and Razin (1998) use a definition that requires, in addition to 25 percent depreciation, at least a doubling in the rate of depreciation with respect to the previous year and a rate of depreciation the previous year below 40 percent. To restrict the sample to episodes in which

Milesi-Ferretti, Razin (1998) the exche definition

they employ requires a 15 percent minimum rate of depreciation, a minimum 10 percent increase in the rate of depreciation with respect to the previous year, and a rate of depreciation of below 10 percentage points in the previous

year.
1975-1996

30 countries
Seignorage, Real Exchange Rate Misalignment, Current Accor Balance, M2/Reserves, Terms of Trade, Per Capita Income Growth, Contagion Effects.
Probit model
Macroeconomics: GDP growth, real consumption, fiscal balance, level of GDP per capita account belone, the real effective exchange rate, the dearee of real exchange tate overvaluation, the degree of openness to trade, the level of external official transfers as a fraction of GDP Debt: The ratio of external debt to output, the interest burden of deb as a fraction of GDP, the share of concessional debt, short term debt, public debt and multilatera debt in total debt and the ratio of foreign direct inflows to debt outstanding.

ThP, the ratio of M2 to the ratio of private Foreign: The real interest rote in the United States, the rate of growth in OECD countries and the terms of trade.
Multivariate Probit model

Countries
concessional debt, shblic debt and multilateral
debt in total debt and the ratio of
foreign direct inflows to
debt outstanding.
Financial: the ratio of M2 to
GDP, the credit growth rate and
the ratio of private credit to GDP
Foreign: The real interest rate in
the United States, the rate of
growth in OECD countries and
the terms of trade.

They use the indicators of KLR, STV and Frankel, Rose
Signal Approach and Probit Model
Berg, Pattillo (1998) 
They construct FEMP index as a weighted average of monthly exchange rate changes and reserve

Aziz, Caramazza, Salgado (2000) his threshold which is 1,5 times the pooled standard deviation of the calculated index plus the pooled mean of the index.
Real effective exchange rate, export growth, trade balance,

M1 Growth, nominal M2 Growth, nominal domestic credit growth, real M1 growth, real M2 growth, real domestic credit growth, real interest rate, change in real stock prices, change in foreign reserves, $\mathrm{M} 2 /$ Reserves, change in M2/M1, output growth, world real interes rate, change in the unemployment rate, current account balance, fiscal balance, short term capita
The index is calculated as the weighted average of percent changes in the bilateral nominal Edison (2000) change in foreign reserves. If this tex exi crisis occurs.
Current account indicators: deviations of the real exchange rate from the trend, the value of imports, and the value of exports. Capital account indicators: foreign exchange reserves, the ratio of M2 to foreign exchange reserves, and the domestic foreign real interest rate differential on deposits. Real sector indicators. industrial prices.

Financial indicators: M2 multiplier, the ratio of domestic multiplier, the ratio of domestic
credit to nominal GDP, the real interest rate on deposits, the ratio of lending-to-deposit interest rates, excess real M1 balances, and commercial bank deposits
Probit Model

Signal Approach
External Competitiveness: REER overvaluation, Current account Terms of trade, Export and import growth EMP is a weighted average of the
change of the real effective exchange rate, the change in the

Bussiere and Fratzscher (2002)
$\begin{aligned} & \text { interest rate and the change in } \\ & \text { foreign exchange reserves. }\end{aligned}$ $\begin{array}{lll}\text { foreign } & \text { exchange reserves. } \\ \text { Currency } & \text { crisis occurs if this }\end{array}$ index is above the mean by 2 1993-2001

32 Countries standard deviations.

debt/reserves, Total Short-term Debt composition, foreign dires, investments, portfolio investment Total net capital inflows, Foreign exchangereserves.

Domestic Real \& public Sector:
Binomial and Multinomial Logit Models 
stance, public debt), Inflation rate,

Domestic investment ratios, Real

estates.

Domestic Financial Sector:

Domestic Credit to private \& government sector, deposit/ M2 (\% GDP, \& res) equity market indices, Bank deposits Global Factors: GDP growth rate in G3, US, EU interest rates, Equity market performance in $\mathrm{G} 3$, Commodity/oilpric

Contagion

An annual depreciation versus US dollar (or the relevant anchor

Reinhart and Rogoff (2009) currency) of $15 \%$ or more

$1800-2006$

Crise behavior of an index called FEMP. This index is the weighted average of

udsayapkorn, Dibooglu, exchange rate and percentage Mather (2010)

international

reserves. A currency crisis is

of exchange market pressure

exceeds the mean by more than 2

standard deviations.
Exchange rate, currency debasement, real GDP in PPP 1990, exports, government
finance, national accounts, current account deficit for finentr. real \& nominal GDP for financial ctr, st \& interest rates for financia ctr, world commodity prices/crashes inflation, currency, debasement, banking crises, external and domestic default, CPI

International reserves (in US dollars), imports (in US dollars), exports (in US dollars), terms of trade, deviations of the real exchange rate from a deterministic time trend (in percentage terms), the real interest foreign depos oxs ace balances, the money multiplier M2, the ratio of domestic credit to GDP, the real interest rate deposits, the ratio of nomina lending to deposit rates, the ratio of broad money to gros international reserves, an index of output, index of equity price (measured in US dollars), the level of M2 reserves, current account/GDP

\section{Multinomial Logit Model}

\section{Multivariate Probit Model} and Signal Approach 
EMP index is comprised of

change in exchange rate, interest

Candelon, Dumitrescu and Hurlin (2010)

rate and foreign reserves.

Currency crisis occurs if this

index is more than 2 standard

deviation plus mean of the index.

1985-2008

e one-year growth rate of international reserves, the one-

one-year growth rate of exports,

the ratio of M2 to foreign

reserves, the one-year growth rate

of M2 to foreign reserves, the

one-year growth rate of M2

multiplier, the one-year growth

rate of domestic credit over GDP.

real interest rate and real 


\section{A3. EMPIRICAL RESULTS OF THE ROBUSTNESS TESTS}

Table A3.1: Regressions with Exports of Goods and Services (Annual \% Growth)

\begin{tabular}{|c|c|c|c|c|c|c|c|c|}
\hline & Def1 & Def2 & Def3 & Def4 & Def5 & Def6 & Def7 & Def8 \\
\hline Export Growth & $\begin{array}{l}-0.000154 \\
(-0.91)\end{array}$ & $\begin{array}{c}-0.000219 \\
(-0.97)\end{array}$ & $\begin{array}{c}-0.000251 \\
(-0.94)\end{array}$ & $\begin{array}{c}-0.000192 \\
(-0.53)\end{array}$ & $\begin{array}{c}-0.000130 \\
(-0.69)\end{array}$ & $\begin{array}{c}-0.000199 \\
(-0.78)\end{array}$ & $\begin{array}{c}-0.000313 \\
(-1.04)\end{array}$ & $\begin{array}{c}-0.000284 \\
(-0.78)\end{array}$ \\
\hline $\begin{array}{l}\text { The ratio of M2 to } \\
\text { International Reserves }\end{array}$ & $\begin{array}{c}-0.00108 * * * \\
(-3.53)\end{array}$ & $\begin{array}{c}-0.00115^{* * * *} \\
(-3.02)\end{array}$ & $\begin{array}{c}-0.000765^{*} \\
(-1.80)\end{array}$ & $\begin{array}{c}-0.00134^{*} \\
(-1.82)\end{array}$ & $\begin{array}{c}-0.000885^{* * * *} \\
(-2.74)\end{array}$ & $\begin{array}{c}-0.000981^{* * *} \\
(-2.43)\end{array}$ & $\begin{array}{c}-0.000568 \\
(-1.21)\end{array}$ & $\begin{array}{c}-0.00146^{* * *} \\
(-1.98)\end{array}$ \\
\hline $\begin{array}{l}\text { Total reserves (\% of } \\
\text { total external debt) }\end{array}$ & $\begin{array}{c}-0.000194 \\
(-0.72)\end{array}$ & $\begin{array}{c}-0.000566 \\
(-1.58)\end{array}$ & $\begin{array}{c}-0.000911 * * \\
(-2.15)\end{array}$ & $\begin{array}{c}-0.00137 * * \\
(-2.07)\end{array}$ & $\begin{array}{c}-0.0000189 \\
(-0.06)\end{array}$ & $\begin{array}{c}-0.000363 \\
(-0.92)\end{array}$ & $\begin{array}{c}-0.000552 \\
(-1.19)\end{array}$ & $\begin{array}{c}-0.00143^{* * *} \\
(-2.16)\end{array}$ \\
\hline GDP per Capita Growth & $\begin{array}{c}-0.000264 * \\
(-1.66)\end{array}$ & $\begin{array}{c}-0.000602 * * * * \\
(-2.80)\end{array}$ & $\begin{array}{c}-0.000697 * * * * \\
(-2.71)\end{array}$ & $\begin{array}{c}-0.000208 \\
(-0.61)\end{array}$ & $\begin{array}{c}-0.000239 \\
(-1.39)\end{array}$ & $\begin{array}{c}-0.000662^{* * * *} \\
(-2.79)\end{array}$ & $\begin{array}{c}-0.000676^{* *} \\
(-2.40)\end{array}$ & $\begin{array}{c}-0.000180 \\
(-0.53)\end{array}$ \\
\hline $\begin{array}{l}\text { Domestic credit } \\
\text { provided by banking } \\
\text { sector }\end{array}$ & $\begin{array}{l}0.000563^{* *} \\
(2.05)\end{array}$ & $\begin{array}{l}0.000779 * * \\
(2.27)\end{array}$ & $\begin{array}{c}0.000306 \\
(0.82)\end{array}$ & $\begin{array}{c}0.00113^{*} \\
(1.78)\end{array}$ & $\begin{array}{c}0.000336 \\
(1.19)\end{array}$ & $\begin{array}{c}0.000487 \\
(1.41)\end{array}$ & $\begin{array}{c}0.000168 \\
(0.44)\end{array}$ & $\begin{array}{c}0.00132^{* *} \\
(1.99)\end{array}$ \\
\hline $\begin{array}{l}\text { Reel effective exchange } \\
\text { rate }\end{array}$ & $\begin{array}{c}0.000338 \\
(0.86)\end{array}$ & $\begin{array}{c}0.000367 \\
(0.66)\end{array}$ & $\begin{array}{c}0.000722 \\
(1.07)\end{array}$ & $\begin{array}{c}0.00157 \\
(1.29)\end{array}$ & $\begin{array}{l}0.0000761 \\
(0.18)\end{array}$ & $\begin{array}{l}0.0000540 \\
(0.09)\end{array}$ & $\begin{array}{c}0.000617 \\
(0.88)\end{array}$ & $\begin{array}{c}0.00181 \\
(1.52)\end{array}$ \\
\hline Inflation Rate & $\begin{array}{c}0.000234 \\
(1.29)\end{array}$ & $\begin{array}{c}0.000241 \\
(1.00)\end{array}$ & $\begin{array}{c}0.000421 \\
(1.47)\end{array}$ & $\begin{array}{c}0.000383 \\
(0.93)\end{array}$ & $\begin{array}{c}0.000216 \\
(1.10)\end{array}$ & $\begin{array}{c}0.000169 \\
(0.63)\end{array}$ & $\begin{array}{c}0.000211 \\
(0.67)\end{array}$ & $\begin{array}{c}0.000287 \\
(0.71)\end{array}$ \\
\hline$N$ & 947 & 582 & 509 & 285 & 946 & 581 & 508 & 285 \\
\hline
\end{tabular}

\begin{tabular}{|c|c|c|c|c|c|}
\hline & Def9 & Def10 & Def11 & Def12 & Def13 \\
\hline \multirow[t]{2}{*}{ Export Growth } & -0.000358 & -0.000139 & -0.000113 & -0.000296 & -0.0000596 \\
\hline & $(-1.61)$ & $(-0.70)$ & $(-0.66)$ & $(-0.43)$ & $(-0.27)$ \\
\hline \multirow{2}{*}{$\begin{array}{l}\text { The ratio of M2 to } \\
\text { International Reserves }\end{array}$} & 0.0000550 & $-0.000697^{*}$ & -0.000302 & 0.000547 & $-0.00133^{* * *}$ \\
\hline & $(0.15)$ & $(-1.84)$ & $(-0.91)$ & $(0.55)$ & $(-2.97)$ \\
\hline \multirow{2}{*}{$\begin{array}{l}\text { Total reserves (\% of total } \\
\text { external debt) }\end{array}$} & 0.000399 & 0.000361 & 0.000404 & -0.0000342 & $0.000635^{*}$ \\
\hline & (1.18) & $(1.10)$ & (1.43) & $(-0.03)$ & (1.76) \\
\hline \multirow[t]{2}{*}{ GDP per Capita Growth } & -0.000282 & 0.000124 & 0.0000154 & -0.000819 & 0.000156 \\
\hline & $(-1.33)$ & $(0.62)$ & $(0.09)$ & $(-1.08)$ & $(0.68)$ \\
\hline \multirow{2}{*}{$\begin{array}{l}\text { Domestic credit provided by } \\
\text { banking sector }\end{array}$} & $0.000647^{*}$ & 0.000435 & -0.000131 & -0.000625 & 0.000433 \\
\hline & (1.84) & (1.35) & $(-0.53)$ & $(-0.85)$ & (1.18) \\
\hline \multirow[t]{2}{*}{ Reel effective exchange rate } & 0.0000390 & -0.0000550 & $-0.000949 *$ & -0.0000367 & 0.000588 \\
\hline & $(0.09)$ & $(-0.11)$ & $(-1.95)$ & $(-0.02)$ & $(1.20)$ \\
\hline \multirow[t]{2}{*}{ Inflation Rate } & -0.000244 & 0.0000618 & $-0.000468 * * *$ & -0.000222 & 0.000123 \\
\hline & $(-1.10)$ & $(0.31)$ & $(-2.61)$ & $(-0.29)$ & $(0.54)$ \\
\hline$N$ & 861 & 751 & 684 & 112 & 713 \\
\hline
\end{tabular}

t statistics in parentheses

$* p<0.1, * * p<0.05, * * * p<0.01$

Estimates are fixed effect panel estimation results

Using a nonparametric bootstrap, Stata provides a heteroscedasticity robust covariance 


\begin{tabular}{|c|c|c|c|c|c|c|c|}
\hline & Def14 & Def15 & Def16 & Def17 & Def18 & Def19 & Def20 \\
\hline Export Growth & $\begin{array}{c}-0.000171 \\
(-0.90)\end{array}$ & $\begin{array}{c}-0.000411 \\
(-1.43)\end{array}$ & $\begin{array}{c}-0.000522 \\
(-1.60)\end{array}$ & $\begin{array}{c}-0.000522 \\
(-1.60)\end{array}$ & $\begin{array}{c}-0.0000507 \\
(-0.22)\end{array}$ & $\begin{array}{c}-0.000120 \\
(-0.51)\end{array}$ & $\begin{array}{c}-0.0000885 \\
(-0.37)\end{array}$ \\
\hline \multirow{2}{*}{$\begin{array}{l}\text { The ratio of M2 to } \\
\text { International Reserves }\end{array}$} & $-0.00109^{* * *}$ & $-0.00150^{* * * *}$ & $-0.00177 * * *$ & $-0.00177^{* * *}$ & $-0.00137^{* * * *}$ & $-0.00129^{* * *}$ & $-0.00133^{* * *}$ \\
\hline & $(-3.52)$ & $(-3.15)$ & $(-3.12)$ & $(-3.12)$ & $(-2.94)$ & $(-2.73)$ & $(-2.79)$ \\
\hline \multirow{2}{*}{$\begin{array}{l}\text { Total reserves (\% of } \\
\text { total external debt) }\end{array}$} & -0.000118 & -0.000725 & -0.000885 & -0.000885 & $0.000654 *$ & $0.000744 *$ & $0.000706 *$ \\
\hline & $(-0.38)$ & $(-1.52)$ & $(-1.63)$ & $(-1.63)$ & (1.74) & (1.94) & $(1.82)$ \\
\hline GDP per Capita Growth & $\begin{array}{c}0.00000789 \\
(0.04)\end{array}$ & $\begin{array}{c}0.000860^{* * * *} \\
(2.65)\end{array}$ & $\begin{array}{l}0.00101 * * * * \\
\quad(2.76)\end{array}$ & $\begin{array}{l}0.00101 * * * * \\
\quad(2.76)\end{array}$ & $\begin{array}{c}0.000207 \\
(0.86)\end{array}$ & $\begin{array}{c}0.000242 \\
(0.99)\end{array}$ & $\begin{array}{c}0.000348 \\
(1.38)\end{array}$ \\
\hline \multirow{2}{*}{$\begin{array}{l}\text { Domestic credit } \\
\text { provided by banking } \\
\text { sector }\end{array}$} & 0.000216 & -0.000104 & -0.000102 & -0.000102 & 0.000447 & 0.000394 & 0.000398 \\
\hline & $(0.79)$ & $(-0.25)$ & $(-0.21)$ & $(-0.21)$ & (1.18) & (1.04) & (1.05) \\
\hline \multirow{2}{*}{$\begin{array}{l}\text { Reel effective exchange } \\
\text { rate }\end{array}$} & -0.000610 & $-0.00120^{*}$ & $-0.00182 * *$ & $-0.00182^{* *}$ & 0.000742 & 0.000706 & 0.000750 \\
\hline & $(-1.51)$ & $(-1.94)$ & $(-2.26)$ & $(-2.26)$ & (1.42) & (1.36) & (1.43) \\
\hline Inflation Rate & $\begin{array}{c}0.000145 \\
(0.70)\end{array}$ & $\begin{array}{c}0.000672 * * \\
(2.12)\end{array}$ & $\begin{array}{c}0.000642 * \\
(1.83)\end{array}$ & $\begin{array}{c}0.000642^{*} \\
(1.83)\end{array}$ & $\begin{array}{c}0.000154 \\
(0.64)\end{array}$ & $\begin{array}{c}0.000196 \\
(0.80)\end{array}$ & $\begin{array}{c}0.000253 \\
(1.02)\end{array}$ \\
\hline$N$ & 706 & 542 & 504 & 504 & 504 & 514 & 514 \\
\hline
\end{tabular}

$t$ statistics in parentheses

$* p<0.1, * * p<0.05, * * * p<0.01$

Estimates are fixed effect panel estimation results

Using a nonparametric bootstrap, Stata provides a heteroscedasticity robust covariance

Table A3.2: Regressions with the Ratio of Foreign Direct Investments to GDP

\begin{tabular}{|c|c|c|c|c|c|c|c|c|}
\hline & Def1 & Def2 & Def3 & Def4 & Def5 & Def6 & Def7 & Def8 \\
\hline $\begin{array}{l}\text { The ratio of } \\
\text { M2 to } \\
\text { International } \\
\text { Reserves }\end{array}$ & $\begin{array}{c}-0.00119 * * * \\
(-3.93)\end{array}$ & $\begin{array}{c}-0.00112^{* * * *} \\
(-3.00)\end{array}$ & $\begin{array}{c}-0.000690 \\
(-1.61)\end{array}$ & $\begin{array}{c}-0.000908 \\
(-1.39)\end{array}$ & $\begin{array}{c}-0.000834 * * * \\
(-2.62)\end{array}$ & $\begin{array}{c}-0.000886^{* * *} \\
(-2.23)\end{array}$ & $\begin{array}{c}-0.000439 \\
(-0.93)\end{array}$ & $\begin{array}{c}-0.000919 \\
(-1.43)\end{array}$ \\
\hline $\begin{array}{l}\text { Total reserves } \\
\text { (\% of total } \\
\text { external debt) }\end{array}$ & $\begin{array}{c}-0.000108 \\
(-0.44)\end{array}$ & $\begin{array}{c}-0.000369 \\
(-1.15)\end{array}$ & $\begin{array}{c}-0.000709^{*} \\
(-1.84)\end{array}$ & $\begin{array}{c}-0.000584 \\
(-1.21)\end{array}$ & $\begin{array}{c}0.00000307 \\
(0.01)\end{array}$ & $\begin{array}{c}-0.000405 \\
(-1.10)\end{array}$ & $\begin{array}{c}-0.000518 \\
(-1.19)\end{array}$ & $\begin{array}{c}-0.000624 \\
(-1.30)\end{array}$ \\
\hline $\begin{array}{l}\text { GDP per } \\
\text { Capita Growth }\end{array}$ & $\begin{array}{c}-0.000246^{*} \\
(-1.66)\end{array}$ & $\begin{array}{c}-0.000564^{* * * * *} \\
(-2.84)\end{array}$ & $\begin{array}{c}-0.000567 * * \\
(-2.41)\end{array}$ & $\begin{array}{c}-0.000294 \\
(-1.02)\end{array}$ & $\begin{array}{c}-0.000280^{*} \\
(-1.70)\end{array}$ & $\begin{array}{c}-0.000680^{* * * *} \\
(-3.01)\end{array}$ & $\begin{array}{c}-0.000632^{* * *} \\
(-2.40)\end{array}$ & $\begin{array}{c}-0.000296 \\
(-1.03)\end{array}$ \\
\hline $\begin{array}{l}\text { Domestic } \\
\text { credit provided } \\
\text { by banking } \\
\text { sector }\end{array}$ & $\begin{array}{c}0.000690^{* * *} \\
(2.53)\end{array}$ & $\begin{array}{c}0.000748 * * \\
(2.23)\end{array}$ & $\begin{array}{c}0.000238 \\
(0.65)\end{array}$ & $\begin{array}{c}0.000749 \\
(1.33)\end{array}$ & $\begin{array}{c}0.000345 \\
(1.24)\end{array}$ & $\begin{array}{c}0.000473 \\
(1.39)\end{array}$ & $\begin{array}{c}0.000131 \\
(0.34)\end{array}$ & $\begin{array}{c}0.000850 \\
(1.49)\end{array}$ \\
\hline $\begin{array}{l}\text { Reel effective } \\
\text { exchange rate }\end{array}$ & $\begin{array}{c}0.000377 \\
(1.06)\end{array}$ & $\begin{array}{c}0.000545 \\
(1.07)\end{array}$ & $\begin{array}{c}0.000852 \\
(1.33)\end{array}$ & $\begin{array}{c}0.000559 \\
(0.64)\end{array}$ & $\begin{array}{c}0.000247 \\
(0.62)\end{array}$ & $\begin{array}{c}0.0000361 \\
(0.07)\end{array}$ & $\begin{array}{c}0.000700 \\
(1.02)\end{array}$ & $\begin{array}{c}0.000724 \\
(0.84)\end{array}$ \\
\hline Inflation Rate & $\begin{array}{c}0.000149 \\
(0.88)\end{array}$ & $\begin{array}{c}0.000109 \\
(0.48)\end{array}$ & $\begin{array}{c}0.000248 \\
(0.92)\end{array}$ & $\begin{array}{c}-0.0000134 \\
(-0.04)\end{array}$ & $\begin{array}{c}0.000108 \\
(0.57)\end{array}$ & $\begin{array}{c}-0.00000501 \\
(-0.02)\end{array}$ & $\begin{array}{c}0.0000894 \\
(0.30)\end{array}$ & $\begin{array}{c}-0.0000711 \\
(-0.21)\end{array}$ \\
\hline $\begin{array}{l}\text { The ratio of } \\
\text { foreign direct } \\
\text { investments to } \\
\text { GDP }\end{array}$ & $\begin{array}{c}-0.000173 \\
(-0.98)\end{array}$ & $\begin{array}{c}-0.000311 \\
(-1.38)\end{array}$ & $\begin{array}{c}-0.000380 \\
(-1.47)\end{array}$ & $\begin{array}{c}-0.000663^{*} \\
(-1.77)\end{array}$ & $\begin{array}{c}-0.0000267 \\
(-0.14)\end{array}$ & $\begin{array}{c}-0.000162 \\
(-0.66)\end{array}$ & $\begin{array}{c}-0.000294 \\
(-1.03)\end{array}$ & $\begin{array}{c}-0.000692 * \\
(-1.86)\end{array}$ \\
\hline$N$ & 1058 & 655 & 582 & 341 & 1056 & 653 & 580 & 341 \\
\hline
\end{tabular}

$t$ statistics in parentheses

$* p<0.1, * * p<0.05, * * * p<0.01$

Estimates are fixed effect panel estimation results

Using a nonparametric bootstrap, Stata provides a heteroscedasticity robust covariance 


\begin{tabular}{|c|c|c|c|c|c|c|c|}
\hline & Def9 & \multicolumn{2}{|r|}{ Def10 } & Def11 & \multicolumn{2}{|c|}{ Def12 } & Def13 \\
\hline \multirow{2}{*}{$\begin{array}{l}\text { The ratio of M2 to } \\
\text { International Reserves }\end{array}$} & 0.0000602 & \multicolumn{2}{|r|}{-0.000393} & -0.0000362 & \multicolumn{2}{|c|}{0.000667} & -0.000669 \\
\hline & $(0.17)$ & \multicolumn{2}{|r|}{$(-1.03)$} & $(-0.11)$ & \multicolumn{2}{|c|}{$(0.82)$} & $(-1.53)$ \\
\hline \multirow{2}{*}{$\begin{array}{l}\text { Total reserves ( } \% \text { of } \\
\text { total external debt) }\end{array}$} & 0.000302 & \multicolumn{2}{|r|}{0.000186} & 0.000287 & \multicolumn{2}{|c|}{-0.000437} & 0.000363 \\
\hline & $(0.93)$ & \multicolumn{2}{|r|}{ (0.59) } & (1.05) & \multicolumn{2}{|c|}{$(-0.50)$} & (1.05) \\
\hline GDP per Capita Growth & $\begin{array}{c}-0.000364 * \\
(-1.77)\end{array}$ & \multicolumn{2}{|r|}{$\begin{array}{c}0.000334 * \\
(1.70)\end{array}$} & $\begin{array}{l}0.000128 \\
(0.75)\end{array}$ & \multicolumn{2}{|c|}{$\begin{array}{c}0.000239 \\
(0.38)\end{array}$} & $\begin{array}{l}0.000398^{*} \\
(1.78)\end{array}$ \\
\hline $\begin{array}{l}\text { Domestic credit } \\
\text { provided by banking } \\
\text { sector }\end{array}$ & $\begin{array}{l}0.000788^{* *} \\
\quad(2.28)\end{array}$ & \multicolumn{2}{|r|}{$\begin{array}{c}0.000455 \\
(1.47)\end{array}$} & $\begin{array}{c}-0.000281 \\
(-1.18)\end{array}$ & \multicolumn{2}{|c|}{$\begin{array}{l}-0.0000150 \\
(-0.02)\end{array}$} & $\begin{array}{c}0.000205 \\
(0.61)\end{array}$ \\
\hline $\begin{array}{l}\text { Reel effective exchange } \\
\text { rate }\end{array}$ & $\begin{array}{c}-0.00000818 \\
(-0.02)\end{array}$ & \multicolumn{2}{|r|}{$\begin{array}{l}-0.000335 \\
(-0.66)\end{array}$} & $\begin{array}{c}-0.00112 * * \\
(-2.41)\end{array}$ & \multicolumn{2}{|c|}{$\begin{array}{l}-0.000142 \\
(-0.09)\end{array}$} & $\begin{array}{c}0.000433 \\
(0.92)\end{array}$ \\
\hline Inflation Rate & $\begin{array}{c}-0.000238 \\
(-1.09)\end{array}$ & \multicolumn{2}{|r|}{$\begin{array}{c}0.0000684 \\
(0.35)\end{array}$} & $\begin{array}{l}-0.000443 * * \\
(-2.54)\end{array}$ & \multicolumn{2}{|c|}{$\begin{array}{l}-0.000689 \\
(-1.01)\end{array}$} & $\begin{array}{c}0.000188 \\
(0.83)\end{array}$ \\
\hline $\begin{array}{l}\text { The ratio of foreign } \\
\text { direct investments to } \\
\text { GDP }\end{array}$ & $\begin{array}{c}-0.000239 \\
(-1.15)\end{array}$ & \multicolumn{2}{|r|}{$\begin{array}{l}-0.000802^{* * * *} \\
(-3.43)\end{array}$} & $\begin{array}{c}-0.000626 * * * \\
(-3.15)\end{array}$ & \multicolumn{2}{|c|}{$-0.000939 *(-1.68)$} & $\begin{array}{c}-0.000869^{* * * *} \\
(-3.37)\end{array}$ \\
\hline \multicolumn{2}{|c|}{$\begin{array}{ll}N & 989 \\
\text { statistics in parentheses }\end{array}$} & \multicolumn{2}{|r|}{783} & 774 & \multicolumn{2}{|c|}{168} & 764 \\
\hline \multicolumn{8}{|c|}{$\begin{array}{l}t \text { statistics in parentheses } \\
* p<0.1, * * p<0.05, * * * p<0.01 \\
\text { Estimates are fixed effect panel estimation results } \\
\text { Using a nonparametric bootstrap, Stata provides a }\end{array}$} \\
\hline & Def14 & Def15 & Def16 & Def17 & Def18 & Def19 & Def 20 \\
\hline \multirow{2}{*}{$\begin{array}{l}\text { The ratio of } \mathrm{M} 2 \text { to } \\
\text { International reserves }\end{array}$} & $-0.00109^{* * * *}$ & $-0.00146 * * *$ & $-0.00175 * * *$ & $-0.00175^{* * *}$ & $-0.00163 * * *$ & $-0.00166^{* * *}$ & $-0.00166^{* * * *}$ \\
\hline & $(-3.51)$ & $(-3.19)$ & $(-3.27)$ & $(-3.27)$ & $(-3.04)$ & $(-3.01)$ & $(-3.01)$ \\
\hline \multirow{2}{*}{$\begin{array}{l}\text { Total debt (\% of total } \\
\text { external debt) }\end{array}$} & -0.000115 & -0.000524 & -0.000686 & -0.000686 & -0.000679 & -0.000590 & -0.000590 \\
\hline & $(-0.39)$ & $(-1.23)$ & $(-1.45)$ & $(-1.45)$ & $(-1.42)$ & $(-1.22)$ & $(-1.22)$ \\
\hline GDP Growth per capita & $\begin{array}{l}0.0000942 \\
(0.51)\end{array}$ & $\begin{array}{l}0.000785^{* * * *} \\
(2.82)\end{array}$ & $\begin{array}{l}0.000990^{* * * *} \\
(3.13)\end{array}$ & $\begin{array}{l}0.000990 * * * \\
(3.13)\end{array}$ & $\begin{array}{l}0.000989^{* * * *} \\
(3.09)\end{array}$ & $\begin{array}{l}0.000957^{* * *} \\
(3.00)\end{array}$ & $\begin{array}{c}0.000957^{* * * *} \\
(3.00)\end{array}$ \\
\hline \multirow{2}{*}{$\begin{array}{l}\text { Domestic credit } \\
\text { provided by banking } \\
\text { sector }\end{array}$} & 0.000284 & 0.0000159 & 0.0000182 & 0.0000182 & -0.0000253 & 0.000128 & 0.000128 \\
\hline & (1.04) & $(0.04)$ & $(0.04)$ & $(0.04)$ & $(-0.05)$ & $(0.26)$ & $(0.26)$ \\
\hline \multirow{2}{*}{$\begin{array}{l}\text { Reel effective exchange } \\
\text { rate }\end{array}$} & -0.000398 & -0.000751 & $-0.00119 *$ & $-0.00119^{*}$ & $-0.00123^{*}$ & $-0.00118^{*}$ & $-0.00118^{*}$ \\
\hline & $(-1.01)$ & $(-1.37)$ & $(-1.79)$ & $(-1.79)$ & $(-1.82)$ & $(-1.75)$ & $(-1.75)$ \\
\hline Inflation rate & $\begin{array}{c}0.0000740 \\
(0.38)\end{array}$ & $\begin{array}{c}0.000461^{*} \\
(1.71)\end{array}$ & $\begin{array}{c}0.000422 \\
(1.43)\end{array}$ & $\begin{array}{c}0.000422 \\
(1.43)\end{array}$ & $\begin{array}{c}0.000441 \\
(1.49)\end{array}$ & $\begin{array}{c}0.000481 \\
(1.60)\end{array}$ & $\begin{array}{c}0.000481 \\
(1.60)\end{array}$ \\
\hline \multirow{2}{*}{$\begin{array}{l}\text { The ratio of foreign } \\
\text { direct investments to } \\
\text { GDP }\end{array}$} & $-0.000378^{*}$ & $-0.000608 * *$ & $-0.000674 * *$ & $-0.000674 * *$ & $-0.000659^{*}$ & $-0.000710^{* * *}$ & $-0.000710^{* * *}$ \\
\hline & $(-1.80)$ & $(-1.99)$ & $(-1.96)$ & $(-1.96)$ & $(-1.92)$ & $(-2.02)$ & $(-2.02)$ \\
\hline$N$ & 800 & 685 & 647 & 647 & 647 & 647 & 647 \\
\hline
\end{tabular}

$t$ statistics in parentheses

$* p<0.1, * * p<0.05, * * * p<0.01$

Estimates are fixed effect panel estimation results

Using a nonparametric bootstrap, Stata provides a heteroscedasticity robust covariance

Table A3.3: Regressions with Portfolio Equity Net Inflows (BoP, current US\$)

\begin{tabular}{|c|c|c|c|c|c|c|c|c|}
\hline & Def1 & Def2 & Def3 & Def4 & Def5 & Def6 & Def7 & Def8 \\
\hline \multirow{2}{*}{$\begin{array}{l}\text { The ratio of } \mathrm{M} 2 \text { to } \\
\text { International reserves }\end{array}$} & $-0.00204 * * *$ & $-0.00239 * * *$ & $-0.00219 * * *$ & $-0.00218^{* * * *}$ & $-0.00135^{* * *}$ & $-0.00176^{* * *}$ & $-0.00147^{* *}$ & $-0.00224 * * *$ \\
\hline & $(-5.02)$ & $(-4.38)$ & $(-3.17)$ & $(-2.72)$ & $(-3.46)$ & $(-3.34)$ & $(-2.23)$ & $(-2.77)$ \\
\hline \multirow{2}{*}{$\begin{array}{l}\text { Total debt (\% of total } \\
\text { external debt) }\end{array}$} & -0.000191 & $-0.000730 *$ & $-0.00173 * * *$ & -0.000150 & -0.000334 & $-0.000992 * *$ & $-0.00147 * *$ & -0.000260 \\
\hline & $(-0.65)$ & $(-1.73)$ & $(-3.10)$ & $(-0.22)$ & $(-1.04)$ & $(-2.15)$ & $(-2.57)$ & $(-0.38)$ \\
\hline GDP Growth per capita & $\begin{array}{c}-0.000237 \\
(-1.34)\end{array}$ & $\begin{array}{c}-0.000847 * * * * \\
(-3.25)\end{array}$ & $\begin{array}{c}-0.000927 * * * * \\
(-2.75)\end{array}$ & $\begin{array}{c}-0.000392 \\
(-1.00)\end{array}$ & $\begin{array}{c}-0.000314 * \\
(-1.66)\end{array}$ & $\begin{array}{c}-0.000982 * * * * \\
(-3.45)\end{array}$ & $\begin{array}{c}-0.00110^{* * * *} \\
(-3.09)\end{array}$ & $\begin{array}{c}-0.000381 \\
(-0.97)\end{array}$ \\
\hline
\end{tabular}




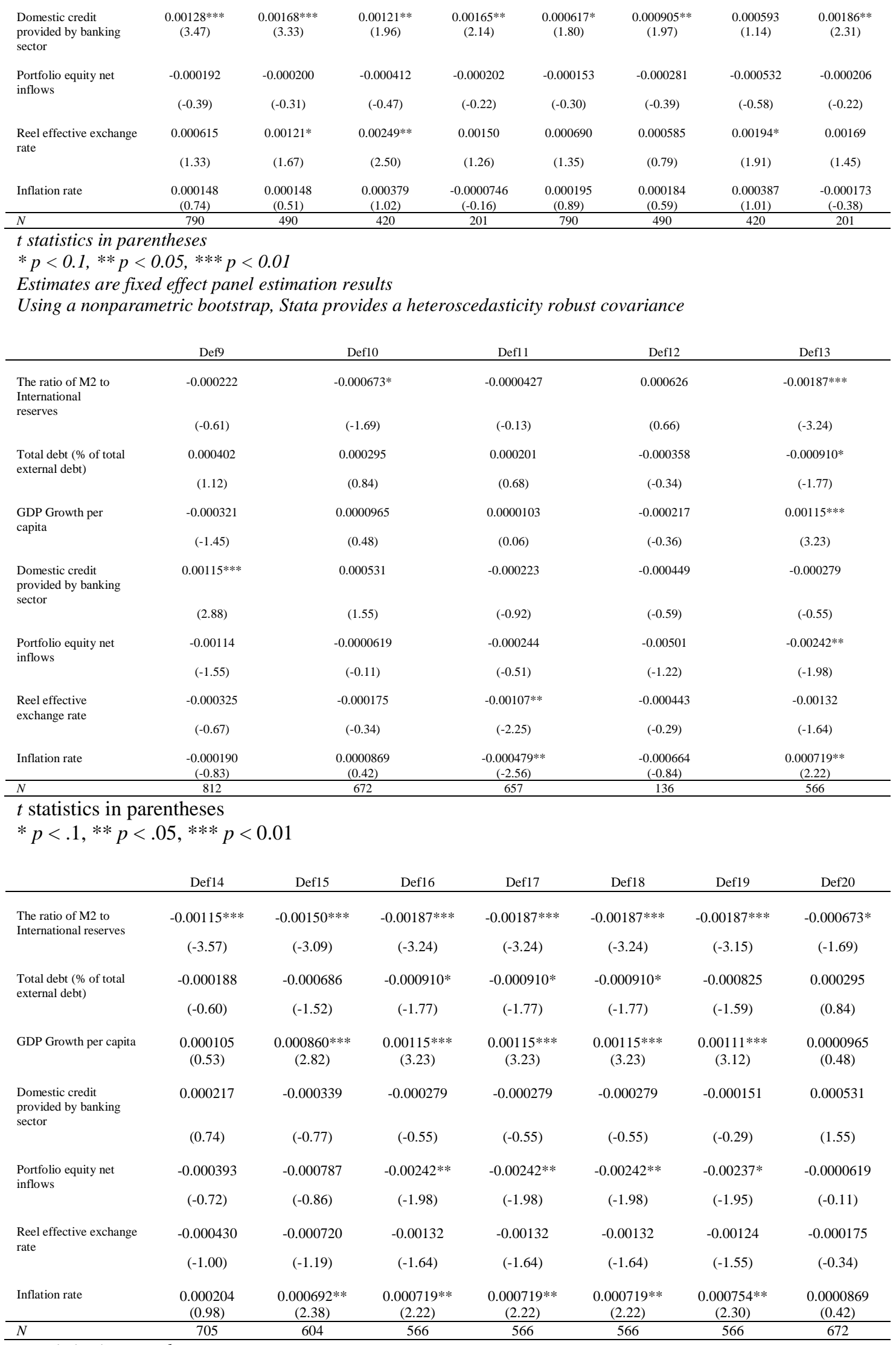

$t$ statistics in parentheses

$* p<0.1, * * p<0.05, * * * p<0.01$

Estimates are fixed effect panel estimation results

Using a nonparametric bootstrap, Stata provides a heteroscedasticity robust covariance 


\section{A4. PREDICTION POWER RESULTS OF THE ROBUSTNESS TESTS}

Table A4.1: Robustness Test Results at 50\% Probability Threshold According to Currency Crisis Definitions, Exports of Goods and Services (Annual \% Growth)

\begin{tabular}{|c|c|c|c|c|c|c|c|c|c|c|c|c|c|c|c|c|c|c|c|c|}
\hline & \multicolumn{8}{|c|}{ Depreciation Rate Based Currency Crisis Definitions } & \multicolumn{5}{|c|}{$\begin{array}{l}\text { Exchange Market Pressure Index Based Currency } \\
\text { Crisis Definitions with Varying Variables }\end{array}$} & \multicolumn{7}{|c|}{$\begin{array}{l}\text { Exchange Market Pressure Index Based Currency Crisis Definitions } \\
\text { with Varying Standard Deviation Multiplier }\end{array}$} \\
\hline & Def1 & Def2 & Def3 & Def4 & Def5 & Def6 & Def7 & Def8 & Def9 & Def10 & Def11 & Def12 & Def13 & Def14 & Def15 & Def16 & Def17 & Def18 & Def19 & Def20 \\
\hline Total Number of Currency Crises ${ }^{\mathrm{A}}$ & 187 & 116 & 82 & 41 & 138 & 87 & 66 & 42 & 106 & 122 & 213 & 26 & 113 & 134 & 74 & 65 & 64 & 62 & 59 & 57 \\
\hline $\begin{array}{l}\text { Correctly Predicted Currency } \\
\text { Crises Episodes }{ }^{3}\end{array}$ & 117 & 78 & 55 & 24 & 86 & 59 & 41 & 24 & 72 & 75 & 103 & 14 & 76 & 68 & 39 & 43 & 41 & 35 & 38 & 37 \\
\hline $\begin{array}{l}\text { Total Number of the Missing Crisis } \\
\text { Episodes }{ }^{c}\end{array}$ & 70 & 38 & 27 & 17 & 52 & 28 & 25 & 18 & 34 & 47 & 110 & 12 & 37 & 66 & 35 & 22 & 23 & 27 & 21 & 20 \\
\hline $\begin{array}{l}\text { The Ratio of the Correctly } \\
\text { Predicted Currency Crisis Episodes } \\
\text { D }\end{array}$ & $62,6 \%$ & $67,2 \%$ & $67,1 \%$ & $58,5 \%$ & $62,3 \%$ & $67,8 \%$ & $62,1 \%$ & $57,1 \%$ & $49,1 \%$ & $61,5 \%$ & $48,4 \%$ & $53,8 \%$ & $67,3 \%$ & $50,7 \%$ & $52,7 \%$ & $66,2 \%$ & $64,1 \%$ & $56,5 \%$ & $64,4 \%$ & $64,9 \%$ \\
\hline $\begin{array}{l}\text { Total Number of Non-Crises } \\
\text { Episodes }\end{array}$ & 2298 & 2369 & 2403 & 2426 & 2329 & 2380 & 2401 & 2425 & 2397 & 1469 & 1444 & 2324 & 1625 & 1619 & 1678 & 1688 & 1689 & 1694 & 1694 & 1691 \\
\hline $\begin{array}{l}\text { Correctly Predicted Non-Currency } \\
\text { Crises Episodes }\end{array}$ & 1142 & 1178 & 1195 & 999 & 1110 & 1014 & 992 & 983 & 1327 & 633 & 596 & 918 & 647 & 815 & 879 & 899 & 907 & 921 & 923 & 924 \\
\hline Total False Alarms ${ }^{\mathrm{G}}$ & 1156 & 1191 & 1208 & 1427 & 1219 & 1366 & 1409 & 1442 & 1070 & 836 & 848 & 1406 & 978 & 804 & 799 & 789 & 782 & 773 & 771 & 767 \\
\hline $\begin{array}{l}\text { The Ratio of the Correctly } \\
\text { Predicted Non-Currency Crisis }^{\text {Episodes }}{ }^{\mathrm{H}}\end{array}$ & $49,7 \%$ & $49,7 \%$ & $49,7 \%$ & $41,2 \%$ & $47,7 \%$ & $42,6 \%$ & $41,3 \%$ & $40,5 \%$ & $55,4 \%$ & $43,1 \%$ & $41,3 \%$ & $39,5 \%$ & $39,8 \%$ & $50,3 \%$ & $52,4 \%$ & $53,3 \%$ & $53,7 \%$ & $54,4 \%$ & $54,5 \%$ & $54,6 \%$ \\
\hline Prediction Power of the Model ${ }^{1}$ & $50,7 \%$ & $50,5 \%$ & $50,3 \%$ & $41,5 \%$ & $48,5 \%$ & $43,5 \%$ & $41,9 \%$ & $40,8 \%$ & $55,9 \%$ & $44,5 \%$ & $42,2 \%$ & $39,7 \%$ & $41,6 \%$ & $50,4 \%$ & $52,4 \%$ & $53,7 \%$ & $54,1 \%$ & $54,4 \%$ & $54,8 \%$ & $55,0 \%$ \\
\hline Type II Error ${ }^{\mathrm{K}}$ & $50,3 \%$ & $50,3 \%$ & $50,3 \%$ & $58,8 \%$ & $52,3 \%$ & $57,4 \%$ & $58,7 \%$ & $59,5 \%$ & $44,6 \%$ & $56,9 \%$ & $58,7 \%$ & $60,5 \%$ & $60,2 \%$ & $49,7 \%$ & $47,6 \%$ & $46,7 \%$ & $46,3 \%$ & $45,6 \%$ & $45,5 \%$ & $45,4 \%$ \\
\hline
\end{tabular}

A: Total number of the actual currency crisis episodes according to EWS models

B: Total Number of the Correctly Predicted Currency Crisis Episodes according to EWS models under 50\% Probability Threshold

C: Total Number of Currency Crises Episodes-Correctly Predicted Currency Crises Episodes

D: Correctly Predicted Currency Crises Episodes/ Total Number of Currency Crises Episodes

E: Total number of the actual number of non-currency crisis according to EWS models
F: Total Number of the Correctly Predicted non-Currency Crisis Episodes according to EWS models under 50\% Probability Threshold
G: Total Number of non- Currency Crises Episodes- Correctly Predicted non-Currency Crises Episodes H: Correctly Predicted non-Currency Crises Episodes/ Total Number of non-Currency Crises Episodes

I: Total Number of Correctly Predicted Currency Crisis and non-Currency Crisis Episodes/Total Number of Currency and non-Currency Crisis Episodes

J: Type 1 Error: Total Number of Missed Currency Crisis Episodes/ Total Number of Currency Crisis Episodes

K: Type 2 Error: Total false alarms/ Total Number of non- Currency Crises Episodes 
Table A4.2: Robustness Test Results at 50\% Probability Threshold According to Currency Crisis Definitions, The Ratio of Foreign Direct Investments to GDP

\begin{tabular}{|c|c|c|c|c|c|c|c|c|c|c|c|c|c|c|c|c|c|c|c|c|}
\hline & \multicolumn{8}{|c|}{ Depreciation Rate Based Currency Crisis Definitions } & \multicolumn{5}{|c|}{$\begin{array}{l}\text { Exchange Market Pressure Index Based } \\
\text { Currency Crisis Definitions with Varying } \\
\text { Variables }\end{array}$} & \multicolumn{7}{|c|}{$\begin{array}{l}\text { Exchange Market Pressure Index Based Currency Crisis Definitions } \\
\text { with Varying Standard Deviation Multiplier }\end{array}$} \\
\hline & Def1 & Def2 & Def3 & Def4 & Def5 & Def6 & Def7 & Def8 & Def9 & Def10 & Def11 & Def12 & Def13 & Def14 & Def15 & Def16 & Def17 & Def18 & Def19 & Def20 \\
\hline Total Number of Currency Crises & 187 & 116 & 82 & 41 & 138 & 87 & 66 & 42 & 106 & 122 & 213 & 26 & 113 & 134 & 74 & 65 & 64 & 62 & 59 & 57 \\
\hline $\begin{array}{l}\text { Correctly Predicted Currency } \\
\text { Crises Episodes }\end{array}$ & 116 & 73 & 54 & 22 & 83 & 57 & 44 & 24 & 68 & 78 & 103 & 14 & 76 & 69 & 37 & 42 & 43 & 40 & 36 & 39 \\
\hline $\begin{array}{l}\text { Total Number of the Missing } \\
\text { Crisis Episodes }{ }^{\mathrm{c}}\end{array}$ & 71 & 43 & 28 & 19 & 55 & 30 & 22 & 18 & 38 & 44 & 110 & 12 & 37 & 65 & 37 & 23 & 21 & 22 & 23 & 18 \\
\hline $\begin{array}{l}\text { The Ratio of the Correctly } \\
\text { Predicted Currency Crisis } \\
\text { Episodes }\end{array}$ & $62,0 \%$ & $62,9 \%$ & $65,9 \%$ & $53,7 \%$ & $60,1 \%$ & $65,5 \%$ & $66,7 \%$ & $57,1 \%$ & $49,1 \%$ & $63,9 \%$ & $48,4 \%$ & $53,8 \%$ & $67,3 \%$ & $51,5 \%$ & $50,0 \%$ & $64,6 \%$ & $67,2 \%$ & $64,5 \%$ & $61,0 \%$ & $68,4 \%$ \\
\hline $\begin{array}{l}\text { Total Number of Non-Crises } \\
\text { Episodes }{ }^{\mathrm{E}}\end{array}$ & 2298 & 2369 & 2403 & 2426 & 2329 & 2380 & 2401 & 2425 & 2397 & 1469 & 1444 & 2324 & 1625 & 1619 & 1678 & 1688 & 1689 & 1694 & 1694 & 1691 \\
\hline $\begin{array}{l}\text { Correctly Predicted Non- } \\
\text { Currency Crises Episodes } \mathrm{F}\end{array}$ & 1141 & 1177 & 1190 & 996 & 1005 & 1013 & 888 & 891 & 1329 & 629 & 581 & 913 & 647 & 811 & 879 & 898 & 901 & 917 & 923 & 920 \\
\hline Total False Alarms ${ }^{G}$ & 1157 & 1192 & 1213 & 1430 & 1324 & 1367 & 1513 & 1534 & 1068 & 840 & 863 & 1411 & 978 & 808 & 799 & 790 & 788 & 777 & 771 & 771 \\
\hline $\begin{array}{l}\text { The Ratio of the Correctly } \\
\text { Predicted Non-Currency Crisis } \\
\text { Episodes }{ }^{\mathrm{H}}\end{array}$ & $49,7 \%$ & $49,7 \%$ & $49,5 \%$ & $41,1 \%$ & $43,2 \%$ & $42,6 \%$ & $37,0 \%$ & $36,7 \%$ & $55,4 \%$ & $42,8 \%$ & $40,2 \%$ & $39,3 \%$ & $39,8 \%$ & $50,1 \%$ & $52,4 \%$ & $53,2 \%$ & $53,3 \%$ & $54,1 \%$ & $54,5 \%$ & $54,4 \%$ \\
\hline Prediction Power of the Model ${ }^{1}$ & $50,6 \%$ & $50,3 \%$ & $50,1 \%$ & $41,3 \%$ & $44,1 \%$ & $43,4 \%$ & $37,8 \%$ & $37,1 \%$ & $55,8 \%$ & $44,4 \%$ & $41,3 \%$ & $39,4 \%$ & $41,6 \%$ & $50,2 \%$ & $52,3 \%$ & $53,6 \%$ & $53,9 \%$ & $54,5 \%$ & $54,7 \%$ & $54,9 \%$ \\
\hline Type I Error ${ }^{J}$ & $38,0 \%$ & $37,1 \%$ & $34,1 \%$ & $46,3 \%$ & $39,9 \%$ & $34,5 \%$ & $33,3 \%$ & $42,9 \%$ & $35,8 \%$ & $36,1 \%$ & $51,6 \%$ & $46,2 \%$ & $32,7 \%$ & $48,5 \%$ & $50,0 \%$ & $35,4 \%$ & $32,8 \%$ & $35,5 \%$ & $39,0 \%$ & $31,6 \%$ \\
\hline Type II Error ${ }^{\mathrm{K}}$ & $50,3 \%$ & $50,3 \%$ & $50,5 \%$ & $58,9 \%$ & $56,8 \%$ & $57,4 \%$ & $63,0 \%$ & $63,3 \%$ & $44,6 \%$ & $57,2 \%$ & $59,8 \%$ & $60,7 \%$ & $60,2 \%$ & $49,9 \%$ & $47,6 \%$ & $46,8 \%$ & $46,7 \%$ & $45,9 \%$ & $45,5 \%$ & $45,6 \%$ \\
\hline
\end{tabular}

A: Total number of the actual currency crisis episodes according to EWS models

G: Total Number of non- Currency Crises Episodes- Correctly Predicted non-Currency Crises Episodes

B: Total Number of the Correctly Predicted Currency Crisis Episodes according to EWS models under 50\% Probability Threshold

H: Correctly Predicted non-Currency Crises Episodes/ Total Number of non-Currency Crises Episodes

C: Total Number of Currency Crises Episodes-Correctly Predicted Currency Crises Episodes

D: Correctly Predicted Currency Crises Episodes/ Total Number of Currency Crises Episodes Episodes

I: Total Number of Correctly Predicted Currency Crisis and non-Currency Crisis Episodes/Total Number of Currency and non-Currency Crisis Episodes

E: Total number of the actual number of non-currency crisis according to EWS models

K: Type 2 Error: Total false alarms/ Total Number of non- Currency Crises Episodes

F: Total Number of the Correctly Predicted non-Currency Crisis Episodes according to EWS models under 50\% Probability Threshold 
Table A4.3: Robustness Test Results at 50\% Probability Threshold According to Currency Crisis Definitions, Portfolio Equity Net Inflows

\begin{tabular}{|c|c|c|c|c|c|c|c|c|c|c|c|c|c|c|c|c|c|c|c|c|}
\hline & \multicolumn{8}{|c|}{ Depreciation Rate Based Currency Crisis Definitions } & \multicolumn{5}{|c|}{$\begin{array}{l}\text { Exchange Market Pressure Index Based } \\
\text { Currency Crisis Definitions with Varying } \\
\text { Variables }\end{array}$} & \multicolumn{7}{|c|}{$\begin{array}{l}\text { Exchange Market Pressure Index Based Currency Crisis Definitions } \\
\text { with Varying Standard Deviation Multiplier }\end{array}$} \\
\hline & Def1 & Def2 & Def3 & Def4 & Def5 & Def6 & Def7 & Def8 & Def9 & Def10 & Def11 & Def12 & Def13 & Def14 & Def15 & Def16 & Def17 & Def18 & Def19 & Def20 \\
\hline Total Number of Currency Crises & 187 & 116 & 82 & 41 & 138 & 87 & 66 & 42 & 106 & 122 & 213 & 26 & 113 & 134 & 74 & 65 & 64 & 62 & 59 & 57 \\
\hline $\begin{array}{l}\text { Correctly Predicted Currency } \\
\text { Crises Episodes }^{\mathrm{B}}\end{array}$ & 118 & 78 & 56 & 21 & 86 & 56 & 44 & 23 & 69 & 72 & 106 & 14 & 73 & 67 & 39 & 43 & 42 & 39 & 38 & 37 \\
\hline $\begin{array}{l}\text { Total Number of the Missing } \\
\text { Crisis Episodes }{ }^{\mathrm{C}}\end{array}$ & 69 & 38 & 26 & 20 & 52 & 31 & 22 & 19 & 37 & 50 & 107 & 12 & 40 & 67 & 35 & 22 & 22 & 23 & 21 & 20 \\
\hline $\begin{array}{l}\text { The Ratio of the Correctly } \\
\text { Predicted Currency Crisis } \\
\text { Episodes }{ }^{\mathrm{D}}\end{array}$ & $62,0 \%$ & $62,9 \%$ & $65,9 \%$ & $53,7 \%$ & $60,1 \%$ & $65,5 \%$ & $66,7 \%$ & $57,1 \%$ & $49,1 \%$ & $63,9 \%$ & $48,4 \%$ & $53,8 \%$ & $67,3 \%$ & $51,5 \%$ & $50,0 \%$ & $64,6 \%$ & $67,2 \%$ & $64,5 \%$ & $61,0 \%$ & $68,4 \%$ \\
\hline $\begin{array}{l}\text { Total Number of Non-Crises } \\
\text { Episodes }{ }^{\mathrm{E}}\end{array}$ & 2298 & 2369 & 2403 & 2426 & 2329 & 2380 & 2401 & 2425 & 2397 & 1469 & 1444 & 2324 & 1625 & 1619 & 1678 & 1688 & 1689 & 1694 & 1694 & 1691 \\
\hline $\begin{array}{l}\text { Correctly Predicted Non- } \\
\text { Currency Crises Episodes }\end{array}$ & 1141 & 1177 & 1190 & 996 & 1005 & 1013 & 888 & 891 & 1329 & 629 & 581 & 913 & 647 & 811 & 879 & 898 & 901 & 917 & 923 & 920 \\
\hline Total False Alarms ${ }^{\mathrm{G}}$ & 1157 & 1192 & 1213 & 1430 & 1324 & 1367 & 1513 & 1534 & 1068 & 840 & 863 & 1411 & 978 & 808 & 799 & 790 & 788 & 777 & 771 & 771 \\
\hline $\begin{array}{l}\text { The Ratio of the Correctly } \\
\text { Predicted Non-Currency Crisis } \\
\text { Episodes }{ }^{\mathrm{H}}\end{array}$ & $49,7 \%$ & $49,7 \%$ & $49,5 \%$ & $41,1 \%$ & $43,2 \%$ & $42,6 \%$ & $37,0 \%$ & $36,7 \%$ & $55,4 \%$ & $42,8 \%$ & $40,2 \%$ & $39,3 \%$ & $39,8 \%$ & $50,1 \%$ & $52,4 \%$ & $53,2 \%$ & $53,3 \%$ & $54,1 \%$ & $54,5 \%$ & $54,4 \%$ \\
\hline Prediction Power of the Model ${ }^{1}$ & $50,6 \%$ & $50,3 \%$ & $50,1 \%$ & $41,3 \%$ & $44,1 \%$ & $43,4 \%$ & $37,8 \%$ & $37,1 \%$ & $55,8 \%$ & $44,4 \%$ & $41,3 \%$ & $39,4 \%$ & $41,6 \%$ & $50,2 \%$ & $52,3 \%$ & $53,6 \%$ & $53,9 \%$ & $54,5 \%$ & $54,7 \%$ & $54,9 \%$ \\
\hline Type I Error ${ }^{J}$ & $38,0 \%$ & $37,1 \%$ & $34,1 \%$ & $46,3 \%$ & $39,9 \%$ & $34,5 \%$ & $33,3 \%$ & $42,9 \%$ & $35,8 \%$ & $36,1 \%$ & $51,6 \%$ & $46,2 \%$ & $32,7 \%$ & $48,5 \%$ & $50,0 \%$ & $35,4 \%$ & $32,8 \%$ & $35,5 \%$ & $39,0 \%$ & $31,6 \%$ \\
\hline Type II Error ${ }^{K}$ & $50,3 \%$ & $50,3 \%$ & $50,5 \%$ & $58,9 \%$ & $56,8 \%$ & $57,4 \%$ & $63,0 \%$ & $63,3 \%$ & $44,6 \%$ & $57,2 \%$ & $59,8 \%$ & $60,7 \%$ & $60,2 \%$ & $49,9 \%$ & $47,6 \%$ & $46,8 \%$ & $46,7 \%$ & $45,9 \%$ & $45,5 \%$ & $45,6 \%$ \\
\hline
\end{tabular}

A: Total number of the actual currency crisis episodes according to EWS models

B: Total Number of the Correctly Predicted Currency Crisis Episodes according to EWS models under 50\% Probability Threshold

C: Total Number of Currency Crises Episodes-Correctly Predicted Currency Crises Episodes

D: Correctly Predicted Currency Crises Episodes/ Total Number of Currency Crises Episodes

E: Total number of the actual number of non-currency crisis according to EWS models

F: Total Number of the Correctly Predicted non-Currency Crisis Episodes according to EWS models under 50\% Probability Threshold
G: Total Number of non- Currency Crises Episodes- Correctly Predicted non-Currency Crises H: Correctly Predicted non-Currency Crises Episodes/ Total Number of non-Currency Crises Episodes

I: Total Number of Correctly Predicted Currency Crisis and non-Currency Crisis Episodes/Total Number of Currency and non-Currency Crisis Episodes

J: Type 1 Error: Total Number of Missed Currency Crisis Episodes/ Total Number of Currency Crisis

K. Type 2 Error: Total false alarms/ Total Number of non- Currency Crises Episodes 


\section{A5. EMPIRICAL RESULTS OF THE OUT-OF-SAMPLE ANALYSIS}

\section{Table A5.1: Empirical Results of the Out-of-Sample Analysis}

\begin{tabular}{|c|c|c|c|c|c|c|c|c|}
\hline & Def1 & Def2 & Def3 & Def4 & Def5 & Def6 & Def7 & Def8 \\
\hline $\begin{array}{l}\text { main } \\
\text { m2gdp }\end{array}$ & $\begin{array}{c}-0.00112 * * \\
(-2.23)\end{array}$ & $\begin{array}{c}-0.00142 * * \\
(-2.19)\end{array}$ & $\begin{array}{c}-0.00102 \\
(-1.48)\end{array}$ & $\begin{array}{c}-0.00156 \\
(-1.54)\end{array}$ & $\begin{array}{c}-0.000541 \\
(-1.07)\end{array}$ & $\begin{array}{c}-0.000757 \\
(-1.20)\end{array}$ & $\begin{array}{c}-0.000651 \\
(-0.92)\end{array}$ & $\begin{array}{c}-0.00125 \\
(-1.31)\end{array}$ \\
\hline totres_to_totextdebt & $\begin{array}{c}0.0000924 \\
(0.31)\end{array}$ & $\begin{array}{c}-0.000299 \\
(-0.80)\end{array}$ & $\begin{array}{c}-0.000709 \\
(-1.62)\end{array}$ & $\begin{array}{c}-0.000586 \\
(-1.09)\end{array}$ & $\begin{array}{c}0.000196 \\
(0.58)\end{array}$ & $\begin{array}{c}-0.000231 \\
(-0.54)\end{array}$ & $\begin{array}{c}-0.000575 \\
(-1.15)\end{array}$ & $\begin{array}{c}-0.000597 \\
(-1.13)\end{array}$ \\
\hline GDPgrowthPC & $\begin{array}{c}-0.000191 \\
(-0.98)\end{array}$ & $\begin{array}{c}-0.000265 \\
(-1.09)\end{array}$ & $\begin{array}{c}-0.000199 \\
(-0.71)\end{array}$ & $\begin{array}{c}-0.000170 \\
(-0.49)\end{array}$ & $\begin{array}{c}-0.000273 \\
(-1.23)\end{array}$ & $\begin{array}{c}-0.000445 \\
(-1.59)\end{array}$ & $\begin{array}{c}-0.000228 \\
(-0.72)\end{array}$ & $\begin{array}{c}-0.000149 \\
(-0.43)\end{array}$ \\
\hline DomCredt_bnkgsectr & $\begin{array}{c}0.000942 * * \\
(2.35)\end{array}$ & $\begin{array}{c}0.00122 * * \\
(2.27)\end{array}$ & $\begin{array}{c}0.000883 \\
(1.64)\end{array}$ & $\begin{array}{c}0.000669 \\
(1.02)\end{array}$ & $\begin{array}{c}0.000353 \\
(0.91)\end{array}$ & $\begin{array}{c}0.000897 * \\
(1.72)\end{array}$ & $\begin{array}{c}0.000692 \\
(1.27)\end{array}$ & $\begin{array}{c}0.000829 \\
(1.26)\end{array}$ \\
\hline reer & $\begin{array}{c}-0.000588 \\
(-1.12)\end{array}$ & $\begin{array}{c}0.000231 \\
(0.35)\end{array}$ & $\begin{array}{c}0.000519 \\
(0.69)\end{array}$ & $\begin{array}{c}-0.000218 \\
(-0.21)\end{array}$ & $\begin{array}{c}-0.000618 \\
(-1.05)\end{array}$ & $\begin{array}{c}-0.000427 \\
(-0.58)\end{array}$ & $\begin{array}{c}0.000164 \\
(0.20)\end{array}$ & $\begin{array}{c}0.000104 \\
(0.10)\end{array}$ \\
\hline inflation & $\begin{array}{c}0.0000817 \\
(0.38)\end{array}$ & $\begin{array}{c}0.000227 \\
(0.81) \\
\end{array}$ & $\begin{array}{c}0.000394 \\
(1.20) \\
\end{array}$ & $\begin{array}{c}-0.000219 \\
(-0.53)\end{array}$ & $\begin{array}{c}-0.0000412 \\
(-0.16)\end{array}$ & $\begin{array}{c}0.000163 \\
(0.51)\end{array}$ & $\begin{array}{c}0.000268 \\
(0.72)\end{array}$ & $\begin{array}{c}-0.000293 \\
(-0.72) \\
\end{array}$ \\
\hline$N$ & 567 & 336 & 295 & 166 & 557 & 334 & 293 & 166 \\
\hline
\end{tabular}

t statistics in parentheses

$* p<0.1, * * p<0.05, * * * p<0.01$

Estimates are fixed effect panel estimation results

Using a nonparametric bootstrap, Stata provides a heteroscedasticity robust covariance

\begin{tabular}{|c|c|c|c|c|c|}
\hline & Def9 & Def10 & Def11 & Def12 & Def13 \\
\hline $\begin{array}{l}\text { main } \\
\text { m2gdp }\end{array}$ & $\begin{array}{c}0.00000551 \\
\quad(0.01)\end{array}$ & $\begin{array}{c}-0.000955 \\
(-1.62)\end{array}$ & $\begin{array}{c}-0.000670 \\
(-1.16)\end{array}$ & $\begin{array}{c}0.00122 \\
(1.01)\end{array}$ & $\begin{array}{c}-0.00134 * * \\
\quad(-2.05)\end{array}$ \\
\hline totres_to_totextdebt & $\begin{array}{c}0.0000720 \\
(0.17)\end{array}$ & $\begin{array}{c}0.000634 \\
(1.58)\end{array}$ & $\begin{array}{c}0.000708^{*} \\
\quad(1.76)\end{array}$ & $\begin{array}{c}0.000386 \\
(0.38)\end{array}$ & $\begin{array}{c}0.00112 * * \\
(2.52)\end{array}$ \\
\hline GDPgrowthPC & $\begin{array}{c}-0.000137 \\
(-0.49)\end{array}$ & $\begin{array}{c}0.000361 \\
(1.36)\end{array}$ & $\begin{array}{c}0.000102 \\
(0.41)\end{array}$ & $\begin{array}{c}0.000345 \\
(0.50)\end{array}$ & $\begin{array}{c}0.000318 \\
(1.15)\end{array}$ \\
\hline DomCredt_bnkgsectr & $\begin{array}{c}0.000982 * \\
(1.73)\end{array}$ & $\begin{array}{c}0.000317 \\
(0.74)\end{array}$ & $\begin{array}{c}-0.000269 \\
(-0.83)\end{array}$ & $\begin{array}{c}-0.000810 \\
(-1.05)\end{array}$ & $\begin{array}{c}0.000375 \\
(0.84)\end{array}$ \\
\hline reer & $\begin{array}{c}-0.000370 \\
(-0.64)\end{array}$ & $\begin{array}{c}-0.00113 \\
(-1.33)\end{array}$ & $\begin{array}{c}-0.00163^{*} \\
(-1.73)\end{array}$ & $\begin{array}{c}-0.000947 \\
(-0.49)\end{array}$ & $\begin{array}{c}-0.00158 * \\
(-1.73)\end{array}$ \\
\hline inflation & $\begin{array}{c}-0.000583^{*} \\
(-1.89)\end{array}$ & $\begin{array}{c}0.000129 \\
(0.47) \\
\end{array}$ & $\begin{array}{c}-0.000230 \\
(-0.86)\end{array}$ & $\begin{array}{c}-0.00151 \\
(-1.54)\end{array}$ & $\begin{array}{c}0.000209 \\
(0.70)\end{array}$ \\
\hline$N$ & 443 & 336 & 336 & 72 & 303 \\
\hline
\end{tabular}

$t$ statistics in parentheses

$* p<0.1, * * p<0.05, * * * p<0.01$

Estimates are fixed effect panel estimation results

Using a nonparametric bootstrap, Stata provides a heteroscedasticity robust covariance

\begin{tabular}{|c|c|c|c|c|c|c|c|}
\hline & Def14 & Def15 & Def16 & Def17 & Def18 & Def19 & Def 20 \\
\hline $\begin{array}{l}\text { main } \\
\text { m2gdp }\end{array}$ & $\begin{array}{c}-0.000960 \\
(-1.63)\end{array}$ & $\begin{array}{c}-0.00119 \\
(-1.35)\end{array}$ & $\begin{array}{c}-0.00266 * * \\
(-2.34)\end{array}$ & $\begin{array}{c}-0.00266^{* *} \\
(-2.34)\end{array}$ & $\begin{array}{c}-0.00266 * * \\
(-2.34)\end{array}$ & $\begin{array}{c}-0.00283 * * \\
(-2.27)\end{array}$ & $\begin{array}{c}-0.00283^{* *} \\
(-2.27)\end{array}$ \\
\hline totres_to_totextdebt & $\begin{array}{c}-0.000219 \\
(-0.60)\end{array}$ & $\begin{array}{c}-0.000344 \\
(-0.68)\end{array}$ & $\begin{array}{c}-0.000659 \\
(-1.10)\end{array}$ & $\begin{array}{c}-0.000659 \\
(-1.10)\end{array}$ & $\begin{array}{c}-0.000659 \\
(-1.10)\end{array}$ & $\begin{array}{c}-0.000518 \\
(-0.87)\end{array}$ & $\begin{array}{c}-0.000518 \\
(-0.87)\end{array}$ \\
\hline GDPgrowthPC & $\begin{array}{c}0.000112 \\
(0.49)\end{array}$ & $\begin{array}{c}0.000784 * * \\
(2.42)\end{array}$ & $\begin{array}{c}0.00115^{* * *} \\
(2.91)\end{array}$ & $\begin{array}{c}0.00115^{* * *} \\
(2.91)\end{array}$ & $\begin{array}{c}0.00115 * * * \\
(2.91)\end{array}$ & $\begin{array}{c}0.00109^{* * *} \\
(2.79)\end{array}$ & $\begin{array}{c}0.00109^{* * *} \\
(2.79)\end{array}$ \\
\hline DomCredt_bnkgsectr & $\begin{array}{l}0.000824 * \\
(1.77)\end{array}$ & $\begin{array}{c}0.000578 \\
(0.91)\end{array}$ & $\begin{array}{c}0.000548 \\
(0.74)\end{array}$ & $\begin{array}{c}0.000548 \\
(0.74)\end{array}$ & $\begin{array}{c}0.000548 \\
(0.74)\end{array}$ & $\begin{array}{c}0.000882 \\
(1.05)\end{array}$ & $\begin{array}{c}0.000882 \\
(1.05)\end{array}$ \\
\hline reer & $\begin{array}{c}-0.00191 * * \\
(-2.56)\end{array}$ & $\begin{array}{c}-0.00312^{* *} \\
(-2.53)\end{array}$ & $\begin{array}{c}-0.00513 * * * \\
(-2.71)\end{array}$ & $\begin{array}{c}-0.00513 * * * \\
(-2.71)\end{array}$ & $\begin{array}{c}-0.00513 * * * \\
(-2.71)\end{array}$ & $\begin{array}{c}-0.00469 * * * \\
(-2.63)\end{array}$ & $\begin{array}{c}-0.00469 * * * \\
(-2.63)\end{array}$ \\
\hline inflation & 0.000170 & 0.000505 & 0.000426 & 0.000426 & 0.000426 & 0.000480 & 0.000480 \\
\hline
\end{tabular}




\begin{tabular}{cccccccc} 
& $(0.67)$ & $(1.50)$ & $(1.13)$ & $(1.13)$ & $(1.13)$ & $(1.25)$ & $(1.25)$ \\
\hline$N$ & 382 & 307 & 285 & 285 & 285 & 285 & 285 \\
\hline
\end{tabular}

$t$ statistics in parentheses

$* p<0.1, * * p<0.05, * * * p<0.01$

Estimates are fixed effect panel estimation results

Using a nonparametric bootstrap, Stata provides a heteroscedasticity robust covariance

Table A5.2: Type 1 Errors the Model according to different Crisis Definitions and different Probability Thresholds, Out of Sample Results, Out of Sample

\begin{tabular}{|c|c|c|c|c|c|c|c|c|c|c|c|}
\hline & $\begin{array}{c}\text { Probabili } \\
\text { ty } \\
\text { Threshol } \\
\text { d 1\% }\end{array}$ & $\begin{array}{c}\text { Probabili } \\
\text { ty } \\
\text { Threshol } \\
\text { d 2.5\% } \\
\end{array}$ & $\begin{array}{c}\text { Probabili } \\
\text { ty } \\
\text { Threshol } \\
\text { d 5\% }\end{array}$ & $\begin{array}{c}\text { Probabili } \\
\text { ty } \\
\text { Threshol } \\
\text { d 10\% }\end{array}$ & $\begin{array}{c}\begin{array}{c}\text { Probabili } \\
\text { ty }\end{array} \\
\text { Threshol } \\
\text { d 25\% }\end{array}$ & $\begin{array}{c}\text { Probabili } \\
\text { ty } \\
\text { Threshol } \\
\text { d 50\% }\end{array}$ & $\begin{array}{c}\text { Probabili } \\
\text { ty } \\
\text { Threshol } \\
\text { d 75\% } \\
\end{array}$ & $\begin{array}{c}\text { Probabili } \\
\text { ty } \\
\text { Threshol } \\
\text { d 80\% }\end{array}$ & $\begin{array}{c}\text { Probabili } \\
\text { ty } \\
\text { Threshol } \\
\text { d 85\% }\end{array}$ & $\begin{array}{c}\text { Probabili } \\
\text { ty } \\
\text { Threshol } \\
\text { d 90\% }\end{array}$ & $\begin{array}{c}\text { Probabil } \\
\text { ty } \\
\text { Threshol } \\
\text { d 95\% } \\
\end{array}$ \\
\hline Def 1 & $0.9 \%$ & $12.1 \%$ & $22.3 \%$ & $28.5 \%$ & $35.4 \%$ & $36.7 \%$ & $36.7 \%$ & $36.7 \%$ & $36.7 \%$ & $36.7 \%$ & $36.7 \%$ \\
\hline Def 2 & $3.7 \%$ & $9.9 \%$ & $13.6 \%$ & $22.1 \%$ & $28.2 \%$ & $32.6 \%$ & $32.6 \%$ & $32.6 \%$ & $32.6 \%$ & $32.6 \%$ & $32.6 \%$ \\
\hline Def 3 & $3.5 \%$ & $9.7 \%$ & $10.8 \%$ & $25.7 \%$ & $24.9 \%$ & $30.8 \%$ & $30.8 \%$ & $30.8 \%$ & $30.8 \%$ & $30.8 \%$ & $30.8 \%$ \\
\hline Def 4 & $2.6 \%$ & $9.5 \%$ & $23.9 \%$ & $33.8 \%$ & $41.1 \%$ & $40.9 \%$ & $40.9 \%$ & $40.9 \%$ & $40.9 \%$ & $40.9 \%$ & $40.9 \%$ \\
\hline Def 5 & $0.6 \%$ & $8.3 \%$ & $17.9 \%$ & $28.1 \%$ & $34.6 \%$ & $36.8 \%$ & $36.8 \%$ & $36.8 \%$ & $36.8 \%$ & $36.8 \%$ & $36.8 \%$ \\
\hline Def 6 & $2.1 \%$ & $4.4 \%$ & $10.2 \%$ & $17.1 \%$ & $24.9 \%$ & $31.8 \%$ & $31.8 \%$ & $31.8 \%$ & $31.8 \%$ & $31.8 \%$ & $31.8 \%$ \\
\hline Def 7 & $3.8 \%$ & $6,00 \%$ & $8.9 \%$ & $14.8 \%$ & $27.0 \%$ & $32.6 \%$ & $32.6 \%$ & $32.6 \%$ & $32.6 \%$ & $32.6 \%$ & $32.6 \%$ \\
\hline Def 8 & $4.5 \%$ & $11.1 \%$ & $23.2 \%$ & $35.3 \%$ & $42.3 \%$ & $41.4 \%$ & $41.4 \%$ & $41.4 \%$ & $41.4 \%$ & $41.4 \%$ & $41.4 \%$ \\
\hline Def 9 & $1.2 \%$ & $8.4 \%$ & $18.7 \%$ & $24.3 \%$ & $33.1 \%$ & $36.2 \%$ & $36.2 \%$ & $36.2 \%$ & $36.2 \%$ & $36.2 \%$ & $36.2 \%$ \\
\hline $\begin{array}{c}\text { Def } \\
10\end{array}$ & $2.4 \%$ & $8.9 \%$ & $19.5 \%$ & $33.1 \%$ & $48.6 \%$ & $50.0 \%$ & $50.0 \%$ & $50.0 \%$ & $50.0 \%$ & $50.0 \%$ & $50.0 \%$ \\
\hline $\begin{array}{c}\text { Def } \\
11\end{array}$ & $1.6 \%$ & $12.3 \%$ & $33.1 \%$ & $42.2 \%$ & $43.9 \%$ & $45.2 \%$ & $45.2 \%$ & $45.2 \%$ & $45.2 \%$ & $45.2 \%$ & $45.2 \%$ \\
\hline $\begin{array}{c}\text { Def } \\
12\end{array}$ & $1.1 \%$ & $6.7 \%$ & $18.9 \%$ & $35.6 \%$ & $47.7 \%$ & $50.0 \%$ & $50.0 \%$ & $50.0 \%$ & $50.0 \%$ & $50.0 \%$ & $50.0 \%$ \\
\hline $\begin{array}{c}\text { Def } \\
13\end{array}$ & $1.2 \%$ & $8.5 \%$ & $16.5 \%$ & $25.9 \%$ & $31.6 \%$ & $32.4 \%$ & $32.4 \%$ & $32.4 \%$ & $32.4 \%$ & $32.4 \%$ & $32.4 \%$ \\
\hline $\begin{array}{c}\text { Def } \\
14\end{array}$ & $0.9 \%$ & $7.4 \%$ & $25.1 \%$ & $33.9 \%$ & $36.1 \%$ & $48.6 \%$ & $48.6 \%$ & $48.6 \%$ & $48.6 \%$ & $48.6 \%$ & $48.6 \%$ \\
\hline $\begin{array}{c}\text { Def } \\
15\end{array}$ & $2.6 \%$ & $6.5 \%$ & $14.3 \%$ & $23.9 \%$ & $35.2 \%$ & $44.8 \%$ & $44.8 \%$ & $44.8 \%$ & $44.8 \%$ & $44.8 \%$ & $44.8 \%$ \\
\hline $\begin{array}{c}\text { Def } \\
16\end{array}$ & $2.0 \%$ & $6.1 \%$ & $10.4 \%$ & $16.3 \%$ & $28.5 \%$ & $32.8 \%$ & $32.8 \%$ & $32.8 \%$ & $32.8 \%$ & $32.8 \%$ & $32.8 \%$ \\
\hline $\begin{array}{c}\text { Def } \\
17\end{array}$ & $2.8 \%$ & $6.2 \%$ & $10.7 \%$ & $27.4 \%$ & $29.2 \%$ & $32.1 \%$ & $32.1 \%$ & $32.1 \%$ & $32.1 \%$ & $32.1 \%$ & $32.1 \%$ \\
\hline $\begin{array}{c}\text { Def } \\
18\end{array}$ & $8.1 \%$ & $11.1 \%$ & $17.6 \%$ & $22.4 \%$ & $32.4 \%$ & $35.2 \%$ & $35.2 \%$ & $35.2 \%$ & $35.2 \%$ & $35.2 \%$ & $35.2 \%$ \\
\hline $\begin{array}{c}\text { Def } \\
19\end{array}$ & $3.3 \%$ & $7.1 \%$ & $11.8 \%$ & $18.1 \%$ & $29.6 \%$ & $32.1 \%$ & $32.1 \%$ & $32.1 \%$ & $32.1 \%$ & $32.1 \%$ & $32.1 \%$ \\
\hline $\begin{array}{c}\text { Def } \\
20\end{array}$ & $3.1 \%$ & $7.5 \%$ & $11.2 \%$ & $17.6 \%$ & $29.3 \%$ & $31.4 \%$ & $31.4 \%$ & $31.4 \%$ & $31.4 \%$ & $31.4 \%$ & $31.4 \%$ \\
\hline
\end{tabular}

Author's own calculation

Table A5.3: Type 2 Errors the Model according to different Crisis Definitions and different Probability Thresholds, Out of Sample Results

\begin{tabular}{lccccccccccc} 
& $\begin{array}{c}\text { Probability } \\
\text { Threshold } \\
\mathbf{1 \%}\end{array}$ & $\begin{array}{c}\text { Probability } \\
\text { Threshold } \\
\mathbf{2 . 5 \%}\end{array}$ & $\begin{array}{c}\text { Probability } \\
\text { Threshold } \\
\mathbf{5 \%}\end{array}$ & $\begin{array}{c}\text { Probability } \\
\text { Threshold } \\
\mathbf{1 0 \%}\end{array}$ & $\begin{array}{c}\text { Probability } \\
\text { Threshold } \\
\mathbf{2 5 \%}\end{array}$ & $\begin{array}{c}\text { Probability } \\
\text { Threshold } \\
\mathbf{5 0 \%}\end{array}$ & $\begin{array}{c}\text { Probability } \\
\text { Threshold } \\
\mathbf{7 5 \%}\end{array}$ & $\begin{array}{c}\text { Probability } \\
\text { Threshold } \\
\mathbf{8 0 \%}\end{array}$ & $\begin{array}{c}\text { Probability } \\
\text { Threshold } \\
\mathbf{8 5 \%}\end{array}$ & $\begin{array}{c}\text { Probability } \\
\text { Threshold } \\
\mathbf{9 0 \%}\end{array}$ & $\begin{array}{c}\text { Probability } \\
\text { Threshold } \\
\mathbf{9 5 \%}\end{array}$ \\
\cline { 2 - 11 } Def 1 & $89.7 \%$ & $81,50 \%$ & $70,40 \%$ & $61,30 \%$ & $50,80 \%$ & $36.7 \%$ & $36.7 \%$ & $36.7 \%$ & $36.7 \%$ & $36.7 \%$ & $36.7 \%$ \\
Def 2 & $83.8 \%$ & $77,70 \%$ & $69,00 \%$ & $57,80 \%$ & $51,40 \%$ & $38.4 \%$ & $38.4 \%$ & $38.4 \%$ & $38.4 \%$ & $38.4 \%$ & $38.4 \%$ \\
Def 3 & $81.9 \%$ & $76,80 \%$ & $68,80 \%$ & $57,90 \%$ & $51,70 \%$ & $39.7 \%$ & $39.7 \%$ & $39.7 \%$ & $39.7 \%$ & $39.7 \%$ & $39.7 \%$ \\
Def 4 & $88.1 \%$ & $80,50 \%$ & $71,00 \%$ & $62,20 \%$ & $58,90 \%$ & $53.0 \%$ & $53.0 \%$ & $53.0 \%$ & $53.0 \%$ & $53.0 \%$ & $53.0 \%$ \\
Def 5 & $91.3 \%$ & $82,80 \%$ & $70,70 \%$ & $60,80 \%$ & $57,40 \%$ & $42.3 \%$ & $42.3 \%$ & $42.3 \%$ & $42.3 \%$ & $42.3 \%$ & $42.3 \%$ \\
Def 6 & $83.2 \%$ & $78,10 \%$ & $69,30 \%$ & $60,60 \%$ & $58,10 \%$ & $49.8 \%$ & $49.8 \%$ & $49.8 \%$ & $49.8 \%$ & $49.8 \%$ & $49.8 \%$ \\
Def 7 & $82.6 \%$ & $77,40 \%$ & $69,10 \%$ & $62,10 \%$ & $58,80 \%$ & $52.1 \%$ & $52.1 \%$ & $52.1 \%$ & $52.1 \%$ & $52.1 \%$ & $52.1 \%$ \\
Def 8 & $86.1 \%$ & $79,80 \%$ & $70,40 \%$ & $62,50 \%$ & $58,80 \%$ & $54.8 \%$ & $54.8 \%$ & $54.8 \%$ & $54.8 \%$ & $54.8 \%$ & $54.8 \%$ \\
Def 9 & $71.2 \%$ & $61,50 \%$ & $56,00 \%$ & $53,00 \%$ & $49,20 \%$ & $40.1 \%$ & $40.1 \%$ & $40.1 \%$ & $40.1 \%$ & $40.1 \%$ & $40.1 \%$
\end{tabular}




\begin{tabular}{|c|c|c|c|c|c|c|c|c|c|c|c|}
\hline Def 10 & $98.9 \%$ & $75,60 \%$ & $55,90 \%$ & $51,90 \%$ & $48,40 \%$ & $30.1 \%$ & $30.1 \%$ & $30.1 \%$ & $30.1 \%$ & $30.1 \%$ & $30.1 \%$ \\
\hline Def 11 & $99.2 \%$ & $76,50 \%$ & $54,00 \%$ & $49,70 \%$ & $50,10 \%$ & $32.8 \%$ & $32.8 \%$ & $32.8 \%$ & $32.8 \%$ & $32.8 \%$ & $32.8 \%$ \\
\hline Def 12 & $76.8 \%$ & $74,20 \%$ & $56,30 \%$ & $47,60 \%$ & $48,30 \%$ & $55.7 \%$ & $55.7 \%$ & $55.7 \%$ & $55.7 \%$ & $55.7 \%$ & $55.7 \%$ \\
\hline Def 13 & $64.9 \%$ & $59,70 \%$ & $55,80 \%$ & $46,50 \%$ & $48,80 \%$ & $34.4 \%$ & $34.4 \%$ & $34.4 \%$ & $34.4 \%$ & $34.4 \%$ & $34.4 \%$ \\
\hline Def 14 & 89.9 & $66.9 \%$ & $58.9 \%$ & $49.6 \%$ & $43.8 \%$ & $35.3 \%$ & $35.3 \%$ & $35.3 \%$ & $35.3 \%$ & $35.3 \%$ & $35.3 \%$ \\
\hline Def 15 & 75.1 & $66.8 \%$ & $58.7 \%$ & $48.3 \%$ & $43.5 \%$ & $34.2 \%$ & $34.2 \%$ & $34.2 \%$ & $34.2 \%$ & $34.2 \%$ & $34.2 \%$ \\
\hline Def 16 & 74.1 & $66.5 \%$ & $58.5 \%$ & $48.1 \%$ & $43.1 \%$ & $31.7 \%$ & $31.7 \%$ & $31.7 \%$ & $31.7 \%$ & $31.7 \%$ & $31.7 \%$ \\
\hline Def 17 & 73.9 & $66.3 \%$ & $58.4 \%$ & $47.8 \%$ & $41.7 \%$ & $31.1 \%$ & $31.1 \%$ & $31.1 \%$ & $31.1 \%$ & $31.1 \%$ & $31.1 \%$ \\
\hline Def 18 & 73.2 & $65.9 \%$ & $48.1 \%$ & $47.6 \%$ & $41.2 \%$ & $30.8 \%$ & $30.8 \%$ & $30.8 \%$ & $30.8 \%$ & $30.8 \%$ & $30.8 \%$ \\
\hline Def 19 & 73.2 & $65.4 \%$ & $51.2 \%$ & $46.7 \%$ & $39.9 \%$ & $29.7 \%$ & $29.7 \%$ & $29.7 \%$ & $29.7 \%$ & $29.7 \%$ & $29.7 \%$ \\
\hline Def 20 & 72.8 & $61.7 \%$ & $50.3 \%$ & $46.1 \%$ & $39.6 \%$ & $29.1 \%$ & $29.1 \%$ & $29.1 \%$ & $29.1 \%$ & $29.1 \%$ & $29.1 \%$ \\
\hline
\end{tabular}

Author's own calculation 